411

p9

920

opy 1

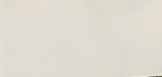

OW TO GROW ROSES

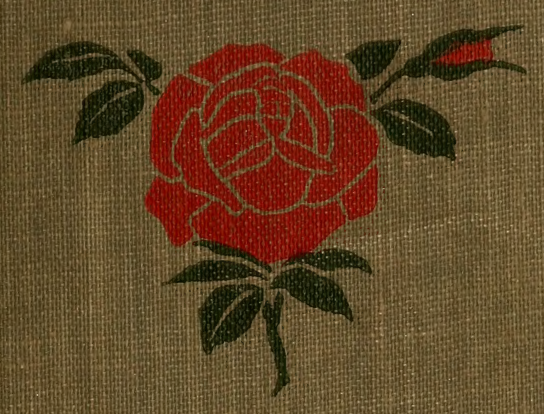

\title{
ROBERT PYLE
}




$$
\text { ชै }
$$






\section{HOW TO GROW ROSES}

DEDICATED BY THEIR PRESIDENT TO THE MEMBERS OF THE AMERICAN ROSE SOCIETY (INCLUDING PROSPECTIVE MEMBERS)

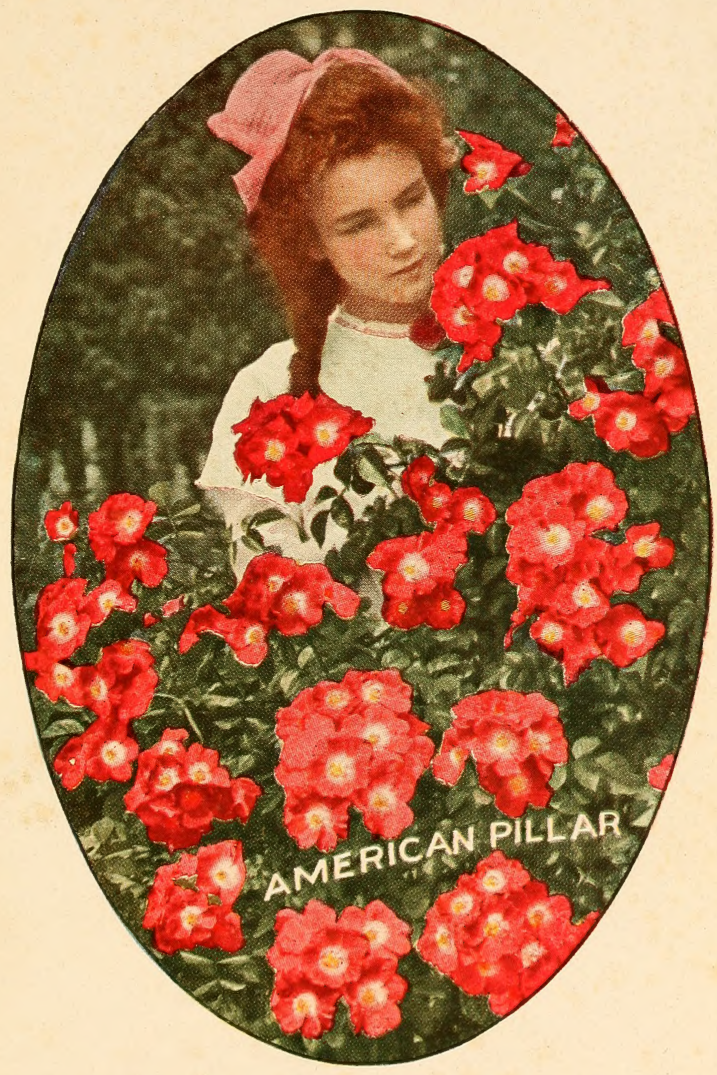

THIRTEENTH EDITION, I920 REVISED AND ENLARGED

By ROBERT PYLE, President

\section{THE CONARD \& JONES CO. WEST GROVE, PA.}




\section{Contents}

The Amateur's Rose-Garden

Establishing Ideals . . . . . . . . . . . . . . . . 5

The Rose-Lover's Calendar of Operations . . . . . . . . 6

Where to Plant Roses . . . . . . . . . . . . . . . . . 9

Preparing to Grow Roses . . . . . . . . . . . . . . . 14

Drainage . . . . . . . . . . . . . . . . . . . . I 4

Soils . . . . . . . . . . . . . . . Is

Fertilizers . . . . . . . . . . . . I6

When to Plant . . . . . . . . . . . . . I7

Treatment on Arrival . . . . . . . . . . . . . . . . . . . 18

Planting .. . . . . . . . . . . . . . . . . . 20

Staking the Roses . . . . . . . . . . . . . . . . 22

Labeling . . . . . . . . . . . . . . . . . . 22

Plotting . . . . . . . . . . . . . . . . . 24

Mulching . . . . . . . . . . . . . . . . . 25

Protecting the Roses . . . . . . . . . . . . . . . . 26

From Frost . . . . . . . . . . . . . . . . . . . . . . 26

From Enemies. . . . . . . . . . . . . . . . . . . 29

Pruning . . . . . . . . . . . . . . . . . . . . $3 \mathrm{I}$

How to Use This Pruning Information . . . . . . . . . 34

Own Root, and Budded or Grafted Roses . . . . . . . . . 36

Selecting the Roses . . . . . . . . . . . . . . . . . . . 37

Family Groups and Abbreviations . . . . . . . . . . . . . 39

Terms Used to Describe Appropriate Uses . . . . . . . . . 4 I

One Hundred and Sixty-two Choice Roses . . . . . . . . 43

Roses for Various Purposes and Uses . . . . . . . . . . 64

Selections for Special Sections of the United States of America . . . . . . . . . . . . . . . . . 77

The Pacific Northwest . . . . . . . . . . J. A. Currey 77

Minneapolis and Vicinity . . . . . . . Theodore Wirth 79

New York and Lower New England . . Rev. E. M. Mills 80

Roslyn and Northwest Long Island Admiral Aaron Ward 8I

Philadelphia and Vicinity .. . . . . . . . Dr. Robert Huey 82

Washington, D. C., and Points South . . Dr. W. Van Fleet 83

Chicago and the North . . . . . . . . . . . . W. C. Egan 84

The Increasing Regard for Roses . . . . . . . . . . . 9i

The American Rose Society . . . . . . . . . . . . . . . 92

Fragrant Roses . . . . . . . . . . . . . . . . . . . . 93

Municipal Rose-Gardens . . . . . . . . . . . . . . . . 95

A Famous Rose-Garden . . . . . . . . . . . . . . . . 98

The Red Rose Church at Manheim . . . . . . . . . . ioo

Rose-Beads . . . . . . . . . . . . . . . . . . IO I

Attar of Roses. . . . . . . . . . . . . . . . . . . 102

Hybridizing. . . . . . . . . . . . . . . . . . . . 104

Bibliography . . . . . . . . . . . . . . . . . . IO5

Synonymous Roses. . . . . . . . . . . . . . . . . . 106

Analysis of Species. . . . . . . . . . . . . . . . . IOT

Roses Arranged in Classes . . . . . . . . . . . . . . ilo

INDEX . . . . . . . . . . . . . . . . I I6 

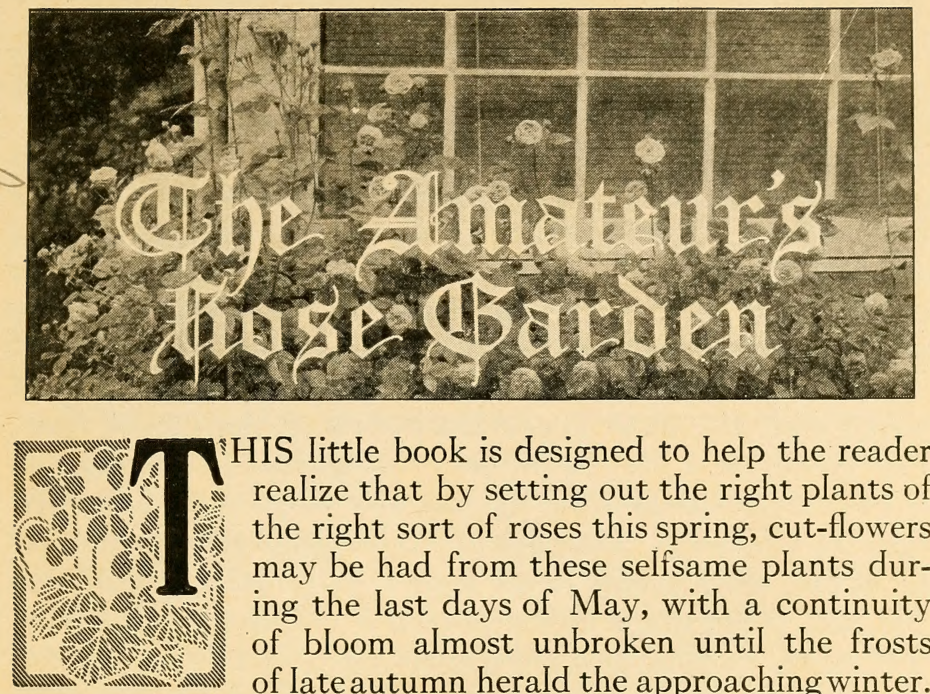

HIS little book is designed to help the reader realize that by setting out the right plants of the right sort of roses this spring, cut-flowers may be had from these selfsame plants during the last days of May, with a continuity of bloom almost unbroken until the frosts of late autumn herald the approaching winter.

Amateurs are now able to have an all-summer "feast of roses," as well as the skilled professional, and it is the amateur's rose-garden, especially, that we have had in mind when writing the following pages.

A large garden is not requisite. Two or three dozen good plants, of the modern and greatly improved sorts, properly selected, will give much enjoyment; while a garden of roses with somewhat greater variety and extent can readily be made a summer-long delight.

In spring, one can have the pleasure of building aircastles about the plants. When the warm days of June arrive, these air-castles will have taken substantial form, and you may go from one plant to another, giving each a little daily attention, contrasting one proud beauty with another equally queenly, and, best of all, gathering an abundance of lovely roses. Half an hour of such tonic-toil each day is a great nerve-restorer, and, what many of those who have tried it realize, it is also food for the soul.

Rose-growing among amateurs in this country is yet in its infancy. In England, before the war, nearly everyone grew roses. Dazzling vistas of roses were to be seen in the 
hedge-rows, along the country roads and Ianes. Gardens were full of flowers, and each person seemed to be striving in friendly rivalry with his neighbor. Why was this extraordinary enthusiasm for the rose? Because it is without a peer among all the flowering plants. It presents nearly every floral shade, in combinations far more attractive than exotic orchids, and, above all, its delicious fragrance gives us the enjoyment of another sense-the crowning feature, in which no other flower can compete with it.

Since history was first written the rose has been associated with the most important events in the life of man. For centuries it has been fully recognized as the Queen of Flowers, honored alike by poet and king. Yet such varieties as Columbia, Duchess of Wellington, and Frau KarI Druschki, the ancients never knew! Why, then, should not you and yours share in the pleasures of the twentieth-century roses, to your own enjoyment and to the advantage of those around you? Just a little garden of these modern wellbred roses; just a little daily, loving care; just a little cost; and the result to you and your neighbors will be the glory of the Queen of Flowers.



The Glory of the Queen of Flowers 


\section{Establishing Ideals}

First consider what kind of rose-garden you will plan. Roses seem to enjoy being arranged in countless ways. Will the frrst show of bloom to burst into view, as one approaches your home, be on your pergola, or arbor, or rose-covered summer-house? If none of these furnishes appropriate setting, probably your banks or fences will be clothed or beautified. A variety of types, shown on the following pages, is available, and choosing from these will become a delight.

Perhaps your fancy may picture prosperous beds, abounding in a wealth of bloom, to be seen across a sweep of level lawn, or from your favorite room in the house, or even hidden beyond the curve in your garden-walk.

The formal rose-garden, too, is important, especially on the larger place. There are excellent reasons why the rose-garden should have a domain all its own. These fastidious creatures that so well repay your thoughtful care may well be grouped and with greater resulting effectiveness. In no other case, perhaps, does careful planning pay so well as in the formal garden.

In these brief suggestions of rose-garden possibilities let us recall vividly the value of the rose in the landscape. Here again a knowledge of varieties is important. Landscape architects are recognizing more and more the noteworthy species which are valuable in mass-plantings for showy effects, for retaining embankments, for bordering driveways, or even for certain types of hedges.

Or you may wish most for a garden of roses from which to cut bouquets, so that "the Glory of the Garden" may be reflected in your home. "Good taste" will suggest the right roses-one for this vase, a bunch for that bowl, a spray for the guest-room, still others for the hallway or the diningroom table, then surely some for boutonnieres, and at times for "state occasions." Surely anyone who has experienced the exquisite thrill welling up in the soul from the presence of choice roses well arranged will be eager to develop the skill needed to make the best use of Nature's garden-gifts. 


\section{The Rose-Lover's Calendar of Operations}

These dates will be found relatively correct for the average season in the latitude of Philadelphia. If you live north or south, make the usual allowance of about four days for every Ioo miles of Iatitude. Comparative altitude must also be taken into consideration. The seasons vary; for example, the ground may be in good condition and ready for digging as much as three weeks earlier one year than it will be the following spring.

March 15.-Such hardy roses as are already planted should now be pruned.

March 25 to 30.-As soon as the ground can be well worked, plant new hardy roses which are to be had dormant. Prune these even more closely than older established bushes.

April 10.-Less hardy roses, including the Everblooming class, should be pruned. Begin to remove the winter protection as the increasing heat of the sun permits.

April 15.- Roses are not immune from mildew and other fungoid contagious diseases; therefore it pays at this time to spray with bordeaux mixture all your rose plants as well as nearby fruit trees and grape-vines.

April 25 to 30.-Finish uncovering and pruning your roses. Plant new ones (now or until the middle of May). A slight shading of these from the sun will prove an advantage.

May I to 10 .- -As soon as plants are well set with foliage, a spraying with a solution of nicotine or sulpho-tobacco soap will act as a preventive against aphides (green fly).

May 20.-As soon as buds begin to sweII, weak manure-water may be applied to the plants. Spray again to kill off the aphides, otherwise they will multiply with amazing speed.

May 25.- Now starts the season's procession of bloom, Ied by the sturdy Rugosas and the Yellow Briar roses. Start feeding the Hybrid Perpetual roses with liquid manure.

June 1 . With this month we see the true glory of the "Feast of Roses."

June 5.-Watch for the rose beetle and rose slug, and spray every ten days for three weeks with a half pound of arsenate of lead to ten gallons of water.

June $10 .-$ Begin to nourish the Teas and Hybrid Teas with liquid manure. (Page I7.) You'Il soon see the result.

June 20 to 30.-Now the Teas, Hybrid Teas, and Climbers begin blooming in abundance. Cut your blossoms freely. Look out for mildew and apply the remedy.

July 1 .-Keep the soil well stirred. A dust mulch at this season is important. 
July 4.-Gather all the flowers you can; it is not best for the plants to have them die on the bushes. You should now be reaping a full harvest from the Teas, Hybrid Teas, etc.

July 10.--From now till autumn keep a sharp lookout for signs of fungoid troubles-such as (I) mildew, (2) black spot, or (3) yellow leaf, and apply bordeaux mixture or sulphur arsenate dust mixture. If any aphides appear, use black-leaf 40.

July 1 5.-Thin out the old canes and trim back all multifloras and other climbers noted under chapter on pruning.

July 20.- Now or earlier mulch your roses with grass-cuttings, old manure, leaves, sawdust, or peat-moss.

August 30.-Teas and Hybrid Teas bring forth their "Fall Flower Show." As soon as the buds form, remember that Bon Arbor or manurewater applied to the roots will help them to produce the blossoms you'Il be proud of.

September 10.-Some Hybrid PerpetuaIs bloom a second time.

October 15.-Make ready your new beds for next year.

November 15.-After the first frost, begin covering the stems of your roses, pages $26-27$, and, soon after this, complete the protecting of the more tender kinds.

Thanksgiving Day.-As soon as the ground has frozen, all should be safely nestled in their winter beds.

\section{WHEN YOUR ROSES ARE UNDER THE SNOW}

December.--Read Dean HoIe's "A Book About Roses." (AIso, see Bibliography, page 105.)

January.-Send for the catalogs of a few reliable rose-growers. February.-Order your new "Made in America" roses.

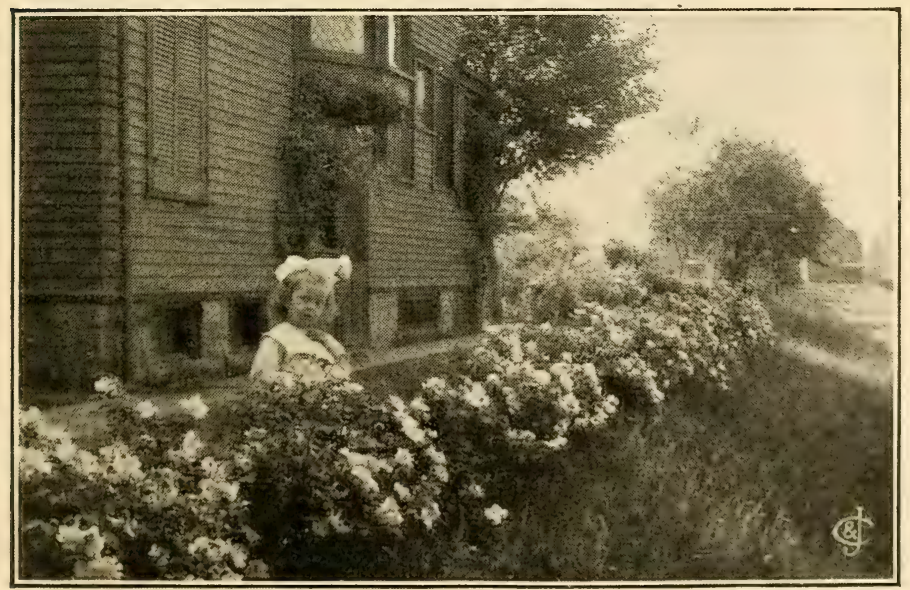

This shows how "York and Lancaster" may be used (page 62) 


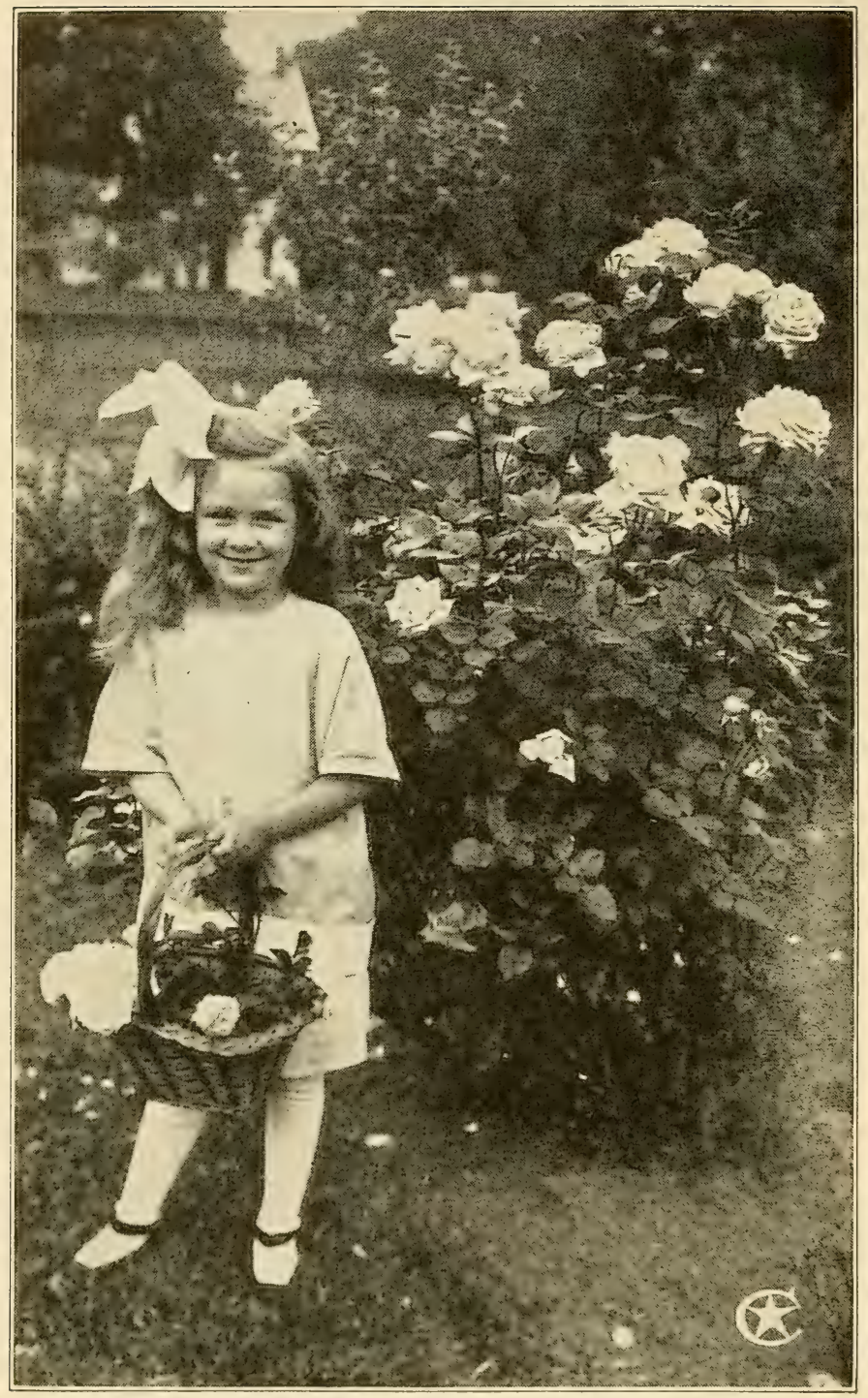

Rival Charmers-both radiate health and happiness 


\section{Where to Plant Roses}

Several available spaces for the rose-bed are usually to be found on the average home-grounds. The author has had the good fortune to visit a number of rose-gardens that are famous-and others that deserve to be - and this may be said of nearly all: that they lay on the genial, sunny side of a generous group of trees or copse, but were open to the gentler breezes, and were not shut in or shaded.

When buying a new property, the selection of the most suitable spot upon it for the house is scarcely more important than the selection of a site for your rose-garden. You will choose a sunny room, if possible, for the indoor nursery, where "the little fairies" in your home may romp and play on a wintry day; and so, too, will you wish to provide for the happiness and well-being of your rose-children, because only a few of them are prairie-born. Only a small section of this large family has been reared to bear the rigors of gusty, sweeping or whipping winds at any time of year, and from such, for the best results, they must be protected. It is not only the severe, cold winds of winter, or the raw, cutting swish of spring, but the hot, withering winds of summer, too, that may ruin the opening buds and spoil the almost ripe fruits of your labor.

Choose a place, therefore, or establish one, protected either by trees, a hedge, a wall, a building, or by some other windbreak. Even a hedge of roses, or climbers, upon a substantial trellis will avail, although a more dense screen is more effective. Choose, too, a place where the sun will shine for not less than one-half of the day, preferably the morning. By this you will see that a space opening away to the south or southeast is to be preferred. We have noted equally successful rose-gardens entirely surrounded by hedges.

Avoid the too close shade of trees, or the proximity of tree-roots; they are ravenous robbers. If the roots can possibly reach over to your rose-beds, they will do it and steal away the nourishment you have provided. Therefore, either keep entirely away from them or, if you must dig your bed 
near them, put in a partition on the tree side to keep back the roots. Boards will do for a time; a concrete wall, about 4 inches thick, will last longer.

Another point to remember is that "roses do not like wet feet." They seem to resent the ignominy of being subjected to standing in undrained ground. Avoid very low ground for this reason, and also because it is more subject to early or late frost, and has greater tendency to mildew.

Try to combine in your choice as many of these conditions as possible, because, while no point is absolute, all are important. Don't stop or give up for the lack of some one of them. Be earnest about it, and you will soon provide the essentials. Mr. Chapman, the ornithologist, asked exPresident Roosevelt how he continually accomplished so much. Mr. Roosevelt answered that this had been his motto:

\section{"Do what you can, with what you bave, where you are."}

That motto will prove most useful for the rose-grower. It lacks, however, one essential, which has been expressed by no other so fittingly, in our estimation, as by Dean Hole: "He who would have beautiful roses in his garden must have beautiful roses in his heart. He must love them weII and always. He must have not only the glowing admiration,

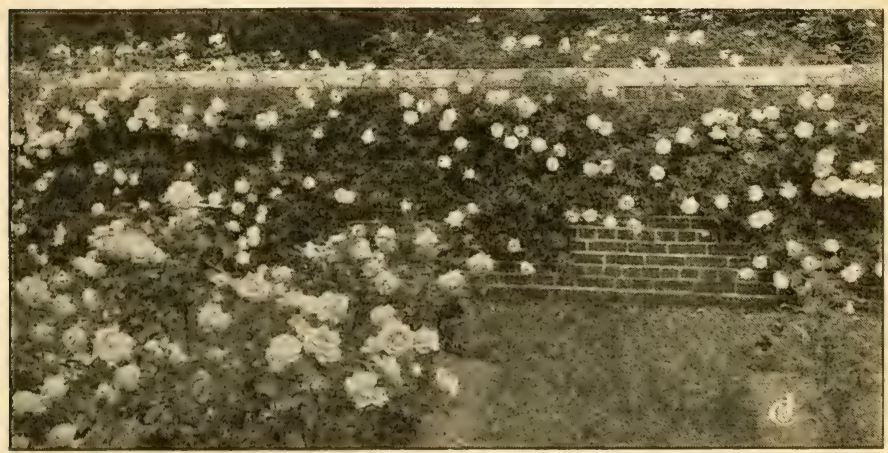

This is Gardenia, running in revelry over the garden-wall 
the enthusiasm and the passion, but the tenderness, the thoughtfuIness, the reverence, the watchfulness of love." The rosarian of beIoved memory understood the secret. And would that we

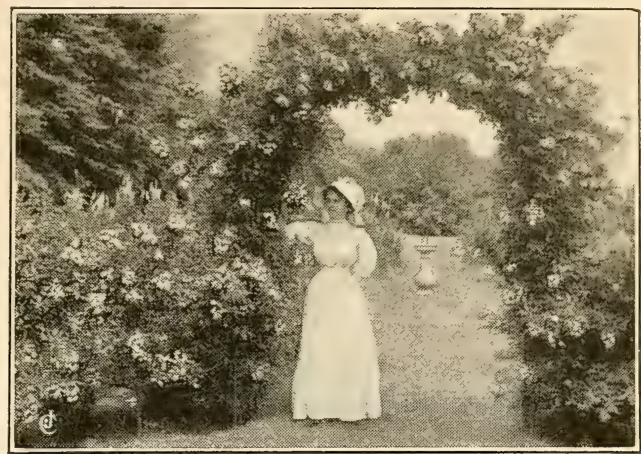

Let climbing roses frame your garden pictures Americans had more, like him, to spread the Iove for beautiful roses, as well as for the wholesome pastime of planting and caring for the Queen of Flowers.

"Make a picture of your lawn." This is the first principle of Iandscape-gardening. Leave open the center spaces and plant about and along the edges. Allow this rule to guide you, then select places for your roses where they will do best and give you the most pleasure.

Some varieties, as for example the Rugosas and the"rose species," serve a very useful purpose when planted among the shrubbery. Many other uses, too, are described on pages 64 to 76 . The bush roses, however, including the Teas, Hybrid Teas, and Hybrid Perpetuals, will prove most satisfying if segregated and not mixed too much with other plants.

The location will help to decide the shape of your bed, and it is mainly a matter of taste as to whether it shall be straight, curved, oblong, round, or square. The essential point to remember is this: You will want to get within arm's reach of every rose in your bed, many times in a year, without stepping on the bed. Not over 5 feet in width and preferably $4 \mathrm{I} / 2$ feet, therefore, is a good rule to follow.

Arrange the roses 18 inches apart each way, unless they are very vigorous growers, in which case allow 2 fect for spread. In warm countries, where the growth is most 


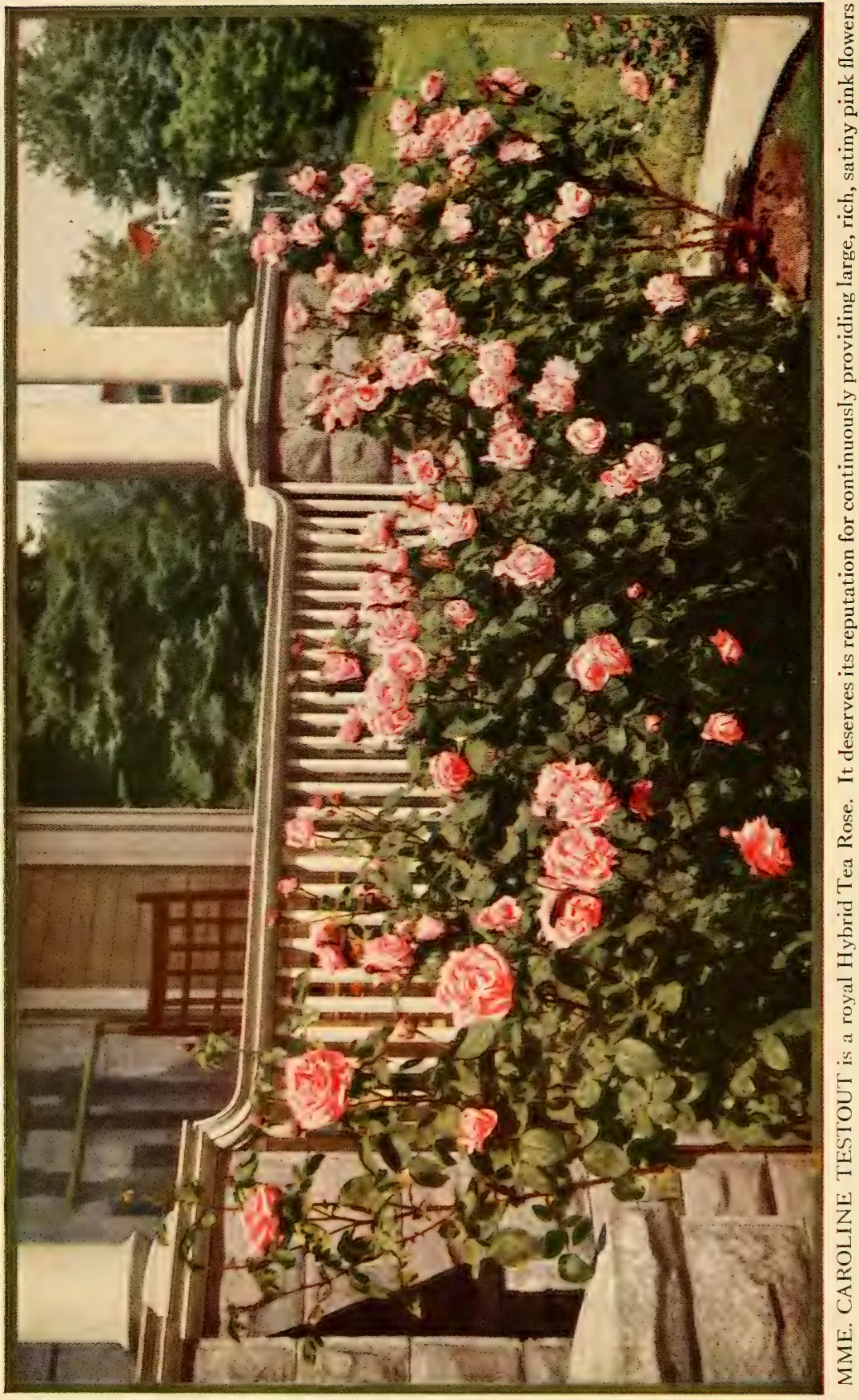


Iuxuriant, and for the big bushy sorts, even more room will be required. Again, there is the other extreme as, for example, in making a border or edging of Polyantha roses, a frne continuous effect may be had by spacing them in the row at only 12 inches apart.

This diagram shows a bed 3 feet wide for two rows. A bed this width, "staggered,"

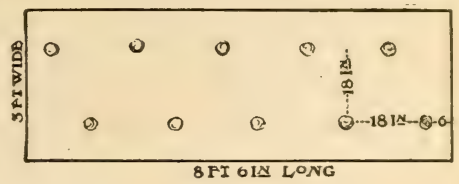

will require twelve roses to every 9 feet, twenty-four roses if 18 feet long, and larger beds in the same proportion.

The young garden in the picture below is well done. Note the avenue effect produced by the double row of Standard or Tree roses on either side of the walk, set from 4 to Io feet apart. They remind one of the beautiful rosegardens in England. Up the wall on either side climbing roses have been started. The front bed on the left in the picture is $4 \frac{1}{2}$ feet square, and contains nine roses. The front bed on the right, if $4 \frac{1}{2}$ feet wide by 6 feet long, would contain twelve roses. The rear bed on the right of the walk is $4 \frac{1}{2}$ feet wide by 13 feet long, and contains twenty-four roses; and the long bed in the rear on the left, if $4 \frac{1}{2}$ feet wide by 20 feet long, would contain thirty-six roses.

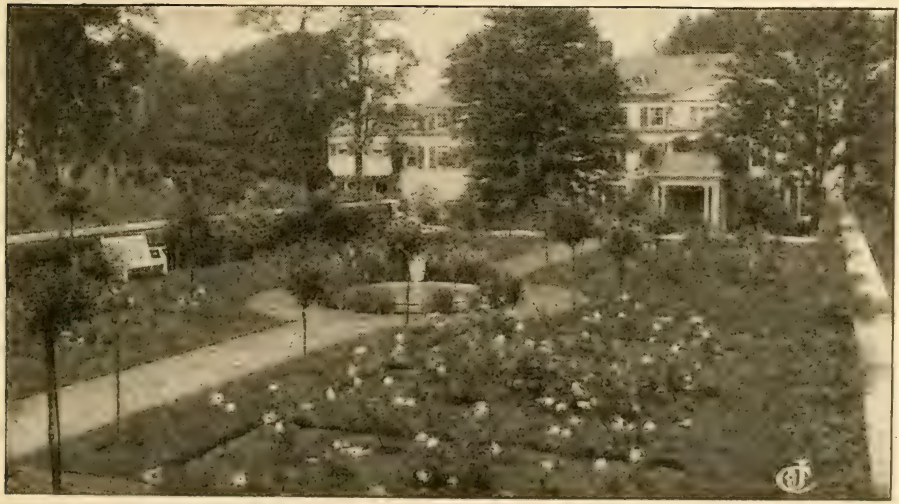

The formal garden is incomplete without roses 


\section{Preparing to Grow Roses}

Having chosen the location and decided upon the size and shape of your beds, you are next ready to prepare the soil. Rev. F. Page Roberts, an ex-president of the National Rose Society of England, has said: "After years of rose-growing in places far apart, I think it is not so much the soil and the climate, as the care and skill of the cultivator that wins success."

A very successful grower of roses in New York State once remarked to a meeting of his rose society: "I would rather plant a 15 -cent rose in a 50-cent hole than plant a 50 -cent rose in a 15 -cent hole." He was wise. The author recalls visiting a successful private rose-garden in New England one day when the roses in one bed were being moved. Those roses had well-developed roots 3 feet long, because the bed in which they were growing had been prepared to that depth, and the top-growth and bloom had been luxuriantly magnificent, testifying to the value of deep and thorough soil-preparation.

\section{Drainage}

One thing, however, must be provided, if you are to court success, that is ample drainage. "Wet feet" for roses are no more conducive to health and happiness than for children. Examine your soil; if there seems a need, provide drainage, and remove the soil from your bed to the very bottom. Place there a layer from 4 to 6 inches deep of stones not larger than your fist, broken bricks, clinkers, or other suitable material

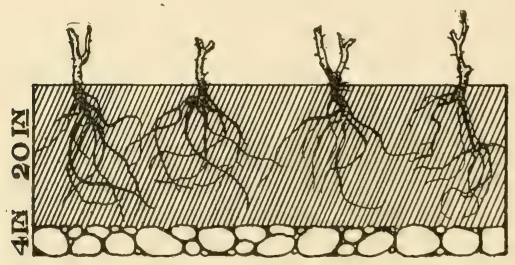

Layers of stones like this are not essential if the ground is naturally well drained that will readily "take" the water from above. The soil is seldom so retentive as to require tiling to take the water away and, indeed, nine times out of ten no artificial drainage at all will be needed. 


\section{Soils}

The good loam so often found directly beneath the sod is excellent, but is greatly improved by being broken, even pulverized, to a depth of at least two spades and thoroughly mixed with about one-third its bulk of rotted manure. Fresh manure must never be allowed to touch the rose-roots. Indeed, the more thorough-going way is to make sure of the nether layer of soil by removing the upper one. First of all, peel off the sod (it will produce excellent compost, see section on "Fertilizers"); next take out the top Iayer of soil to the depth of I foot and pile it nearby. If the soil below that is good, rich loam, or a fair mixture of clay and loam, it may remain. Loosen this with a garden fork to a depth of another foot, preferably not upturning it, and mix with it well-decomposed manure, and then put back the top layer of loam in which to plant your roses.

If, on the other hand, you find the subsoil poor, barren, and unproductive, you may have to remove it altogether. Haul it away, and put your chopped-up sods in the bottom, grassside down, to rot and make future plant-food. If you have ready from the previous year a compost made by mixing onehalf or two-thirds of sod, with the balance of manure from the cow-stables, use it in the bottom of your bed, and make a future storehouse of rich nourishment for your roses.

Another hint: A few broken bones may be mixed with the soil in the bottom of the trench, say a peck for a bed holding a dozen roses. These will decay slowly, and furnish plant-food for three or four years to come.

Not all roses like the same soils. The Hybrid Perpetuals, for example, love a heavy clay or loam. So do the heaviergrowing climbers; whereas the Teas, Hybrid Teas, Bourbons and the like, revel in a lighter soil and a warmer one, with less than 50 per cent clay or loam, and more sand or leaf-mold. Rugosas thrive even in quite sandy soil.

"It is difficult to give the roses too rich soil." If your soil is light and sandy, and you cannot well replace it entirely, it may be greatly improved by mixing a little clay or rich loam 
with it when trenching. If your soil seems too heavy, it can be made lighter and more open by adding sand, or even coalashes: To be good for roses, the soil must be such as will not quickly transmit to the roots sudden surface changes of temperature. The roots should be kept cool. If it be possible after the soil in your bed has been prepared, give it time, say two or three months, to settle before planting your roses. If this be out of the question, press with your feet each layer of soil in your bed, as you proceed to fill it in.

\section{Fertilizers}

While manure from the cow-stable is best, you can draw upon the horse-stable, sheep-pens, or pig-sty with expectation of good results, and "night soil," mixed with dry soil, or sand, and well composted is excellent. WeIl-rotted leaves are fair, but too light except for heavy soils. Commercial fertilizers, such as ground bone or guano, may be used with advantage if handled with discretion. A rule to remember is never to let any "green" or "raw" manure come close to the roots of your roses, but see that it is buried well beneath the root reach, or applied as a top-dressing. After your roses have been planted, the best time to apply manures is just as the ground begins to freeze in the autumn. Let it serve as a protection over winter, and dig it in next spring, being careful, however, not to disturb the roots.

Far better than surface-coating is the ample supply of fertilizer placed weIl under the roots in the bottom of your beds, before you plant your roses, because roots travel toward their food-supply. By thus enticing them downward, you develop a strong, deep root-growth down into the reservoir of stored-up food and moisture, so that, when dry weather comes, they will not hunger and thirst, as they would with only surface roots. Surface application of manure-water is quite a different matter, as that will percolate down to the deepest roots.

It is said that roses draw most upon the soil when blooming, and we find you can almost see the results from application (when the flower-buds begin swelling) of liquid manure, 


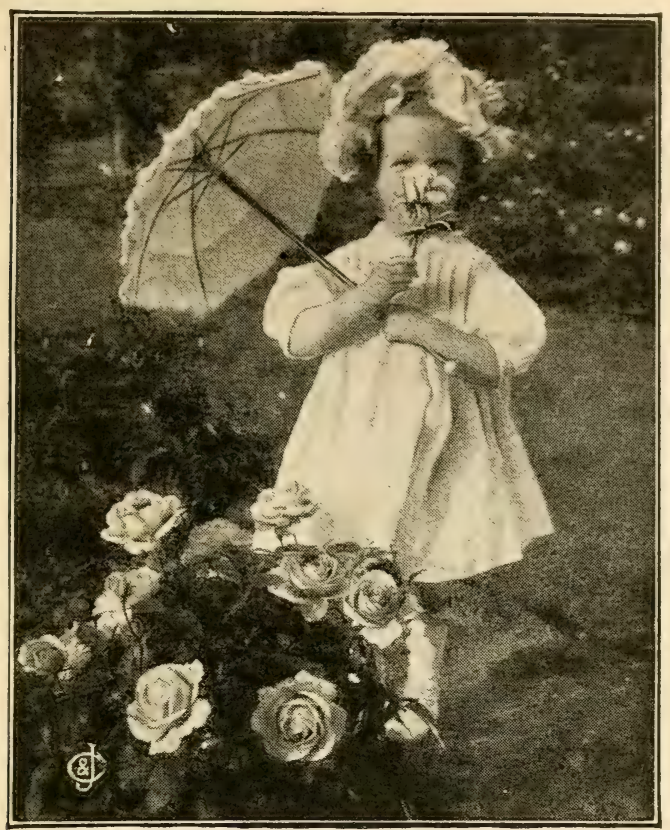

Nearly every child is fond of flowers

concocted by catching the drain from the manure-pile, or one-third of a bushel of manure in a bag and soaked in a barrel of water. Apply this as a weak tea, not too strong, but frequently, say twice a week. When it is more convenient, a sprinkling of bone-dust on the surface before a rain will answer the same purpose. Even with the best care, it may prove necessary in some locations, say after six or eight years, to renew the roses or move the bed, adopting the farmer's principle of rotation of crops.

\section{When to Plant}

Tell us where you would grow roses, and we will tell you when to plant them. The most carefully laid down dates for New York State are "null and void" in New Orleans. Proper * planting-time in the same state may vary according to differ- 
ences in altitude and latitude. Where the winters are not too severe, as in our GuIf and Pacific Coast States, and the

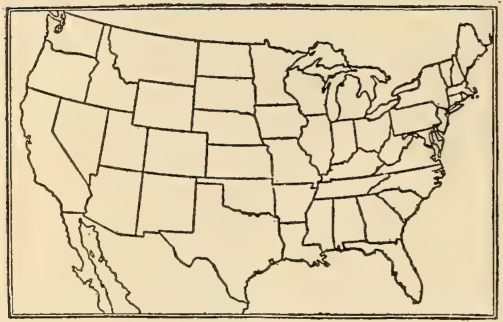
next tier of states north, autumn-planting is to be preferred.

North of the line of the Ohio River, only our hardier varieties, such, for example, as the Hardy Climbers and Hybrid Perpetuals, Rugosas, Moss and Pernetianas, will withstand the first winter out, if autumn-planted.

As a matter of general practice, there are, doubtless, ten times as many roses planted in spring as in autumn. For the latitude of Philadelphia, dormant roses should be planted as soon in spring as the soil is dry enough to crumble in the hand, and plantings may continue till midApril. Growing roses from pots should not be set out until danger from frost is past, usually the last week in April. If you live north of 40 degrees latitude, defer planting from this date by one week for every hundred miles. Do not attempt any planting operations with the ground frozen, or the thermometer below 45 degrees Fahr. Roses from pots, when shipped with soil on the roots, may be planted at any time through the growing season, even during the summer.

\section{Treatment on Arrival}

Think of your roses as living creatures, even though they be asleep (dormant) when you first get them. Unwrap them with the greatest care; never expose the roots to the drying action of the spring winds for a moment. A plant with bare roots exposed to the dry air is like a fish out of water. Untie the bundles so as not to break, bark or bruise either root or branch. Should the plants, through delay in transit, come dried out, as occasionally happens, soak the balls of earth and roots in water; if the stems also have dried out, bury the whole plant in damp earth for three or four days till the 


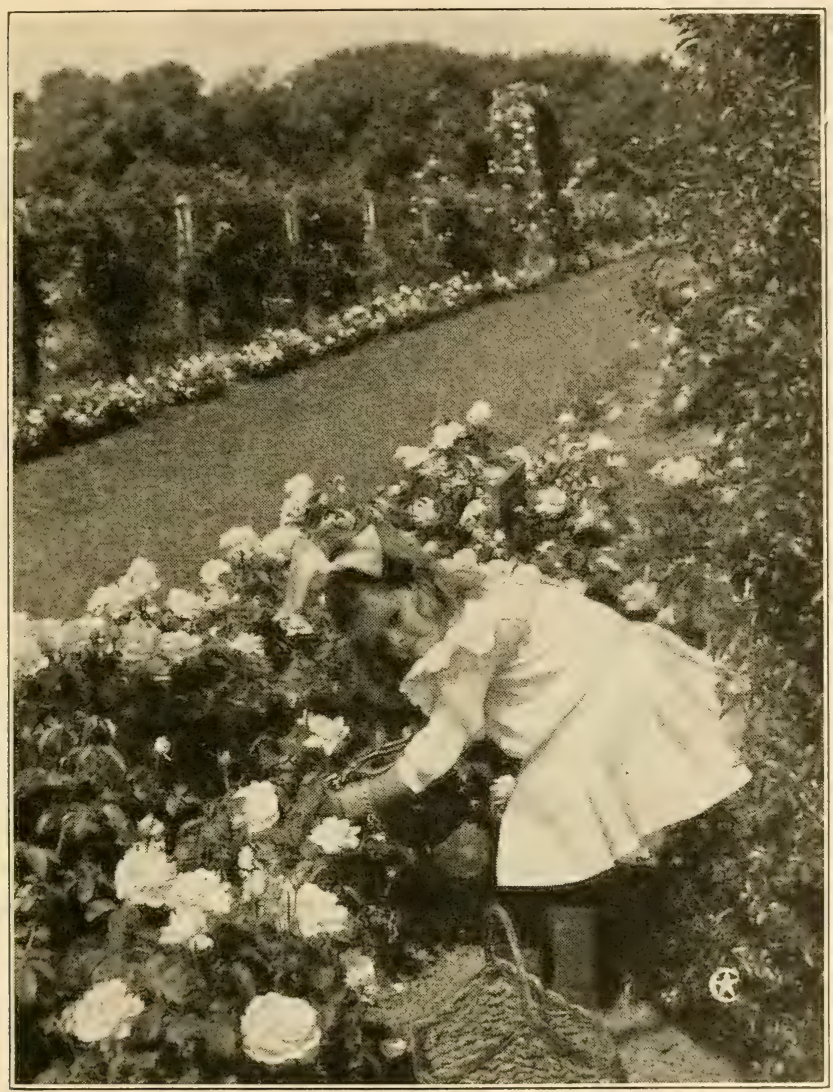

When this little girl grows up and has a garden of her own, she too will know how to grow fine roses.

shriveled branches regain their natural plumpness. If you cannot plant the roses when they arrive, "heel them in" in the garden until you are ready to plant them. This is done by digging a trench deep enough thoroughly to cover all roots and even lower branches of each bundle of roses. It will be better to untie the bundles so that the roots can be more thoroughly covered. Press down this soil-cover firmly. 


\section{Planting}

When ready to plant, remember again that roots must be kept from the wind. Spring winds are so drying that fatal damage may occur from a few minutes of exposure. The best plan, when planting, is to keep the roots covered with a damp piece of burlap, or of other packing-material.

Next make the holes in the bed, which should have been prepared as shown on page I5, and make them large enough to accommodate the roots in a natural and uncramped position, neither too deep nor too shallow (see illustration). Do not spread the roots out flat, but point them down, slanting outward. Use care to keep the roots from direct contact with the manure, lest the roses get indigestion. It is a good plan to dip the roots, before planting, in a thin mud made by mixing Ioam or clay with water. Settle well-pulverized soil in around the roots, so as to fill up every air-space, and so that every single root shall be entirely encased in soil. When the hole is half-filled, and roots covered, press the soil down frrmly with the hands; then fill the hole with water, and let it drain away; fill in level with soil, and tamp it carefully but securely; then give a frnal covering of soil, which should be about level with the surrounding turf, but not high enough to let the water run away when it rains. Also protect from the bright sunshine for a few days.

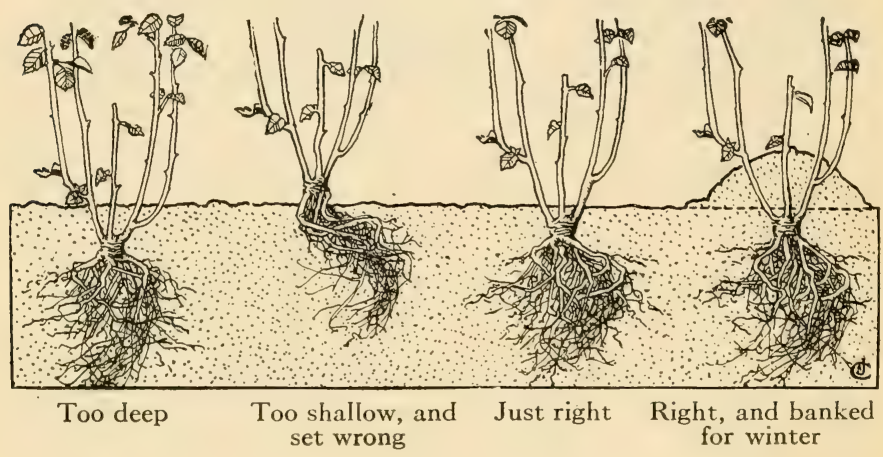




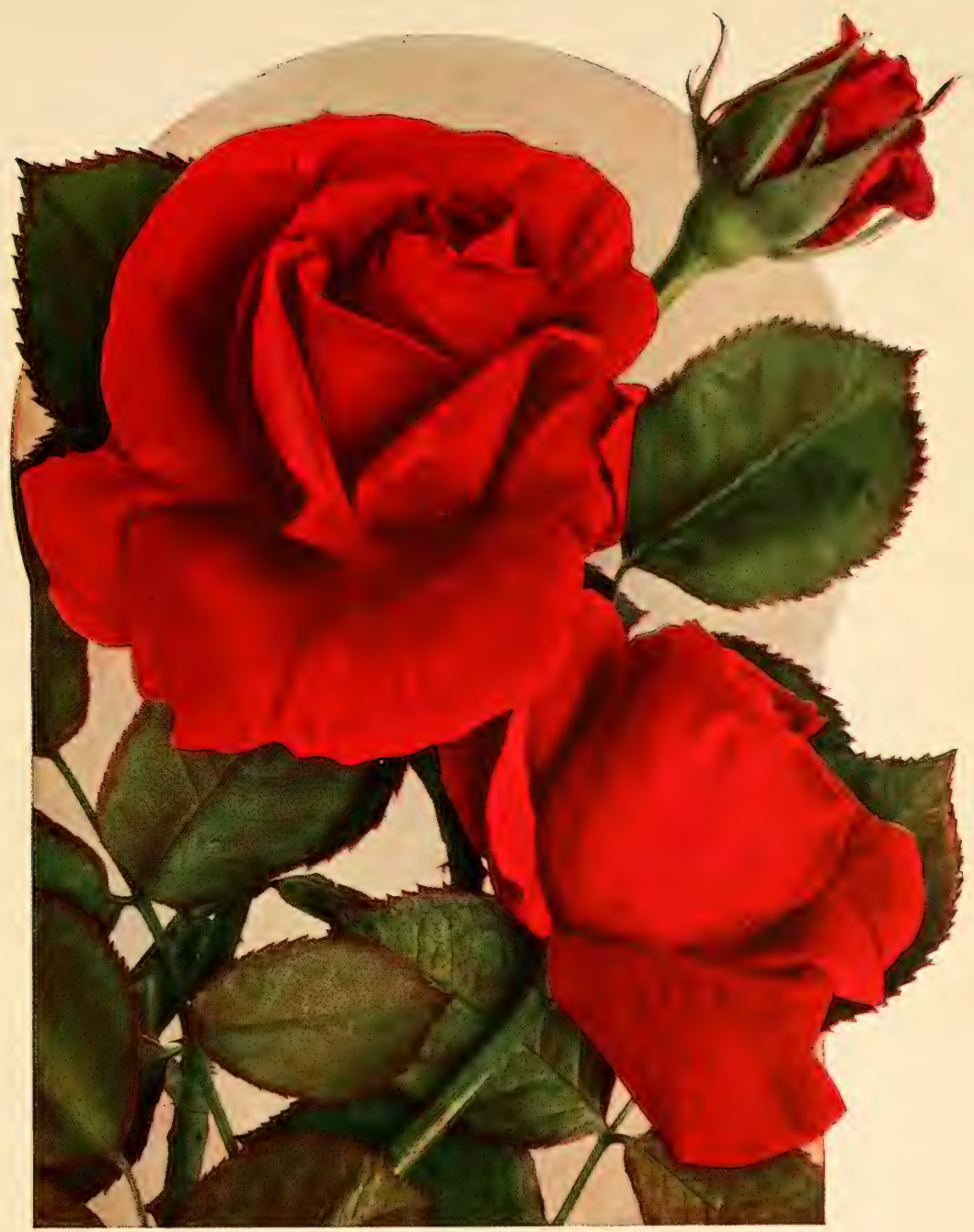

For splendior, beauty and impressiveness the red Rose stands preëminent, and among the Hybrid Perpetuals the J. B. CLARK, shown above, is a variety with real merit.

Among the more recent introductions in this class should also be mentioned Hugh Dickson, George Dickson and Gloire de Chedane Guinoisseau.

Can you imagine any flower more exquisitely appropriate, either worn singly or in display for the most important occasions, than a freshly opened bloom like the above?

Important celebrations and state occasions are coming more and more to depend upon the Rose for its decorative value, satisfying the mind and heart, as well as the eyes, of all observers. 


\section{Staking the Roses}

Standard or Tree roses, unless extraordinarily sturdy and planted where they are protected from the winds, will be the better for staking. The stake should come well up to the head of the rose. Place it while planting, for if it is driven Iater it may injure an important root. Bush roses seldom need staking when planted, although this is a matter for attention according to the needs of individual varieties. Plants should never be permitted to sway about or become loose at the collar. If the sun be warm within the next day or two after you plant, the bush will be the better for being shaded, as well as for mulch about the roots.

\section{Labeling}

Rose-growing with Iabels is by far the most delightfuI kind. You lose half the pleasure if you lose the names, to say nothing about the satisfaction of accumulating information. The importance of labeling is really great. Do it when you plant as a part of the operation; otherwise, it is likely to be overlooked. The growers' labels are not likely to last more than one season, and then it becomes dreadfully embarrassing not to know what to call your plant-children, whether you want to scold or caress them. Choose the label with fewest faults.

\section{Copper Labels}

These are made of light sheet copper, eyeleted and wired ready to use as soon as the name of the plant is inscribed. The copper labels are very light, and are therefore most suitable for hanging on the branches of your roses in a conspicuous place, not to be disturbed until you begin your pruning. Then, if necessary, remove them to some other part of the plant not in danger from your shears. But any type of label that must be wired on the bush may constrict and check the life of the stem or branch on which it hangs. Therefore, a better way 
to use these copper labels is to suspend them on a stout wire stake alongside the plant, so that no removing will be necessary unless the rose is being transplanted to some other part of your garden, when, of course, the label should go along with it. This shape of label is now available in celluloid faced with perfectly transparent mica. (See right-hand cut at bottom of page 22.)

\section{Plain or Printed Wooden Labels}

Plain or printed wooden labels, similar in size and shape to the two illustrated on page 22, may be attached to an upright iron stake (such as is here shown). This is the scheme followed by Capt. Geo. C. Thomas in his noteworthy garden near Philadelphia. Furthermore, upon the same stake, with the name label, he hangs a plain wooden label which is used throughout the season on which to mark the number of roses harvested from that bush each time one or more is cut. Such a plan, faithfully followed, makes an invaluable record for any careful rose-grower.

The best of wooden labels must be sometimes renewed.

A more permanent type we call the Garden Club Label. It is a triangular piece of flat zinc with rounded corners, hung on the gooseneck top of No. 9 galvanized iron wire, 15 inches long, as above. There is room on the reverse side for date of planting and other data. For indelible ink, dissolve a copper cent in a I-ounce solution of one part sulphuric acid and five parts water; or, if preferred, paint the label and stake green and the letters in white. This label keeps clean because it is above the mud-splash of the raindrops.

The Mann Plant Label hereby illustrated is of zinc. It is practically indestructible and stays put. The size is $9^{1 / 2}$ inches long by $3^{1 / 4}$ inches

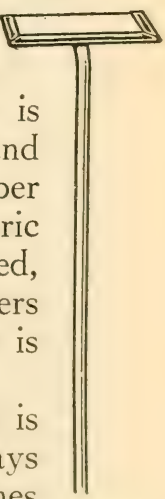

Simplex Label 
The Simplex Labels illustrated on page 23 are a single piece of metal frame and stake 16 inches long and securely hold in place a slightly roughened celluloid card which is protected from the weather by a clear, smooth cover of mica.

Celluloid labels, with the rose name printed in and clearly showing from beneath a transparent glazed surface, are perhaps the most recent development and promise great satisfaction.

The most elite rose labels we have ever seen were those used by M. Gravereaux, at L'Hay, near Paris, where, on top of small, sturdy, iron stakes, were bolted beautifully finished, flat top, oval name-plates of porcelain.

\section{Plotting}

But the "best Iaid" Iabels sometimes go wrong, and in some unexplainable fashion do get lost; therefore, to be entirely protected, you can take out Iabel insurance. Some people think this is more important than Iabeling. Draw a diagram of your bed, and then with letters or numbers indicate on it the location of each rose. With this make out and keep a key-list of roses lettered or numbered to correspond with those on the diagram. We venture to predict that such a list will prove its value before the end of the second year.

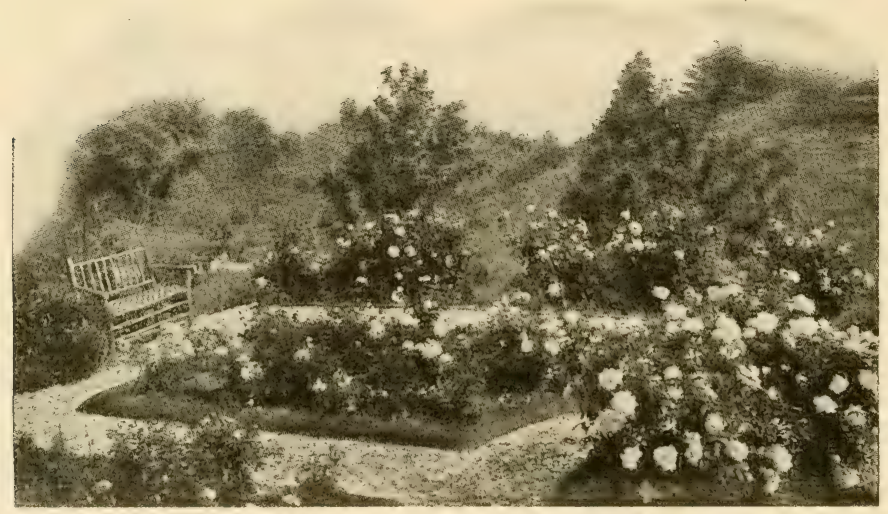




\section{Mulching}

There is a treble object in this: First, to retain the moisture; second, better to preserve a suitable temperature in the soil; third, to stop weed-growth. What is called a "dustmulch," maintained by frequent hoeing, is, perhaps, the best method, although, where the summers are warm, a covering in early July of long "strawy" cow-, pig-, or horse-stable manure that will not heat, will accomplish the same object. The lighter and more chaff-like portion should be removed in the spring and the richer part dug in. Peat-moss we look upon as even better than a manure-mulch, because the Iatter may encourage root-growth nearer the surface than is desirable. We have also tried sawdust for covering the beds in summer. It certainly prevented need for weeding and otherwise seemed beneficial. Another plan is to plant some low-growing and shallow-rooting ground-cover plant, like violas (pansies) or portulacas. These grow quickly from seed and should be established by mid-July.

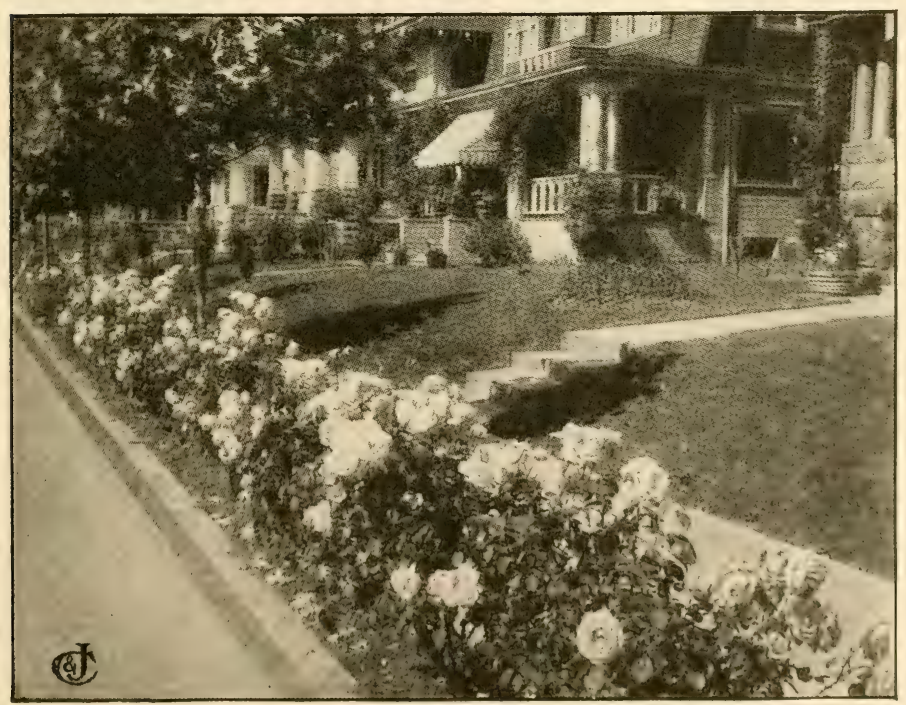

Roses where everyone may enjoy them 


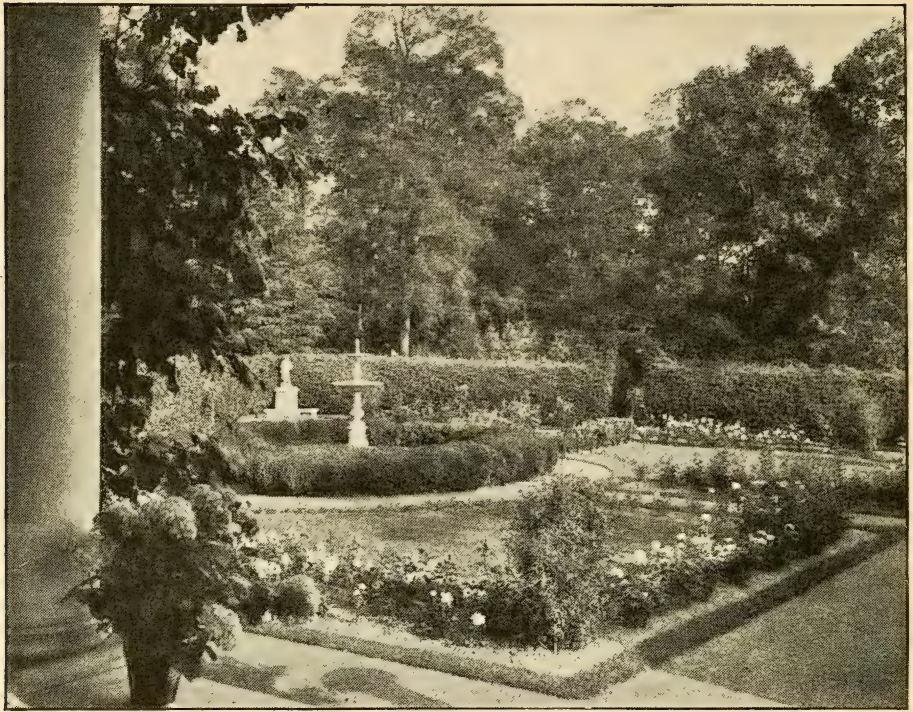

Roses in the outdoor living-room

\section{Protecting the Roses From Frost}

W. C. Egan, the eminent horticulturist of northern IIlinois, succeeds admirably in keeping his roses over winter, as does also the Superintendent of the McCormick estate; and yet, north of Chicago, where they live, the severe winters and the cold winds blowing over Lake Michigan, often kill the Wichuraianas and Rambler roses to within a foot of the ground, when not protected. An eminent judge, living north of Detroit, by the work of his own hands, protects his Hybrid Teas so that they triumphantly weather zero winters. On the famous shore-front at Newport, Rhode Island, we found the tender Gloire de Dijon rose, which we had supposed could not be grown north of Washington, D. C., green and thrifty to the second story, after a most severe winter season. But the protection had been very thorough. 
Obviously, there is no danger where there is no frost. Where the thermometer falls below freezing, the less hardy varieties should be partly covered, and all roses will be the better for some protection, at least about the roots. If you are visited with zero weather, let "preparedness" be your rule. To begin with, bank up the soil cone-shaped, with the apex 6 to io inches high around the stem of each bush. Ashes are sometimes used, but nothing we know of is better than soil. In very cold countries, the roses may be lifted entirely and buried in trenches for the winter, and they will come out in fine shape for replanting in spring. After you have drawn the soil nicely around them (see calendar), leave them alone till the ground is frozen with a crust hard enough to bear the weight of a stone-laden wheel-barrow. By this time the moles or mice, or other creatures, will have secured their winter abode elsewhere, and not be tempted to make nests in the protecting material you will next apply. Now do not smother your roses, or they may die. Cover them thoroughly, as high up as you attempt to protect them, but always allow for the circulation of air. A 3-or 4-inch blanket of good, heavy stable-manure will keep out much cold. Over this fill up from the bottom of the bed to a depth of 10 or 12 inches with nice, dry leaves, and with some light material on top to keep them in place. A I2-inch fence of poultry-wire staked round the bed will help keep the leaves in place. The boughs of fir or pine trees, hay, straw, or cornfodder, or other material that will break the force of cold, biting winds, will serve in place of leaves, and where most careful protection is required, boards may be arranged roof-fashioned to turn off the rains. This will also protect your roses from exposure to direct sunshine when nights are freezing-cold, and avoid alternate thawing and freezing, which is dangerous, and in early spring prevent the premature excitation of plant-growth and tender buds. For this reason, too, remove protection in spring gradually, and not all at one time (see calendar, page 6).

A method that has proved successful in one of the coldest sections of the United States is thus vividly described: 


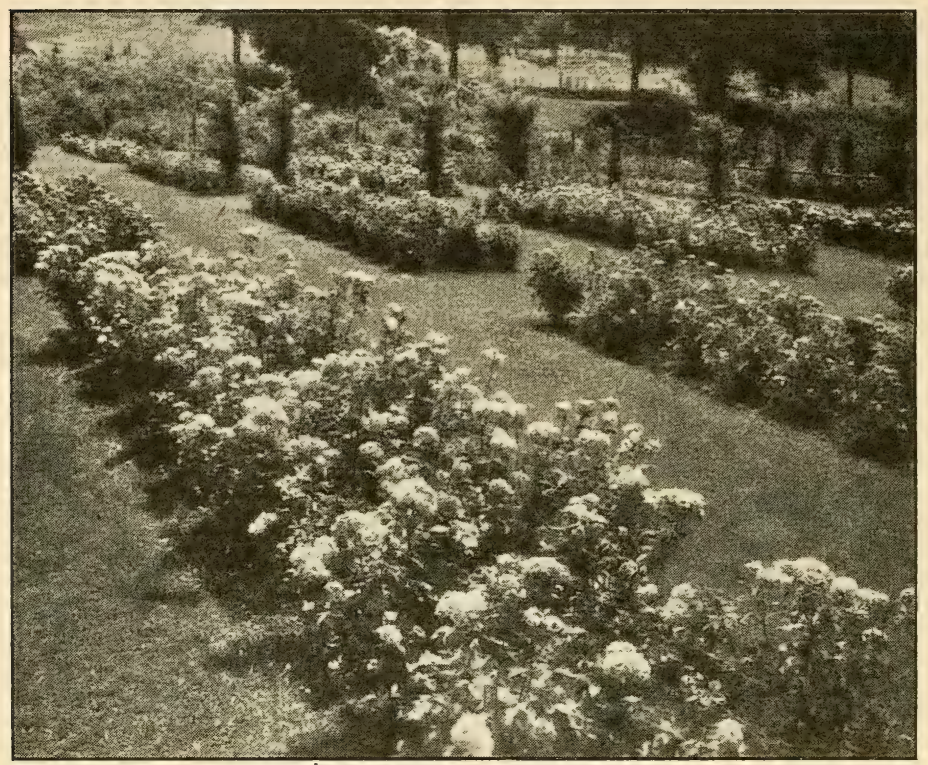

Minneapolis MunicipaI Rose-garden

*. . Our principal problem would be to provide proper winter-protection. We took special pains to ripen the wood. We stopped watering and cultivation in September, and discouraged late growth. The last week in October we gave the beds a very thorough soaking, and a few days after we tied the shoots close together, and piled the soil around the plants as high as we could with material taken from between the plants, so covering from four to six of the lower eyes. The garden was then left in this condition until there were 3 or 4 inches of frost in the ground. We then filled in with dry leaves, gathered from the nearby woods. The leaves were thrown in loose and not packed down, and covered the beds to the height of the soil heaped around the plant. We then boarded in the long sides of the beds 2 feet high, and boarded over the top of the bed, but left the two ends open. Over this board cover we spread a layer of bedding, straw and hay. 
"It will be seen by the method of winter-protection herein described that our aim was to prevent, if possible, thawing after frost had set in; to protect the plants from the drying effects of the strong winds, without preventing the free circulation of air. We have employed the same method of protection ever since, and generally we have been successful in bringing the plants through winter in very good condition." (Article, "The Minneapolis Municipal Rose-garden in Lyndale Park," by Theodore Wirth, in "The American Rose Annual," I9I6, pages 79, 80.)

Protecting Tree roses over winter is most important. Set up a box about 2 feet square, and high enough from the ground to encase the head, and fill this with soil to cover all but the topmost branches. No part needs protection more than the point where stock and branches join. Another method is to loosen the earth on two sides of the plants so they may easily be bent over without breaking anything and then, when staked to the ground, cover with 6,8 or more inches of earth till danger of frost is past in spring, when they may again be reinstated and restaked. In some locations it may prove quite as convenient, and equally effective, to take up the plants entire, and bury them in a trench in the vegetable garden.

\section{Protecting Roses from Enemies}

Eternal vigilance is the price of perfect flowers, because "prevention is better than cure." Vigorous, healthy plants are seldom troubled much.

The two golden rules to remember, says Mr. Edward Mawley, one-time President of the National Rose Society of England, are these: "Keep sharp watch out for the first appearance of insect or fungoid pests and adopt measures for destruction at once. Then persevere with the remedy adopted until a cure has been effected."

Our Lady Rosa likes cleanliness above all things, and will respond generously to these attentions. Keep your roses clean and healthy and they are almost certain to be happy. 
The beginner need not be dismayed at the array of troubles that may happen; if they do, these hints are offered as a "first aid." As a matter of fact, not all the pests are likely to appear in the same garden. Rose-growing is not so complicated or difficult as might appear.

\section{Insects}

Probably our worst enemy to roses is the Rose Chafer ("Rose Bug"), which is particularly severe on sandy soils. For this, handpicking into a vessel of kerosene is effective, or, as a preventive, spray every two weeks through June and July with bordeaux mixture ( $\mathrm{I}$ ounce to $\mathrm{I} / 2$ gallons of water) or a solution of $1 / 2$ pound of arsenate of lead in 12 gallons of water. This is also a good remedy for the Rose-SLUG, which skeletonizes the leaves. It works from the under side of the foliage so when going after it, turn the foliage down side up and spray it thoroughly.

Aphides, or Green Flies, attack the plants during May and June, and, if not dispatched, they multiply rapidly, and suck the life-blood from the leaves. A vigorous spraying of black-leaf 40 or whale-oil soap will settle them. Scale seldom bothers any except old, neglected shrub roses. Use scalecide or lime-sulphur wash.

\section{Diseases}

Of the fungous diseases, Powdery Mildew is by far the worst and most difficult to overcome. It will be recognized as a white mold appearing on the foliage, which, if not checked, will spread.

This is most likely to occur in warm, damp weather, and certain varieties, such as Crimson Ramblers, are more subject to its attacks. Bordeaux mixture, applied at fortnightly intervals, is a good preventive (see formula above). Even better, use sulphur arsenate dust mixture. Formula: Nine parts frnely powdered sulphur to one part arsenate of lead. Apply with a dust gun. For Black-Spot, Rust, and other fungous diseases, follow the same course. Also promptly remove and burn foliage thus affected. 


\section{Pruning}

If you have bought two- or three-year-old plants, cut them back rather severely at the time of planting - to three or four buds on the Hybrid Perpetuals and about six on the Teas and Hybrid Teas. Always cut the stem just above a bud that points out, never above one that points toward the center of the plant. The term bud or eye is used to define the places on the stem where leaves will be produced. They are easily distinguished, as they look like small, pointed warts on the stems. If the plants are in leaf when planted, the above does not apply. The crop of flowers on the rose plants is largely governed by the kind of pruning the plants receive. In fact, other conditions being ideal, the pruning determines the quantity and the size of the flowers.

The Hybrid Perpetuals and most other hardy roses should be pruned in March; if weather permits, by the

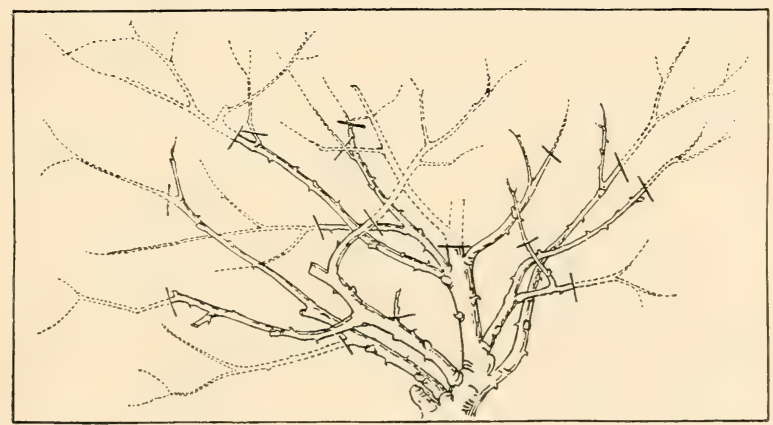

Method of pruning Hybrid Teas for garden display

(As recommended by the N. R. S. of England)

middle of the month. The tender roses, the Teas and Hybrids Teas, need not be pruned until along in April, when the sap begins to flow and the buds begin to swell; for, at this time, dead and weak wood may be much more casily distinguished and cut out than earlier in the season. Besides, it is an advantage to leave the mulch undisturbed until settled weather has arrived. At the time of pruning, one must 


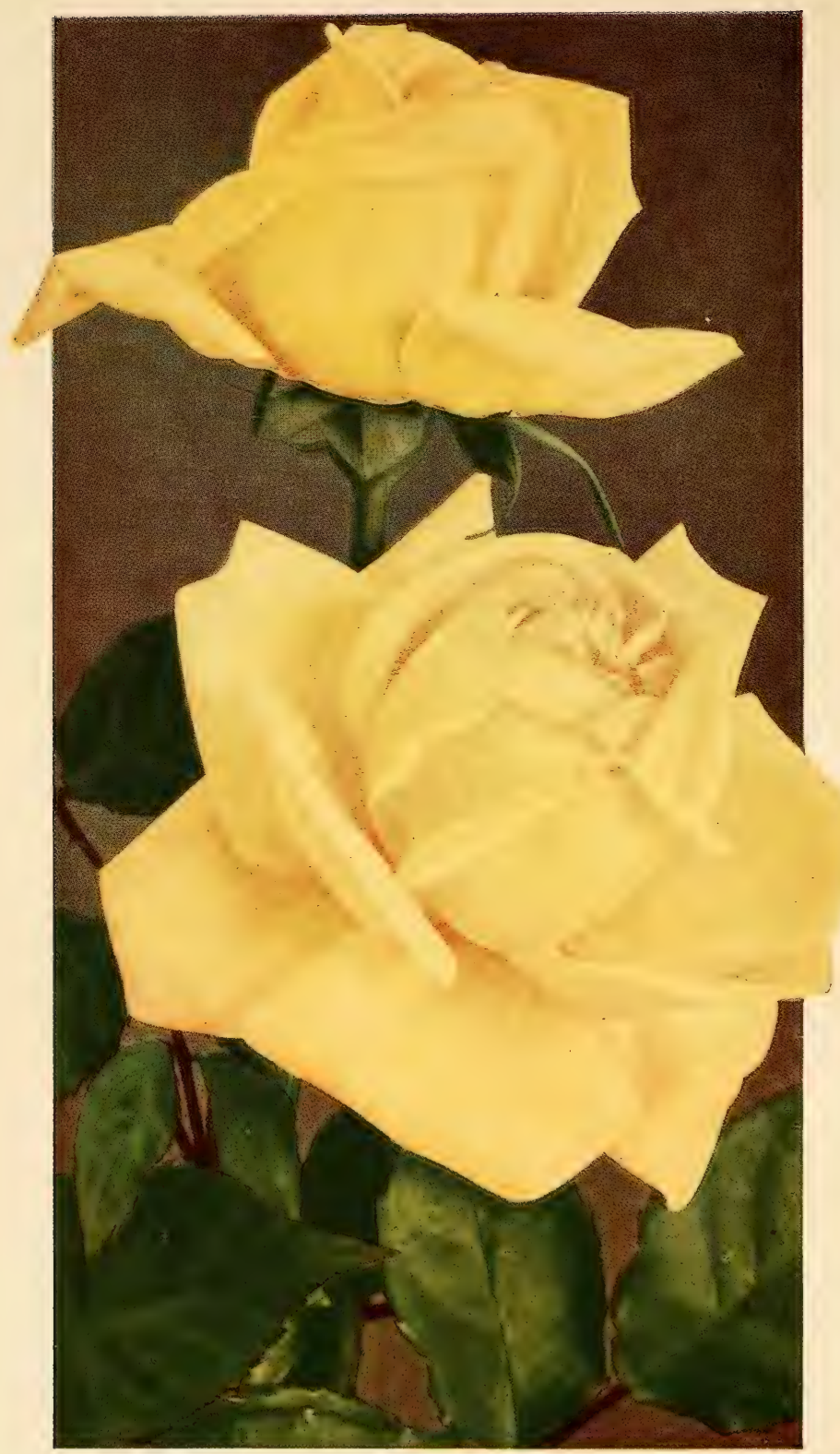

The PERLE DES JARDINS is a standard Tea Rose of rich golden yellow color and fine form; it blooms freely on strong stems. Other newer Roses of related color and great merit are Lady Hillingdon and Alexander Hill Gray. 
decide upon the kind of crop wanted. If the very biggest and best flowers are wanted, severe pruning is necessary (see I, page 34); if a large crop of average flowers, only moderate pruning (see 2, page 34); but, where a quantity of bloom is preferred, only a little pruning is necessary (see 3, page 34).

When pruning Hybrid Perpetuals, first cut out the weak wood and any branches that cross; then cut back the strong canes to about six eyes, the top one pointing out, and the cut being made one-quarter of an inch above the bud. If you want only a few big flowers, cut back to only three or four buds. For the big outdoor display, leave four to seven canes twothirds their growth. The Teas and Hybrid Teas will need the same attention, but there should be as much or more wood left. In case the winter may have killed the canes, cut back to live wood, even if down to the surface of the soil.

These rules are modified somewhat by the character of the plant. The weakergrowing varieties can be cut back farther than strong-growing sorts. The strong-growing kinds, if cut back too heavily, will run to wood, and, in the case of some, too heavy pruning may kill the plant.

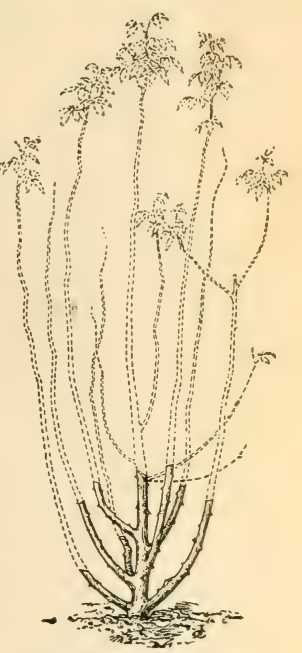

Showing where to prune

Austrian Briar roses (also the Bourbons) need very little pruning. The Wichuraianas and many of the Multifloras bloom on the branches produced the previous summer; hence these should be pruned very little during autumn or spring; but when they have frnished blooming entirely remove the old flowering shoots to give the new growth plenty of light and air.

Climbing and Pillar roses need be cut back but onethird to one-fifth, and on old, well-established plants, the old, enfeebled wood should also be taken out.

The base of the branches may be prevented from becoming bare. In straight branches, the sap goes to the top, leaving 
little for the buds at the base. Train the branches up crooked by putting sharp bends in the stems within 2 feet of the ground, and foliage will be produced the whole length of the stem. To get a second crop of flowers in autumn, cut 8 to io inches of wood with the flowers. Several Hybrid Perpetuals will also bloom in autumn with this treatment. (See below, and

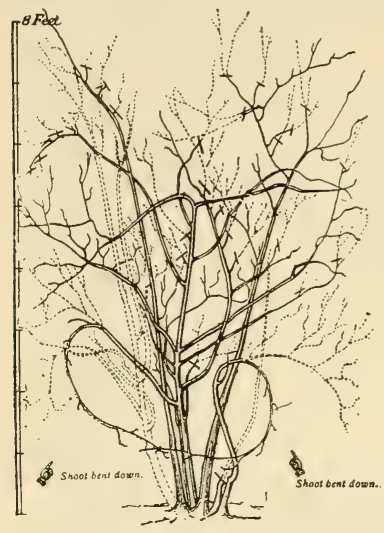

The way to prune and thin out climbing roses also the list of 162 roses on pages 43 to 62 .)

In autumn extra-Iong canes will need to be cut back a little, and perhaps tied to a stake or support, to prevent swaying and the consequent damage to the roots.

\section{How to Use This Pruning Information}

Refer to pages 43 to 62 for varieties on which information is desired. Opposite each name will be found abbreviated directions for pruning. Illustrations herewith will further explain the instructions. The key to these directions is fully explained on this and the succeeding page.

I. HARD. Thin out to the base all but from three to frve shoots, and cut these back so as to leave two or three eyes on each shoot.

2. Moderately Hard. Thin out as No. I, and cut each shoot back to about five to ten eyes.

3. Medium. Thin out as No. I; leave four to seven shoots; shorten these shoots to about half their length.

4. Sparingly. Thin out as No. I; leave four to seven shoots, which should be merely tipped.

5. Thin. No pruning required; thin out annually.

6. NoNE. No pruning required; thin out every two or three years, just to keep the plant within bounds.

7. Climbing, Pillar, and all other roses that are marked 7 can be improved by thinning, when one or more of the 
stems show plainly that they are old and past doing good service. This should not be necessary oftener than every three years. Kinds marked + are more likely to need it than kinds marked - . The needs of such roses as Mrs. Peary, Marechal Niel, etc., are not covered by any of the notes, where the climate is warm enough not to kill back the main stems. In this case, the branches should be trimmed so as to leave from two to ten eyes.

Ex. Method to use to produce exhibition specimens or Iarge flowers.

Q. Method to use to produce showy bushes or a quantity of flowers.

"Note I.-Pruning, therefore, is the art of improving the productive power, and the appearance of the plant. It consists of two distinct operations: (I) The removal of dead, weak, overcrowded, or otherwise useless shoots. Unripe wood which in the spring will usually be found to have discolored pith, caused by the winter frosts, should be cut clean away at the base of the shoot. (2) Pruning proper, the shortening of those shoots which are allowed to remain after the thinning-out process has been completed.

"The most frequent errors made in pruning are (I) leaving too many shoots when thinning out; (2) pruning severely the shoots of varieties which require little, if any, shortening; (3) pruning lightly the varieties which require severe pruning; (4) leaving rose plants crowded with shoots and cutting these to a uniform length all over the plant in the same way that a hedge is clipped.

"In thinning out a shoot, it should be either cut clean away to the base of the plant, or to its starting-point on the older shoot from which it springs, as the case may be. When the plant has been pruned, the shoots should be left as nearly as possible equidistant from each other, and regularly arranged around it so that it presents a well-balanced appearance on all sides."-National Rose Society's Hand-Book on Pruning.

Copies of this valuable book may be purchased on application to Editor "How to Grow Roses," West Grove, Pa. 


\section{Own-Root, and Budded or Grafted Roses}

Every rose-grower should learn the difference. In a budded or grafted rose, the top of a good flowering variety has been joined and made to grow upon the root of a "wild" rose. An own-root rose stands on its own feet, so that, if the top be winterkilled, the new growth from the root will bloom true as at first. Not so with the budded or grafted rose. If the top be killed, the "wild" root is worthless; throw it out.

As a general rule, for application over a broad area, the experience of many people in many different localities indicates a preference for own-root roses only in such varieties as will make vigorous growth.

Some types, however, especially some of the Hybrid Teas, when on their owr roots produce but poorly. In order to obtain vigorous growth and luxuriant bloom, such kinds are budded or grafted upon the stock of a strong-

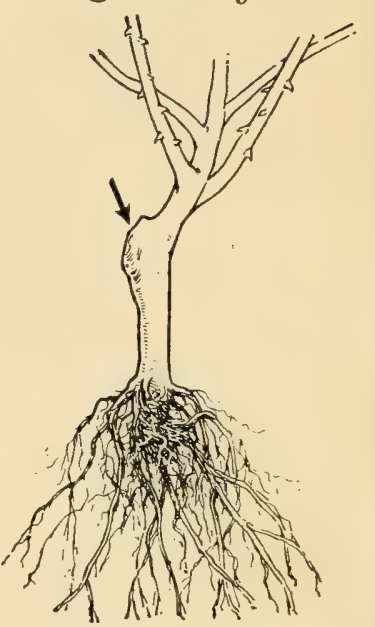

A budded rose $m$ a y be distinguished from the own-root by knotformation of the former. See arrow. growing rose. Multiffora, Canina, Manetti, and other stocks are used for this purpose. When planting own-root roses, set in the soil a trifle deeper than the stain of the soil on the stem indicates it grew before. When planting budded or grafted roses, set with the joint or union of top and root an inch below the surface of the soil, and watch for suckers. If there appears any growth originating below the union, dig away the soil and cut it off close up to the stem; otherwise it may grow up and crowd out the flower-bearing part of the plant.

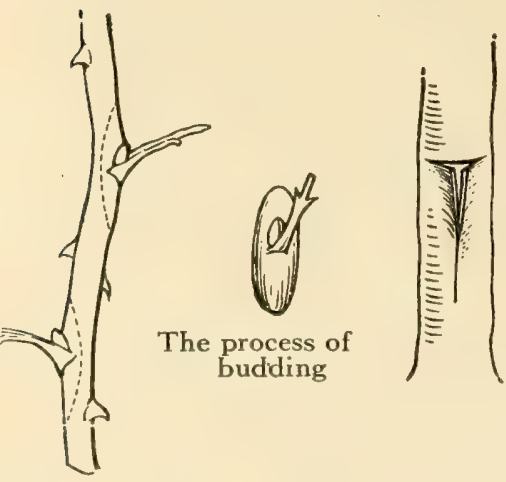

Suckers show 7 or 9 leaflets.

The majority of roses grown and planted North are budded; South the reverse is true. 


\section{Selecting the Roses}

This is a vital matter. The most complete and authoritative list of roses in our possession shows I 0,28I varieties. The most complete collection in any one plantation that has come under our observation we did not attempt to count. It is said to contain about six thousand varieties, including every known species and every variety now obtainable in the civilized worId. (This garden, the Roseraie de L'Hay, will be found more fully described on page 98.)

The average number of roses actually in commerce in the

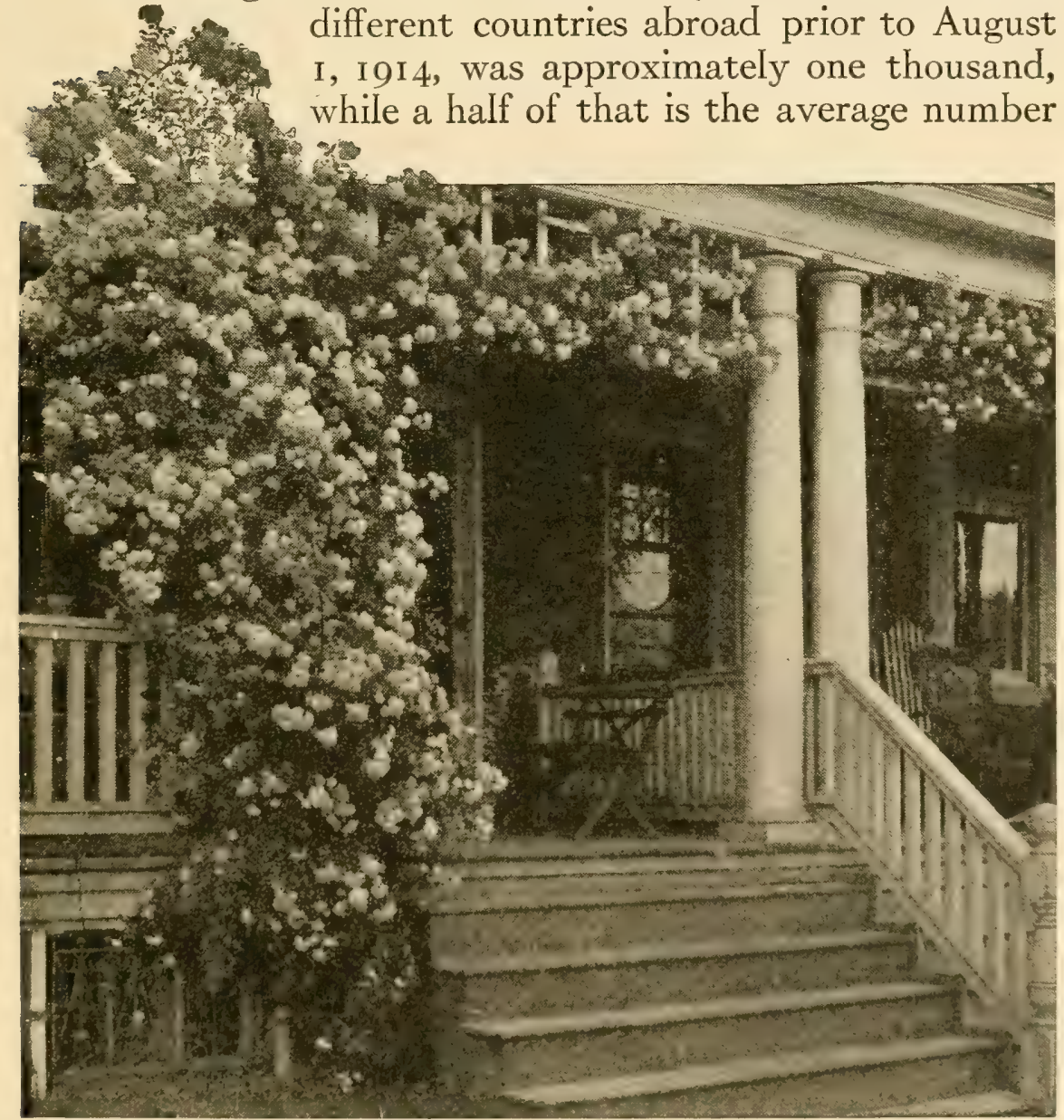

The luxuriant clusters of the white-flowered Dorothy Perkins. A good example of the Wichuraiana family 
offered in America by the leading rose firms whose products can be relied upon as true to name.

When we recall that the average amateur must confine his selection to a much smaller number even than this, often a choice two dozen kinds, the paramount importance of a proper selection is quite apparent.

Dr. Liberty H. Bailey, formerly of Cornell University, and editor of that standard authority, "Cyclopedia of American Horticulture," says: "The success of the rose in this country is very largely a question of the selection of adaptable varieties."

Pemberton, in his excellent work on "Roses," says to beginners: "State your requirements to a friend who is an expert and leave the selection to him." This book would be a "friend" to every rose-grower,-how "expert" you must judge from its contents.

America is a big country, and allowances must be made for differences in soil, climate, and other conditions. Rules are offered for use and application by the reader to the conditions that obtain in his or her locality. If there arise conditions not herein covered, the author will be glad from his own experience to assist readers in solving their individual problems.

Where do you live? The answer to this question is the first key to the selection of the right roses. Some varieties will withstand severely cold winters from which other varieties would die. Do you want dwarf, bedding, pillar, or vigorous climbing roses? Would you prefer a great show for a month or more in the early summer, or a more or less continuous bloom throughout the autumn also? These various important characteristics will be mentioned in the descriptions of 162 roses on pages 43 to 62 . The following explanations will enable you more fully to understand the terms used. We state after the name of each rose: (I) the class to which it belongs; (2) the color of the flower; (3) the character of the leaves, when it is particularly worthy of mention; (4) the character of growth (vigorous, moderate, etc.); (5) the purposes for which best suited; (6) the way to prune 


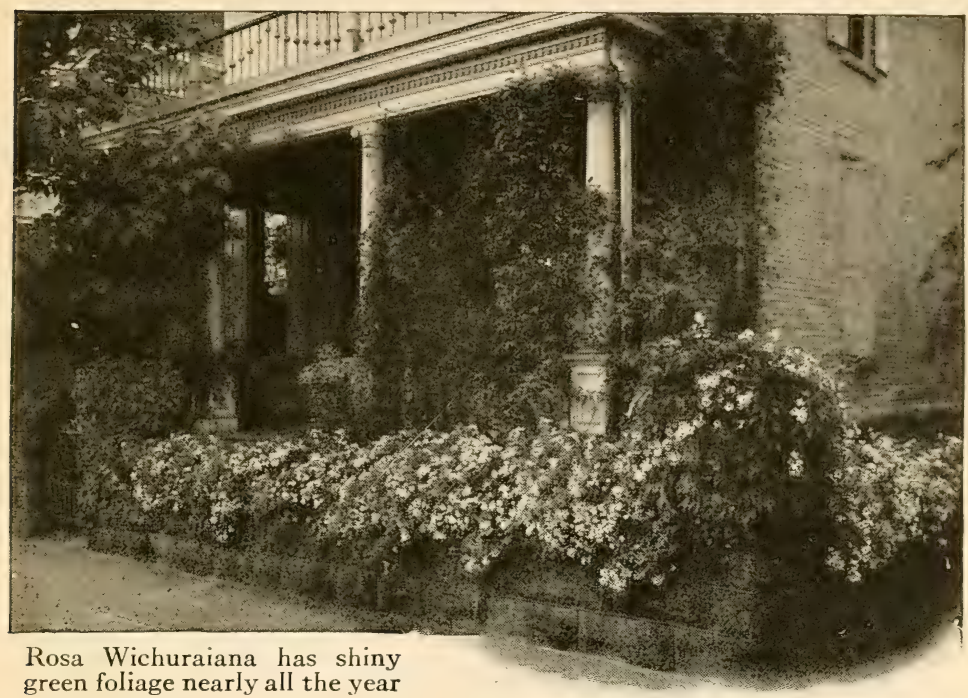

the variety; (7) other noteworthy remarks. We have endeavored to avoid all exaggeration.

After the name of the variety, the class to which it belongs is indicated by the following abbreviations:

\section{SeCTION I}

T.-Tea

Bou.-Bourbon

C.-China

H.T.-Hybrid Tea

P.-Polyantha

T.P.-Tea Polyantha

\section{Section II}

N.-Noisettes

C.T.-Climbing Tea

C.H.T.-Climbing Hybrid Tea

C.P.-Climbing Polyantha

C.T.P.-Climbing Tea Polyantha
Section III

A.B.-Austrian Briar. Per.Pernetiana, or Hybrid Austrian Briar

D.-Damask

H.P.-Hybrid Perpetual

M.-Moss

Pr.-Provence

R.-Rugosa and Hybrid Rugosa

\section{Section IV}

Mult.-Multiflora

Bank.-Banksian

Cl. M.-Climbing Mloss

S.B.-Sweetbriars

W.-Wichuraiana and hybrids

In addition to 162 leading roses listed on pages 43 to 62 inclusive, see also (pages I Io to I I5) a list of the important roses in each class named above. 


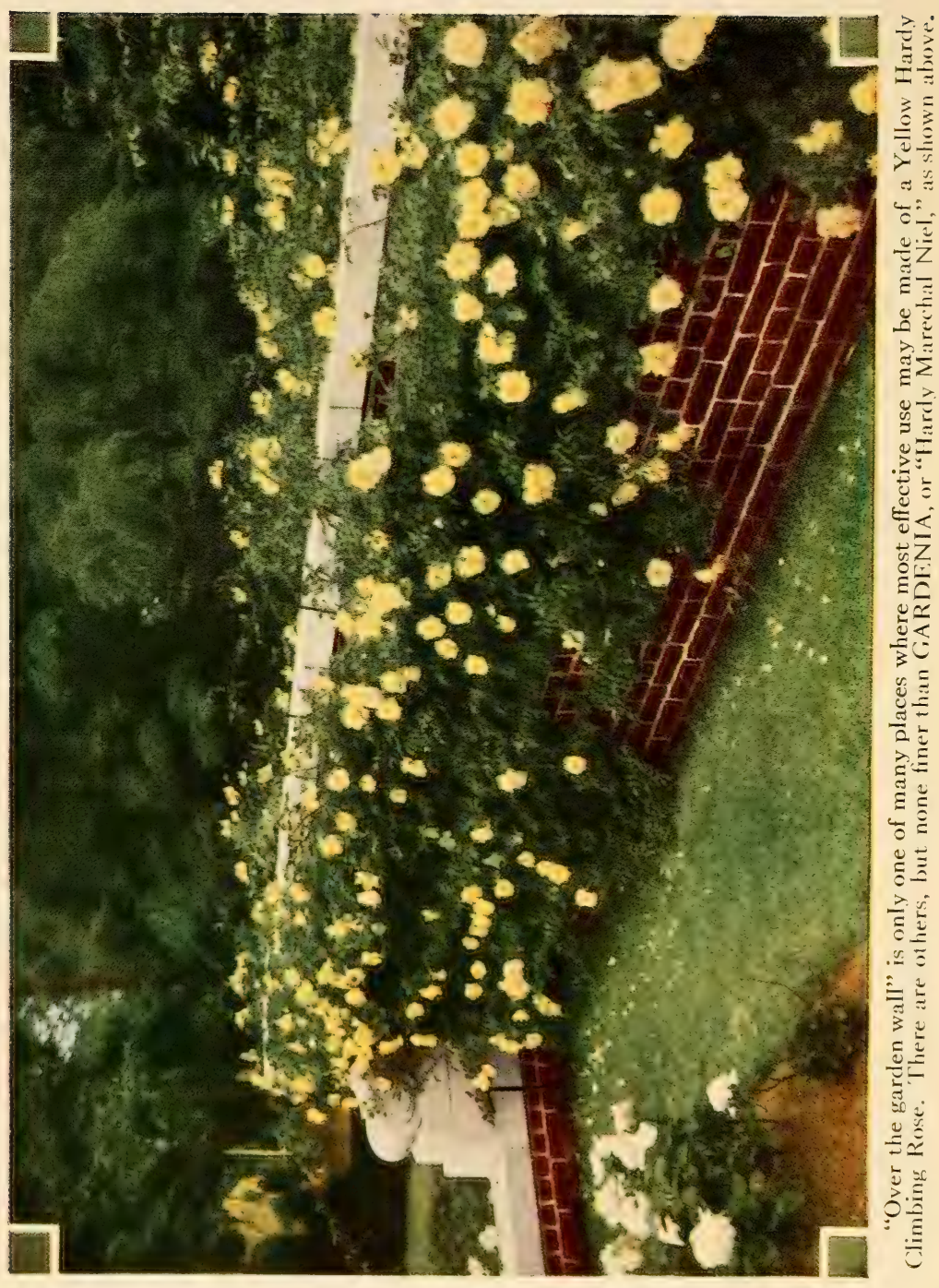


It will be helpful to remember, when referring to the above four sections, that sections III and IV contain the hardiest roses. Roses in these classes will live out over winter in the latitude of Philadelphia without protection, although all roses in this and colder regions will be the better for protection. The classes in sections I and II require carefuI protection in a climate like this, especially the first ones named in each section, which are better suited for growing south of Washington, D. C., and in correspondingly mild climates.

As to bloom, sections I and II will bloom more or less throughout the growing season. Sections III and IV are mostly known as summer bloomers, and are in their greatest glory for only a few weeks in early summer. Some of the Hybrid Perpetuals and Hybrid Austrian Briars will also make an autumn showing.

The character of growth is indicated upon a scale arranged as follows: Weak, moderate, moderately vigorous, vigorous, very vigorous; "robust" indicates sturdy and bushy, but short growth. Climbers are described either as vigorous climbers, suitable for low pillar or trellis, or very vigorous, suitable for archways, pergolas, or high trellis.

\section{Terms Used to Describe Appropriate Uses}

(Also key to descriptions on pages 43 to 62)

GARDEN.-Recommended for general lawn or garden cultivation.

BeDDING, i. e., free-flowering and of rather compact growth-good for massing in beds, either several of a kind or with other bedding roses.

Pillar.-Excellent for training up to a low pillar, stake, or post.

ARCH.-For covering an archway.

PERgola.-For growing over a pergola.

WALL.-Suitable for training up the face of a wall or side of a building.

Creeping.-Good for covering a bank, stumps, rocks, etc. 
Trellis.-Grows well on a trellis or support.

Bush.-Makes a good bush when planted alone and allowed to develop.

Рот, or CuT-FLowers. - Those that have particularly Iong stems and other qualities that make them peculiarly fitted for cutting. Good also under glass.

Boutonniere.-Well-formed buds and not so large but that it is appropriate for a buttonhole or corsage bouquet.

EDGING.-Makes an excellent edging to a rose-bed or border, bed, or pathway.

HEDGE.-Adapted for making a hedge, either all one kind or with others.

TREE or STANDARD.-Kinds that do well in tree form, as illustrated on page 98 .

Note also at the close of this chapter a section devoted to the best roses for each particular purpose in your garden. We feel that entire dependence may be placed upon these recommendations beginning page 64 , based upon the information gained after many years' correspondence with patrons in all parts of the United States.

In a broader way the reader will surely find great interest in cultivating a more intimate acquaintance with this great rose family. Opportunity for further study of this subject is offered in the Analysis of Species and outline of different classes beginning on pages 108 and I 10.

Following these sets for special purposes, and beginning on page 77 , will be found recommendations of the varieties that eminent amateurs, or professionals, have found best adapted to each of eight different typical sections of our country.

But comparatively few people can actually plant more than a small proportion of any such extended list, and therefore we list on the. pages immediately following a shorter list of the leading varieties from any of which it will be entirely safe to select. The reader may still have some failures, but they will serve as stepping stones of knowledge surely learned on which to build greater success. 


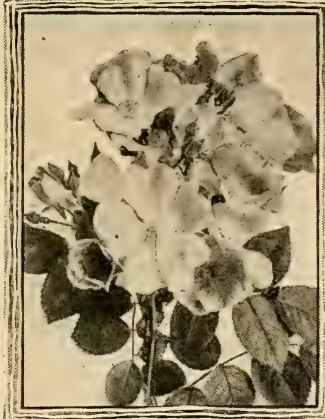

American Pillar See page 44

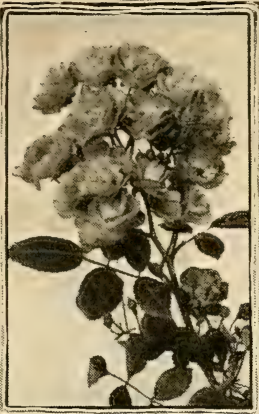

A Baby Rambler See page 44

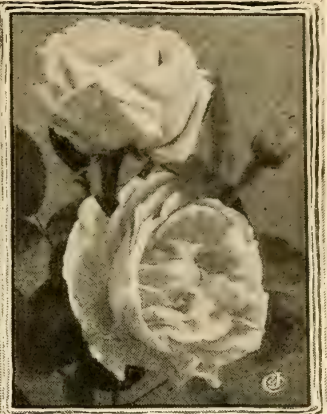

Anna de Diesbach See page 44

\section{One Hundred and Sixty-two Choice Roses}

Loving roses as we do; living among them and watching them closely and constantly, under all sorts of conditions; having before us reports upon roses from every country on earth to which our roses go, and knowing, too, the prizewinners and kinds that have pleased amateurs here and almost everywhere; watching the new roses as they "come out," testing all kinds and holding fast to those which are good,- - out of an experience like that has come our choice of these 162 roses. See abbreviations for class, growth, purpose, and pruning, explained on pages 39 to 42 .

AGNES EMILY CARMAN. H.R. Flowers brilliant crimson, velvety; very fragrant. Hedge, bush. Perfectly hardy. Prune 5, $7+$.

ALBERIC BARBIER. H.W. Flowers in clusters, double, creamy white with canary-yellow center; fragrant. Leaves bronzy red in spring and glossy; almost evergreen, and not liable to be troubled with insects. Very vigorous. Pergola, arch, banks, etc. Prune 6, 7-.

ALEXANDER HILL GRAY. T. Flowers deep lemon-yellow, which intensifies as the blooms develop; large, of deep substance and perfect formation. Gold Medal, N. R. S. Garden, bedding, cutflower. Prune 4.

ALISTER STELLA GRAY (Golden Rambler). N. Flowers rich apricot-yellow, changing to white with yellow center; delightfully fragrant and constant in bloom. Moderately vigorous. Pillar, arch, trellis. Needs winter-protection. Prune 5, 7 +. 
AMERICAN BEAUTY. H.P. Flowers deep pink to crimson; intensely fragrant. Cut-flowers. Prune 2 for Ex., 4 for Q.

AMERICAN BEAUTY, CLIMBING. H.W. Flowers deep pink to crimson; fragrant. Produces hundreds of perfect blooms at one time. Very vigorous. Pergola, arch, porch, etc. Prune 6, 7-.

AMERICAN PILLAR. MuIt. Flowers chaste pink; single; large, 3 to 4 inches across; in large clusters. Leaves almost evergreen. Very vigorous. Has attractive, brilliant red hips in autumn. Pergolas, pillar, etc. Prune 6, 7. (See illustration in color, on title-page.)

ANNA DE DIESBACH. H.P. Flowers rose; fragrant; profuse. Garden. Prune I for Ex., 3 for Q. (See illustration, page 43.)

ANTOINE RIVOIRE. H.T. Creamy white to deeper yellow and peachy pink center. Vigorous. Garden and bedding. Prune 3.

ARTHUR R. GOODWIN. H.T. Buds and flowers rich coppery orange-red which shades to salmon-pink as the flower ages; very Iasting; blooms large and double. Garden, bedding. Prune 3.

AUNT HARRIET. H.W. Flowers scarlet-crimson, very bright. Vigorous. Pergola, pillar. Prune 6, 7.

AVIATEUR BLERIOT. H.W. Flowers deep saffron-yellow and copper. Vigorous. Pergola, arch, pillar, etc. Prune 6, 7.

BABY DOROTHY. P. Flowers bright pink. Incessant bloomer. Dwarf, 20 in. Bedding, edging. Prune 3.

BABY RAMBLER, RED (Mme. Norbert Levavasseur). P. Flowers dark red. Blooms all the time. Dwarf. Bedding, edging. Prune 3. (See cut page 43.)

BEAUTY OF ROSEMAWR. Bou. Flowers rich carmine-rose, veined with creamy white. Very floriferous. Garden, bedding. Prune 4.

BESS LOVETT. H.W. Flowers scarlet-crimson. Very vigorous. Pergola, pillar, arch, etc. Prune 6, 7.

BETTY. H.T. Flowers coppery rose and golden yellow; very fragrant. A novelty. Garden, bedding. Prune I for Ex., 3 for Q.

BIRDIE BLYE. Mult. Flowers bright satiny rose. Continual bloomer. Grows 4 to 6 feet. Pillar, bush. Prune 5.

BLANC DOUBLE DE COUBERT. H.R. Flowers white, double, large and showy. Very hardy. Vigorous. Hedge, bush. Prune 5, 7-.

BLANCHE MOREAU. M. Flowers pure white; large and full. Bedding. Prune 3.

BRIDESMAID. T. Flowers rose-pink, crimson-shaded; fuIl and fragrant. Bedding, cut-flower. Prune 2 for Ex., 4 for Q. (See illustration in color, page ro3.)

CARMINE PILLAR. C.H.T. Flowers single, rich carmine-red; very fine; looks like a clematis. Vigorous. Trellis, pillar, arch. Prune 5. 


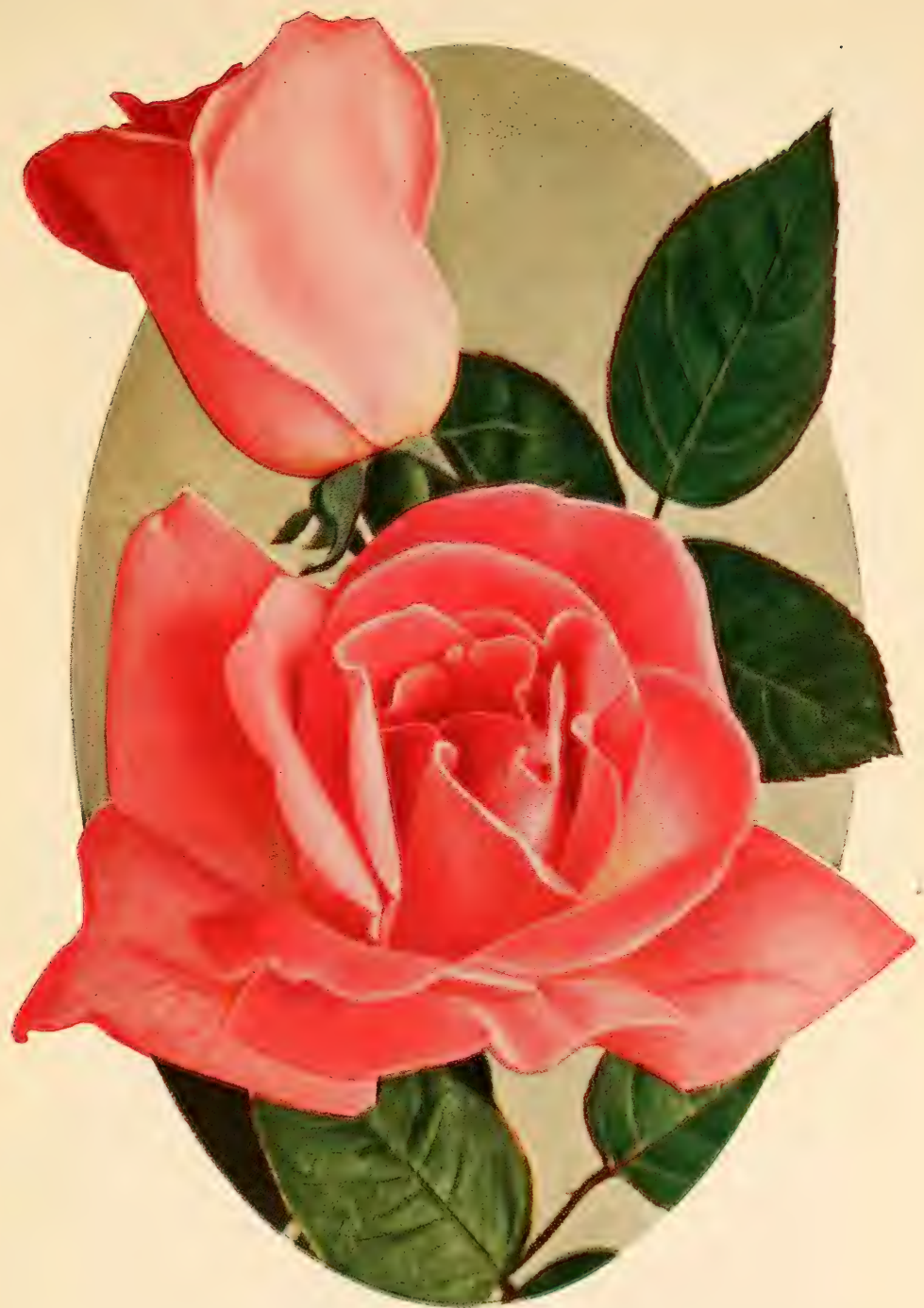

With petaIs fashioned like sea-shells, tinted and toned in shades of rose and pink, superlatives fail in describing the satisfactory beauty of KILLARNEY, the renowned Hybrid Tea Rose.

Fortunate it is for Rose-lovers that Mother Nature has been so generous in giving us so many members in the Killarney family, all of them rare beauties, such as Killarney Brilliant, Killarney Queen, and White Killarney.

For open-ground planting under different conditions of climate, this Killarney Rose family may be depended upon to repay bountifully the attention and care which all Roses should receive. 
CHAMPION OF THE WORLD (Mrs. De Graw). Bou. Flowers rich, rosy pink; large, full and deliciously sweet. Free bloomer. Garden bedding. Prune 5 .

CHATEAU DE CLOS VOUGEOT. H.T. Flowers velvety maroon, shaded frery red, very dark. Garden. Prune 2. (See illustration, page 47.)

CHRISTINE WRIGHT. H.W. Flowers clear wild-rose-pink; beautiful in bud. Foliage large, thick, leathery. Pillar, arch, arbor, trellis. Prune 6, 7.

CLIO. H.P. Flowers flesh-color, shaded pink; Iarge; fine form. Vigorous. A very choice variety. Garden. Prune I for Ex., 3 for Q.

COLUMBIA. H.T. Flowers rose-pink, very large and double. Garden, bedding. Prune I for Ex., 3 for Q.

CONRAD F. MEYER. H.R. Flowers clear silvery rose; Iarge, perfectly double, elegantly formed; very fragrant; flowers and buds of fine form. Very hardy. Garden, bush or hedge. Prune $6+$.

CORONATION. H.W. Flowers crimson-scarlet. Very vigorous. New. Pergola, arch, porch, etc. Prune 6, 7-.

CRESTED MOSS. M. Flowers choice pink, and heavily mossed. A lovely old favorite. Bedding. Prune 3.

DEVONIENSIS. T. Flowers creamy white with rosy center. Very full. An old-time favorite. Garden, bedding. Prune 2.

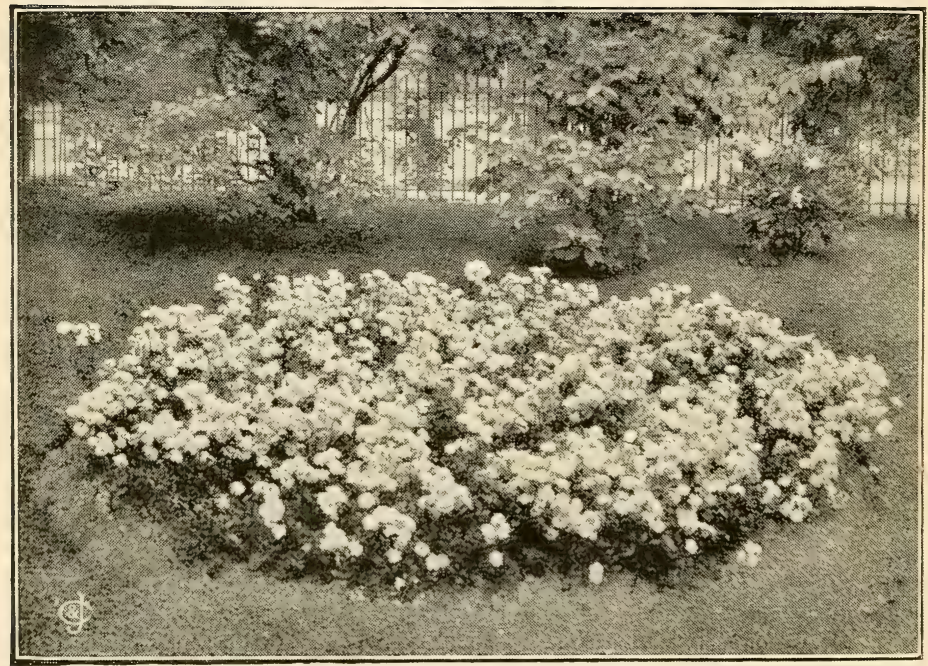

An all-summer show of bloom. An example of what Baby Ramblers will do in a bed 


\section{ROSES FOR AMERICAN GARDENS}

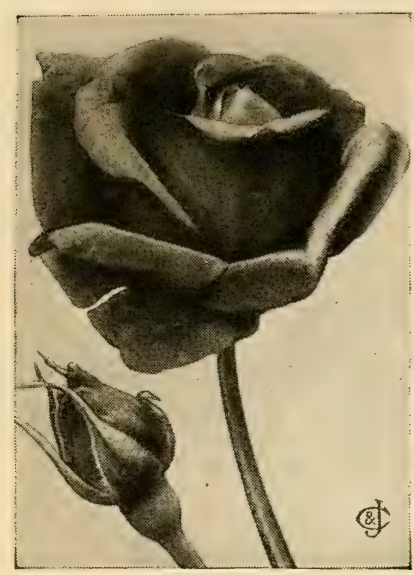

Chateau de Clos Vougeot (see p. 46)

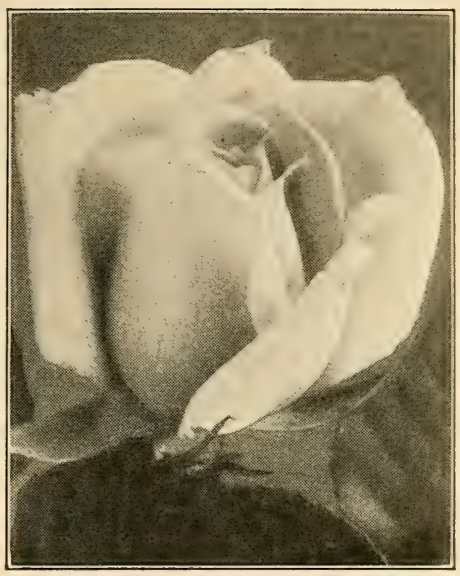

Sunburst (see page 6I)

DR. W. VAN FLEET. H.W. Flowers rich flesh-color. Stems i 8 inches long. CHOICE. Very vigorous. Pergola, arch, etc. Prune 6, 7-.

DOROTHY PERKINS. H.W. Flowers beautiful shell-pink; freebloomer; large clusters. Most popular rose in its class and color, and blooms in time for use at June weddings. Very vigorous. Arches, porches, pergolas, etc. Prune 6, 7-. (See illustration in color, page 58.)

DOROTHY PERKINS, WHITE. H.W. Flowers snow-white; freebloomer; large clusters. Very vigorous. Habit like Pink Dorothy Perkins. Arches, porches, pergolas, etc. Prune 6, 7-.

DUCHESSE DE BRABANT. T. Flowers deep rosy pink, edged with silver. Has been extensively planted about the White House, at Washington, D. C., a free bloomer. Bedding. Prune 4.

DUCHESS OF WELLINGTON. H.T. Flowers intense saffronyellow. Garden, bedding, cut-flower. Prune 3. (See cut page 49.)

ELLEN POULSEN. T.P. Flowers brilliant pink; full; sweet-scented. Very floriferous. Garden, bedding, edging. Prune 3.

ERNA TESCHENDORFF. P. Flowers rich crimson, freely produced. An improved Red Baby Rambler. Bedding, edging. Prune 3.

ETOILE DE FRANCE. H.T. Flowers intense, brilliant crimson; extra-large, double; very free bloomer; fragrant; buds large, pointed. Vigorous. Bedding. A choice variety. Prune 2.

EXCELSA (Red Dorothy Perkins). H.W. Iridescent rosy crimson. Very vigorous. Late-flowering. Fine in every way. Arch, porch, trellis, etc. Prune 6, 7-. 


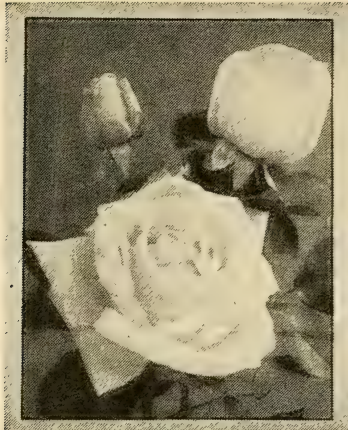

Frau Karl Druschki

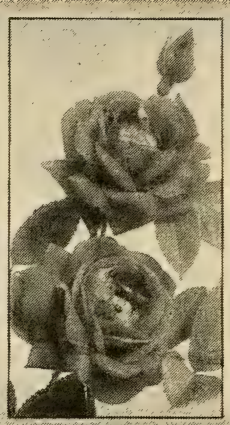

Gen. Jacqueminot

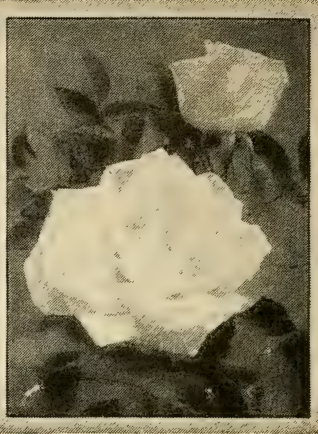

Gloire Lyonnaise

See page 49

FLORENCE PEMBERTON. H.T. Flowers creamy white, suffused pink; large, full, perfect form; high-pointed center. Bush, garden. Prune 2.

FRANCIS SCOTT KEY. H.T. Flowers crimson-red and very full. Garden, bedding. Prune 2.

FRAU KARL DRUSCHKI (White American Beauty). H.P. Flowers pure snow-white; immense ( 4 to 5 inches across), perfectly double. The finest pure white rose in this class; not fragrant. Vigorous. Bedding, bush, garden. Prune I for Ex., 3 for Q. (See illustration.)

GARDENIA. H.W. Flowers yellow, changing to creamy white; fragrant; free bloomer. Very vigorous; creeping. Prune 6, 7-. (See illustration in color, page $\mathbf{1 2 .}$.)

GENERAL JACQUEMINOT. H.P. Flowers brilliant crimson, velvety; fragrant. Vigorous. Bedding, garden, pot, and standard. Prune 2 for Ex., 3 for Q. (See illustration in color, page 70.)

GENERAL MACARTHUR. H.T. Flowers glowing crimson-scarlet; fragrant. Vigorous. Bedding, garden. Prune 2.

GENERAL-SUPERIOR ARNOLD JANSSEN. H.T. Flowers deep glowing carmine, large, and freely produced. Garden, bedding. Prune 2.

GEORGE ARENDS (Pink Frau KarI Druschki). H.P. Flowers tender, rose-pink. Garden, bedding. Prune I for Ex., 3 for Q.

GEORGE DICKSON. H.T. Flowers velvety dark crimson, back of petals heavily veined with deep, pure crimson-maroon. Garden, bedding. Prune 2.

GEORGE ELGER. P. Flowers rich chrome-yellow; small but produced continually. Garden, bedding. Prune 3.

GLOIRE DE CHEDANE GUINOISSEAU. H.P. Flowers bright vermilion-red. Bedding, garden. Prune 2 for Ex., 3 for Q. 


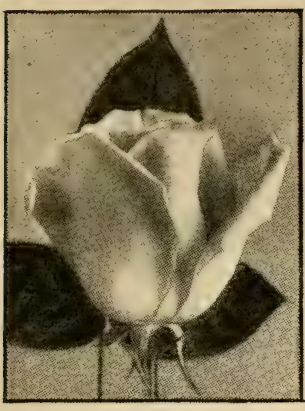

Duchess of Wellington See page 47

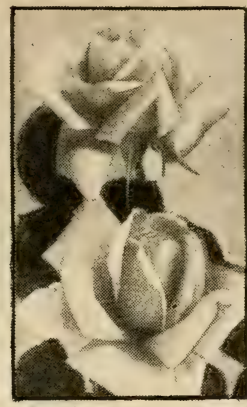

Los Angeles See page 52

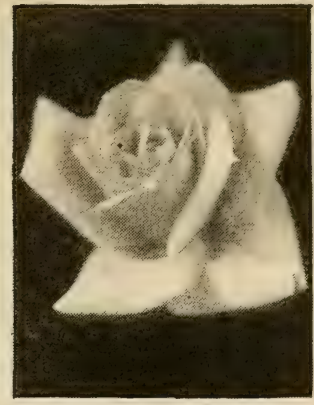

Ophelia See page 59

GLOIRE LYONNAISE. H.P. Flowers pale lemon; large. Very vigorous. Garden, bedding. Prune 2 for Ex., 3 for Q. (See illustration, page 48.)

GRUSS AN AACHEN. T.P. Flowers flesh-pink and yellow; very double and free-flowering. Vigorous. Edging, bedding. Prune 4.

GRUSS AN TEPLITZ. H.T. Flowers bright crimson; free bloomer. Vigorous. Garden, bedding, bush, and standard. Prune 5.

GRUSS AN TEPLITZ, CLIMBING. C.H.T. Flowers crimson, passing to velvety, fiery red. Vigorous. Pillar, arch. Prune 7-.

HADLEY. H.T. Flowers deep velvety crimson that does not fade; perfectly formed. Garden, bedding. Prune I for Ex., 3 for Q.

HARISON'S YELLOW. A.B. Flowers clear golden yellow cover the bush; blooms early. Vigorous. Bush, hedge. Prune 5.

HARRY KIRK. T. Flowers deep sulphur-yellow with edge of petals lighter; intensely fragrant. Garden, bedding. Prune 2.

HENRI MARTIN. M. Flowers bright rosy red; fragrant; Iarge. Free bloomer; vigorous. Fine in its class. Prune 3.

HERMOSA. C. Flowers pink, in clusters; fragrant. Free bloomer; vigorous. Garden, bedding, and standard. Prune 3.

HIAWATHA. H.W. Flowers brilliant scarlet; single; bright and effective. Vigorous. Arch, trellis, etc. Prune 6, 7-:

HOOSIER BEAUTY. H.T. Flowers glowing crimson; one of the richest-colored roses in cultivation; large, full, and deliciously sweet. Garden, bedding, cut-flower. Prune 3.

HUGH DICKSON. H.P. New. Flowers brilliant crimson, shaded scarlet; very large and full; fine form. Free-flowering and vigorous. Highly perfumed. Garden. Prune I for Ex., 3 for Q. 
HUGONIS. Species. New. Flowers clear yellow, single, but produced in such profusion that they almost hide the foliage. Foliage is small and dainty, more like an acacia than a rose leaf. Hardy everywhere in the United States. Bush, hedge. Prune 5.

HUGO ROLLER. T. Flowers lemon-yellow and crimson. A teascented "pictorial" flower. Garden, bedding. Prune 2 for Ex., 4 for Q.

IRISH FIREFLAME. H.T. Flowers orange and crimson; large and single, borne in lovely sprays. Garden, bedding. Prune 3.

J. B. CLARK. H.P. Flowers intense, deep scarlet, shaded blackish crimson. Vigorous. Garden, bedding. Prune 2 for Ex., 3 for Q.

JONKHEER J. L. MOCK. H.T. Flowers carmine on the outside, lovely soft pink inside. Garden, bedding, cut-flower. Prune 2.

JOSEPH HILL. H.T. Flowers pure salmon and gold, outside of petals pinkish copper. Garden, bedding. Prune 2.

JULIET. Per. Flowers old-gold on the outside while the inside is rosy red, changing to deep rose as the flowers expand. Large, full, and delightfully fragrant. Garden, bedding. Prune 4.

KAISERIN AUGUSTE VICTORIA. H.T. Flowers white, shading to Iemon; deep; full; fragrant. Free bloomer. Garden. Prune 3. (See page 6o.)

KATHARINA ZEIMET (White Baby Rambler). P. Flowers pure white, blooms incessantly. Bedding, edging. Prune 3. (See illustration, page 46.)

KILLARNEY. H.T. Flowers brilliant pink; Iong, pointed buds. Free bloomer; moderately vigorous. A great favorite. Garden, bedding, cut-flower. Prune 3. (See illustration in color, page 45.)

KILLARNEY BRILLIANT. H.T. Flowers Iarger, more double, and a deeper pink than the parent Killarney; fragrant. A free bloomer. Garden, bedding, cut-flower. Prune 3.

KILLARNEY, WHITE. H.T. Flowers pure white, long-pointed buds. Vigorous. Garden, bedding, cut-flower. Prune 3. (See illustration, page I53.)

LADY ALICE STANLEY. H.T. Flowers deep coral-rose and pale flesh; large; exceptionally full; very lasting when cut. Garden, bedding, cut-flower. Prune 3.

LADY ASHTOWN. H.T. Flowers pale rose, shading to yellow at base of petals. Garden, bedding. Prune I for Ex., 3 for Q.

LADY ASHTOWN, CLIMBING. C.H.T. Flowers pale rose, shading to yellow at base of petals. Vigorous. Pillar, trellis, arch. Prune 6.

LADY HILLINGDON. T. Flowers deep apricot-yellow, shading to orange. Garden, bedding, cut-flower. Prune 2. (See cut, page 52.)

LADY MARY WARD. H.T. Flowers rich orange, shaded deeper orange with metallic veneering. Garden, bedding. Prune 2.

LADY PIRRIE. H.T. Flowers coppery red, changing to salmon and ivory-white. Garden, bedding. Prune 2. 


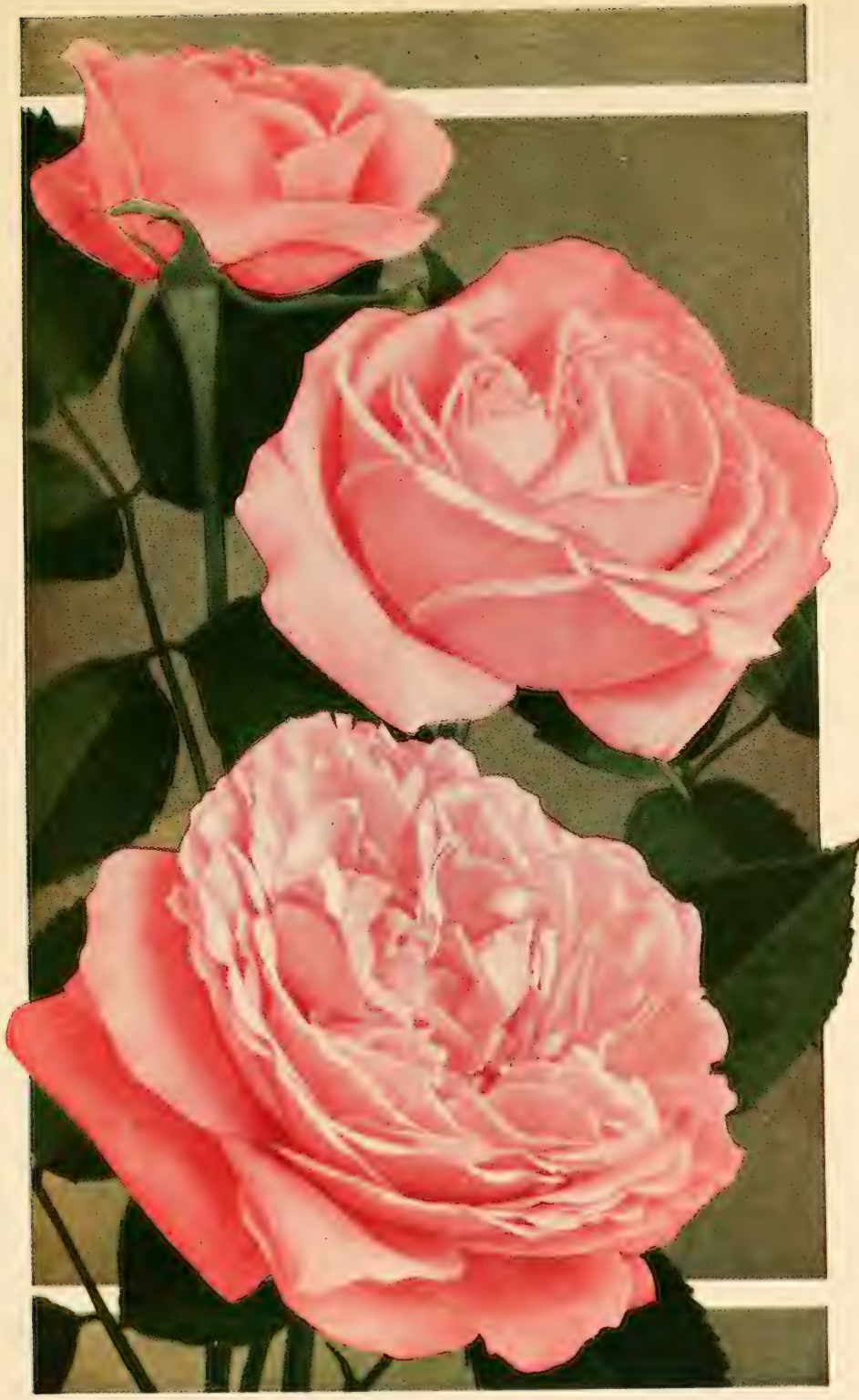

Among the pink Hybrid Perpetual Roses, MRS. JOHN LAING stands well in the lead, - not so large as Paul Neyron, but more free in bloom, with excellent form, clear color and rich fragrance. GEORGE ARENDS also is worth noting as in the same class with the above and with even finer form. 


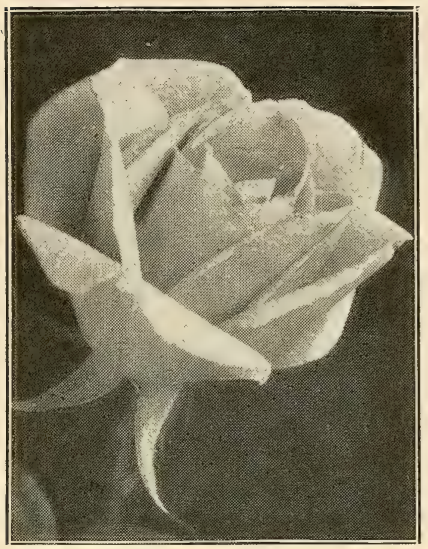

Lady Hillingdon (see page 50)

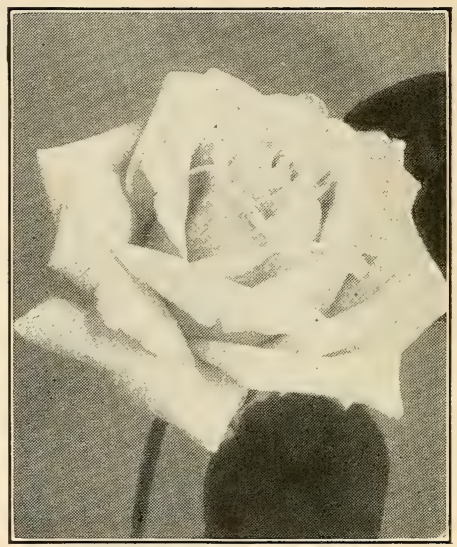

Wm. R. Smith (see page 62)

LA FRANCE. H.T. Flowers silvery rose, changing to pink; fine form; sweet; large; lovely buds. Moderately vigorous. Garden, bush, standard, and cut-flower. Prune 2. (See illustration, page 53.)

LA TOSCA. H.T. Flowers rose. Free bloomer; good; vigorous. Garden, bush, bedding. Prune 2 for Ex., 4 for Q.

I.AURENT CARLE. H.T. Flowers brilliant, velvety carmine; large and perfect; intensely fragrant. Garden, bedding. Prune 2. (See p. 57.)

LE POILU. H.W. Flowers satiny rose, passing to pinkish Iavender. Vigorous. Pergola, arch, porch, etc. Prune 6.

LOS ANGELES. H.T. Flowers Iuminous pale pink and coral shaded with gold; large and very fragrant. Vigorous. Garden bedding. Prune I for Ex., 3 for Q. (See illustration, page 49.)

LOUISE CATHERINE BRESLAU. Per. Flowers shrimp-pink, shaded with reddish coppery orange and chrome-yellow on the reverse of petals. Garden, bedding. Prune 5.

LOUISE WELTER (Baby Tausendschön). P. Flowers deep pink to white, identical in color with the popular climbing Tausendschön, or Thousand Beauties. Bedding, edging. Prune 5.

MME. ALFRED CARRIERE. N. Flowers cream-white, tinged pale yellow; large, full, double, and sweet. Vigorous grower. Porch, arch, trellis. Prune 7.

MME. CAMILLE. T. Flowers flesh, changing to salmon; large, full and sweet. Constant bloomer; vigorous. Bedding. Prune 2.

MME. CAROLINE TESTOUT. H.T. Flowers clear pink, edged silvery rose. Magnificent variety. Garden, bedding. Prune 2. (See illustration in color, page $\mathbf{1 2 .}$.) 


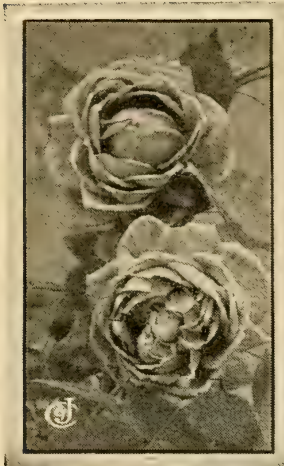

Magna Charta See page 56

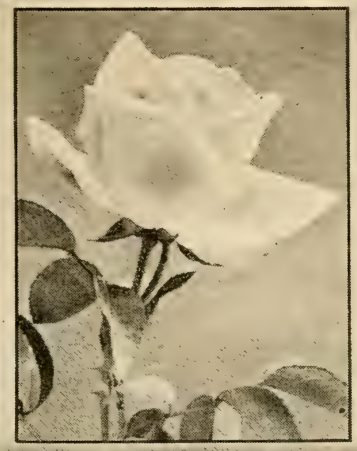

White Killarney

See page 50

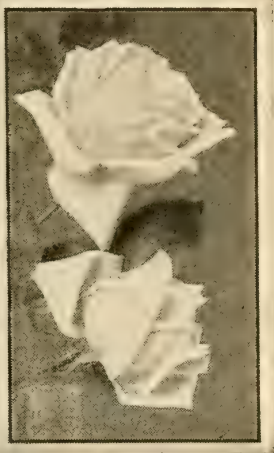

La France

See page 52

MME. CAROLINE TESTOUT, CLIMBING. C.H.T. Flowers clear, rich pink; large and full. Vigorous. Pillar, arch, trellis. Prune 7.

MME. CHARLES LUTAUD. H.T. Flowers deep chrome-yellow, sometimes tinged rosy scarlet. Garden, bedding. Prune 2.

MME. EDMOND ROSTAND. H.T. Flowers pale flesh, shaded with salmon, center reddish orange-distinct and charming. Garden, bedding. Prune 5 .

MME. EDOUARD HERRIOT (The Daily Mail Rose). Per. The most unique variety, recently introduced. Flowers medium size, semi-double, superbly colored, coral-red shaded with yellow and bright rosy scarlet, passing to prawn-red. Garden, bedding. Prune 5.

MME. EUGENE MARLITT. Bou. Flowers carmine-red; fragrant. Free bloomer. Vigorous. Bedding. Prune 4, tip severely.

MME. JULES GROLEZ. H.T. Flowers china-rose, passing to clear, rich satiny pink. Garden, bedding. Prune 2.

MME. LEON PAIN. H.T. Flowers silvery salmon, center orangeyellow. Garden, bedding. Prune 2.

MME. MELANIE SOUPERT. H.T. Flowers salmcn-yellow, suffused carmine; fragrant. Free bloomer. Garden, bedding. Prune 2. (See p.61 .)

MME. PLANTIER. Alba. Flowers pure white. Vigorous; very free bloomer. Bush, hedge. Prune 6.

MME. RAVARY. H.T. Flowers rich orange-yellow. Free-blooming and deliciously fragrant. Garden, bedding. Prune 2.

MME. SEGOND WEBER. H.T. Flowers salmon-flesh color, deep pink when opening. Garden, bedding. Prune 2.

MLLE. CECILE BRUNNER, P. Flowers seashell-pink, borne in sprays continually. Garden, bedding, bouquets. Prune 5. 


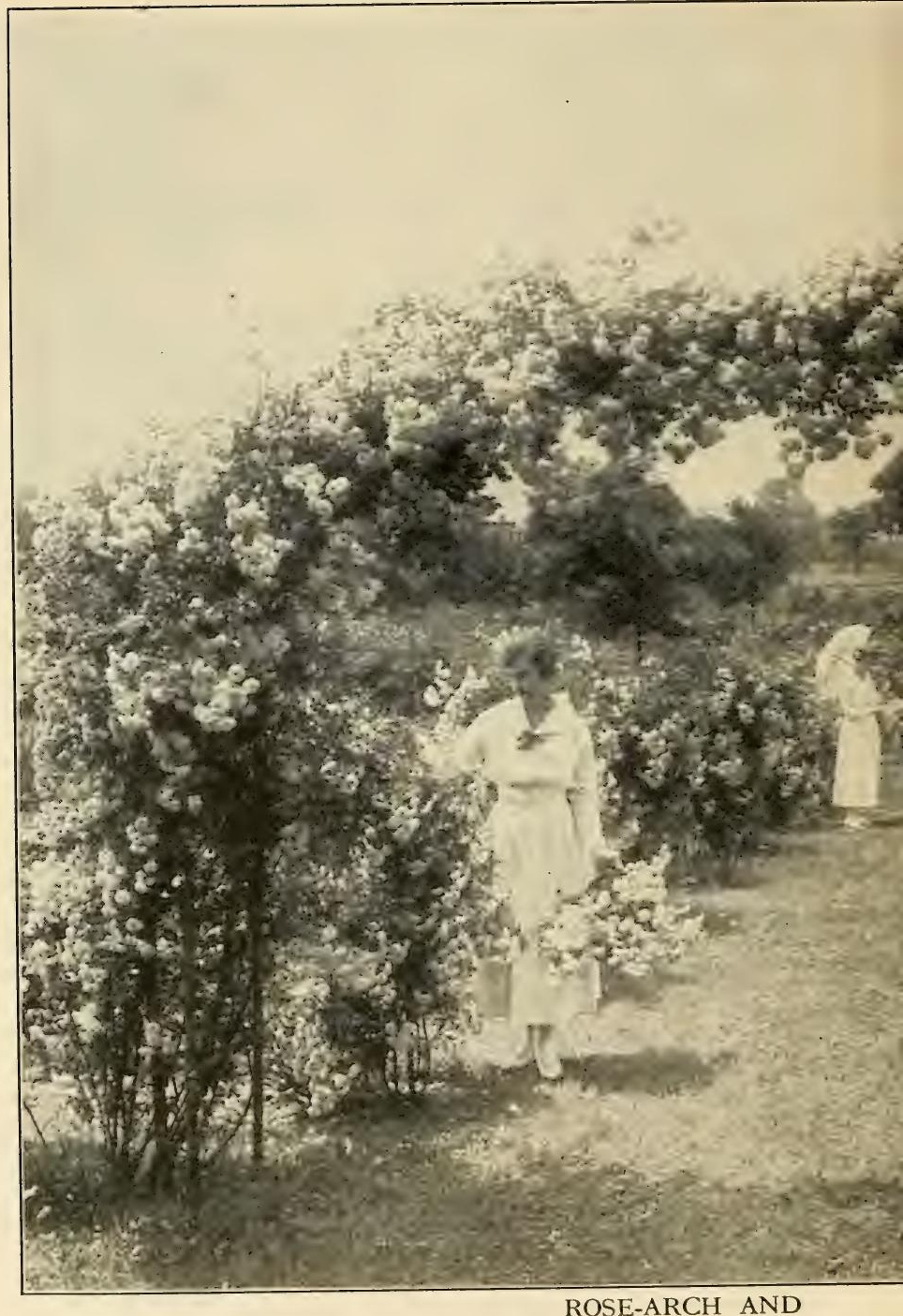




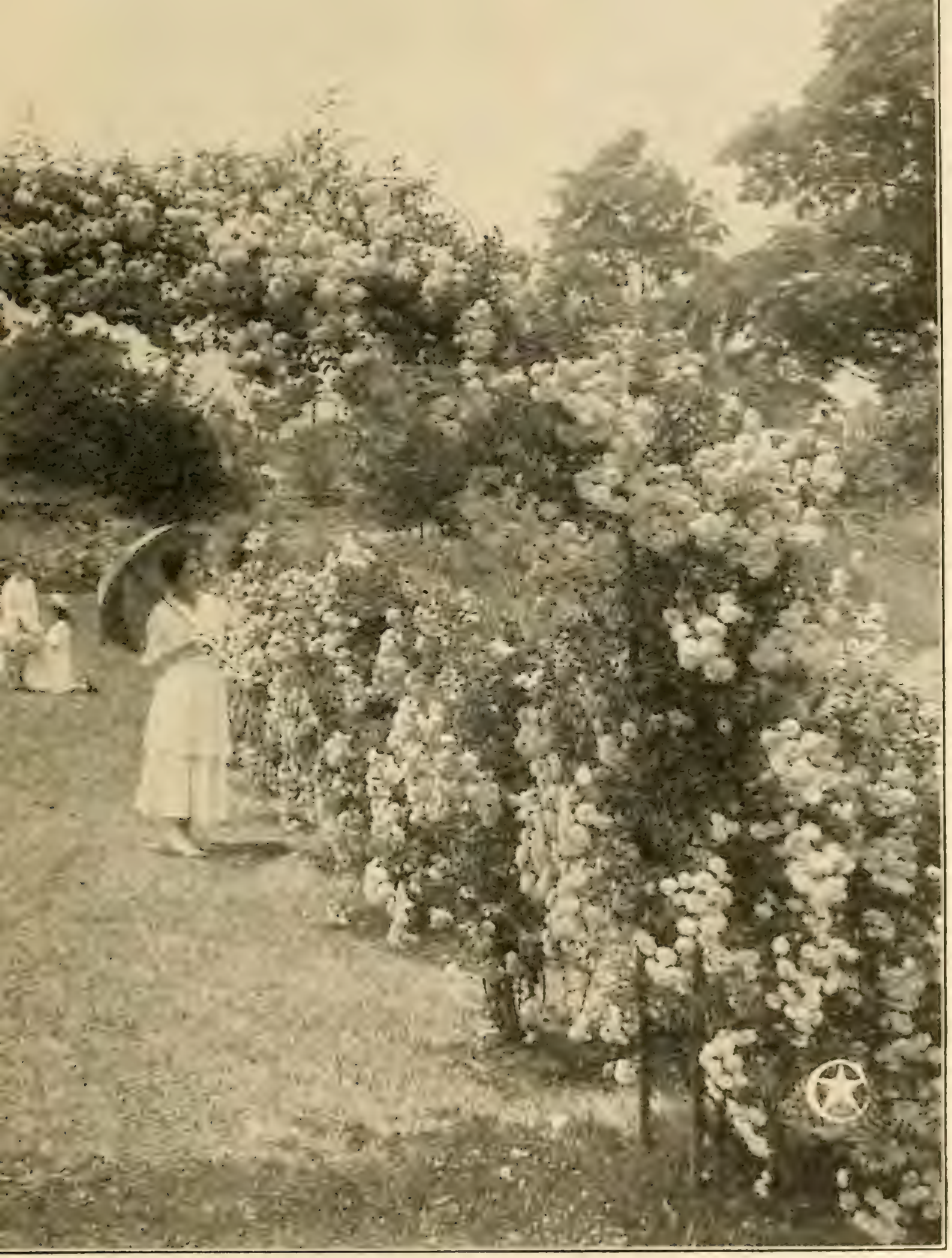

-GARDEN IN HARRISBURG 


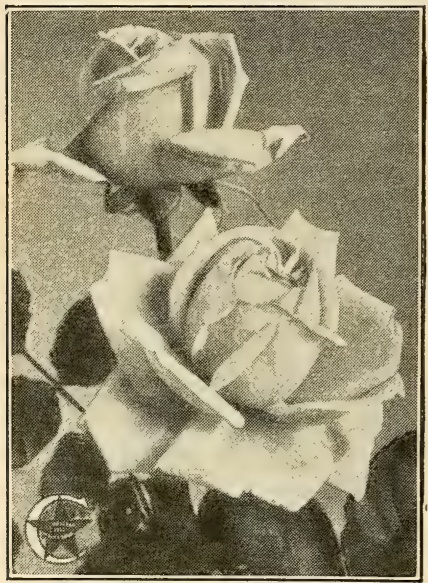

Miss Alice de Rothschild

See page 57

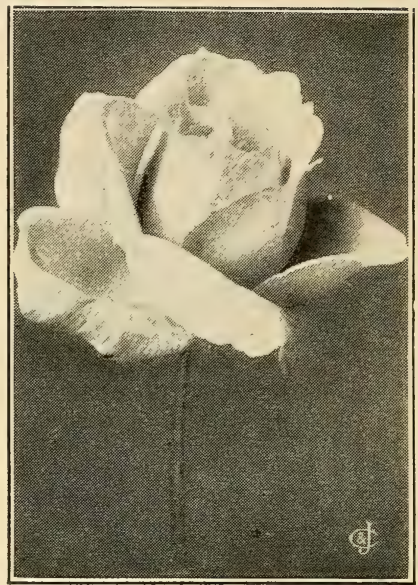

Mrs. Wakefreld Christie-Miller See page 57

MAGNA CHARTA. H.P. Flowers pink, suffused with carmine. Vigorous. Bedding. Prune 2 for Ex., 3 for Q. (See illustration, page 53.)

MAMAN COCHET. T. Flowers deep coral-pink; large, very double, full; fragrant. Vigorous. Garden, bush. Prune 2.

MAMAN COCHET, PINK, CLIMBING. C.T. Flowers coral-pink, shaded rosy crimson. Porch, pergola, arch, etc. Prune 4.

MAMAN COCHET, WHITE. T. Flowers pure white; Iarge, full and fragrant; buds long, pointed. Garden, bush. Prune 2.

MARECHAL NIEL. N. Flowers deep yellow; large, globular, fuII and sweet. Vigorous. A most beautiful climber. Hardy only in the South. Porch, pillar, pot, standard, etc. Prune 5.

MARIE PAVIE. T.P. Flowers white with delicate rose center. Unsurpassed as a bush cemetery rose. Blooms unceasingly and is quite hardy. Garden, bedding. Prune 3.

MARIE VAN HOUTTE. T. Flowers pale yellow, edged rose; Iarge, full, and fragrant. Constant bloomer; vigorous. Bedding. Prune 2.

MARQUISE DE SINETY. H.T. Buds rich yellow-ocher, suffused with carmine; the expanded flower is yellow, shaded rosy red. Garden, bedding. Prune 2.

MARY, COUNTESS OF ILCHESTER. H.T. Flowers beautiful crimson-carmine; verv large and double. Garden, bedding. Prune 2.

MARY LOVETT. W. Flowers pure pearly white; same type as the beautiful Dr. W. Van Fleet. Pergola, arch, etc. Prune 6, 7-. 


\section{ROSES FOR AMERICAN GARDENS}

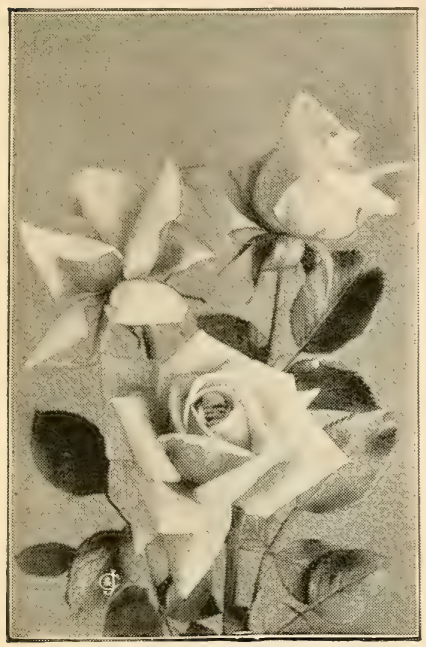

Mrs. Aaron Ward

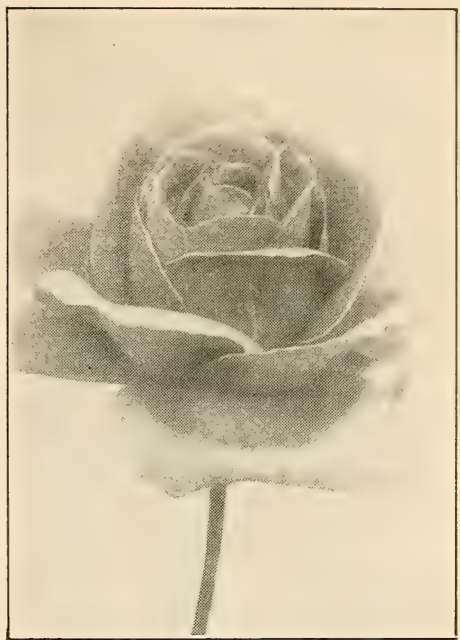

Laurent Carle (see page 52)

MAY QUEEN: W. Flowers clear bright pink and deliciously sweet. A great bloomer. Pergola, arch, pillar, bush, hedge. Prune 6.

MISS ALICE DE ROTHSCHILD. T. Flowers rich yellow. We call it bush Marechal Niel, although it is hardier. Garden, bedding. Prune 2. (See illustration, page 57.)

MRS. AARON WARD. H.T. Flowers Indian yellow, sometimes tinged salmon-rose. Garden, bedding; boutonniere. Prune 2. (See up.)

MRS. A. R. WADDELL. H.T. Flowers coppery red, suffused with salmon. Incessant bloomer. Garden, bedding. Prune 2. (See p. 6r.)

MRS. B. R. CANT. T. Flowers rose-red; large, full, perfectly double; fragrant. Constant bloomer; vigorous. Garden, bedding. Prune 3.

MRS. EMILY GRAY. H.W. Flowers yellow; does not fade. Very vigorous. Porch, arch, pergola, wall, etc. Prune 7.

MRS. JOHN LAING. H.P. Flowers soft pink; Iarge, fuII, and fragrant. Free bloomer; vigorous. Garden, bedding. Prune I for Ex., 3 for Q. (See illustration in color, page $5 \mathrm{I}$.)

MRS. ROBERT PEARY. C.H.T. Flowers Iemon-white, perfectly formed. Moderately vigorous. Pillar, trellis. Prune 5.

MRS. WAKEFIELD CHRISTIE-MILLER. H.T. Flowers soft pearly blush. Garden, bedding. Prune 2. (See illustration, page 56.)

MY MARYLAND. H.T. Flowers Iovely salmon-pink, very freely produced on Iong stems. Garden, bedding, cutting. Prune 2. 


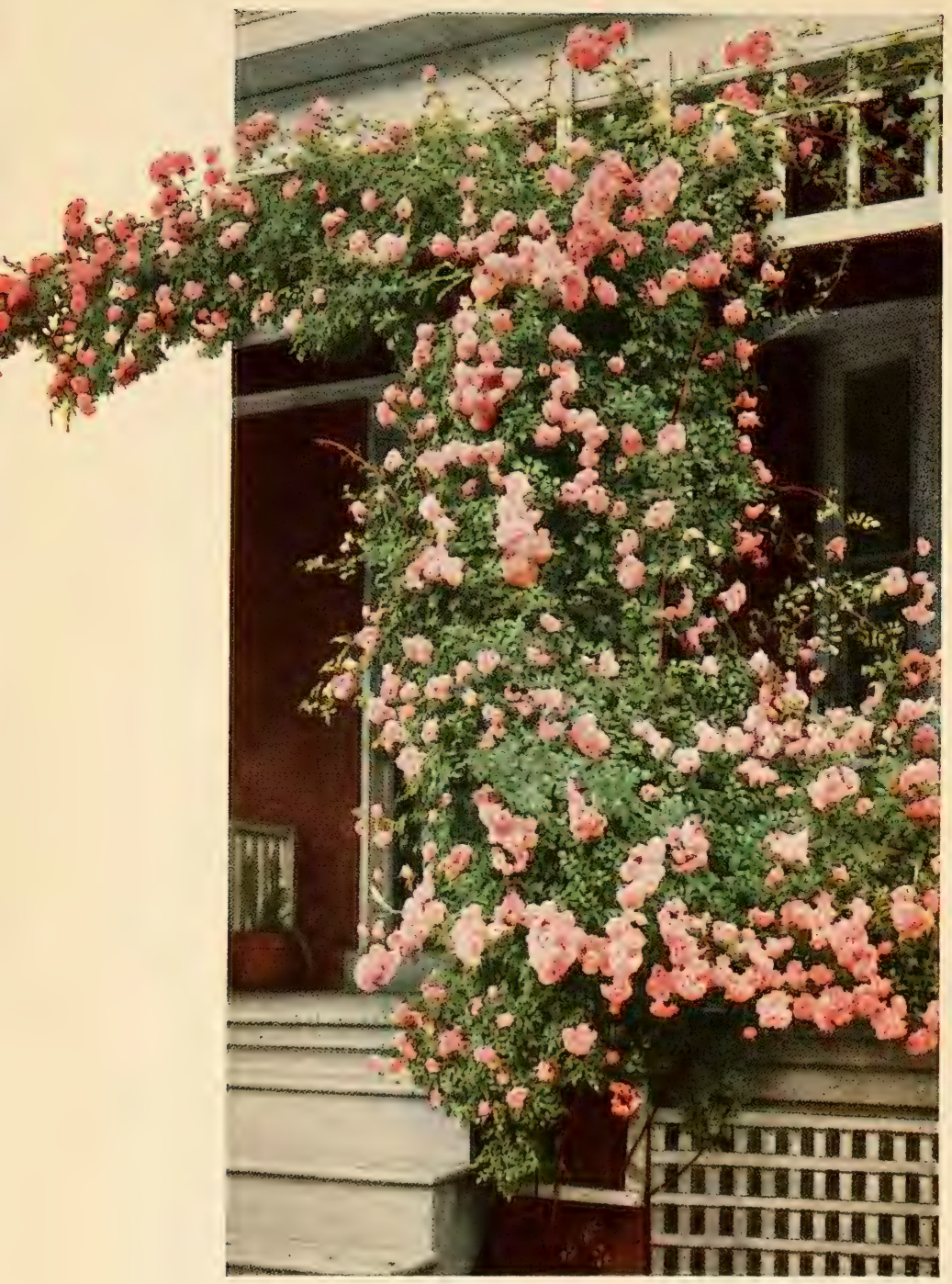

The list of Hardy Climbing Roses has been wonderfully enriched during the last fifteen years by the addition of such varieties as DOROTHY PERKINS (as pictured above); also White Dorothy and Excelsa, or Red Dorothy.

Their long, willowy branches, easily trained over almost any object, will, with reasonable care and nourishment, often attain a length of 20 feet in one season. 
NEW CENTURY. H.R. Flowers clear flesh-pink with light red center; deliciously sweet fragrance, like the wild rose. Extremely hardy。 Hedge, bush, or garden. Prune 6.

OPHELIA. H.T. Flowers salmon-flesh color, shaded with rose. Garden, bedding, cut-flower. Prune 2. (See illustration, page 49.)

ORLEANS. P. Flowers vivid rosy crimson. Garden, bedding, edging. Prune 3.

PAUL NEYRON. H.P. Flowers deep rose; fragrant; opens flat. Vigorous. Bedding, garden. Prune I for Ex., 3 for Q.

PAUL'S SCARLET CLIMBER. H.W. Flowers vivid scarlet. Vigorous; very fine. Porch, arch, pergola, wall, etc. Prune 7.

PERLE DES JARDINS. T. Flowers deep yellow; very Iarge, fuII, and fragrant. Garden, bedding. Prune 2. (See illustration in color, page 32.)

PERSIAN YELLOW. A.B. Flowers deep, rich, golden yellow. Garden, bush, hedge. Prune 6. (See illustration in color, page 63.)

PHARISÄER. H.T. Flowers rosy white, shaded with salmon. Vigorous. Garden, bedding, cut-flower. Prune 2.

PHILADELPHIA RAMBLER. Mult. Flowers intense crimson; double; in Iarge clusters. Very vigorous. Arch, porch, etc. Hardy. Prune 6-, $7+$.

PRINCE CAMILLE DE ROHAN. H.P. Flowers velvety crimson; Iarge. Vigorous. Bedding. Prune 2 for Ex., 3 for Q.

QUEENS SCARLET. C. Flowers rich velvety scarlet; size medium. Constant in bloom. Garden, bedding. Prune 3.

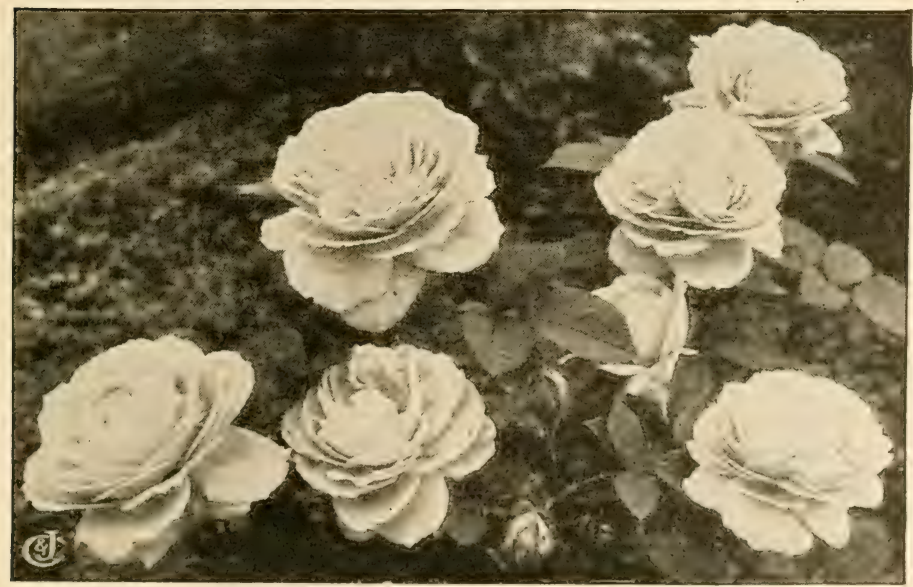

Mrs. John Laing (see page 57) 


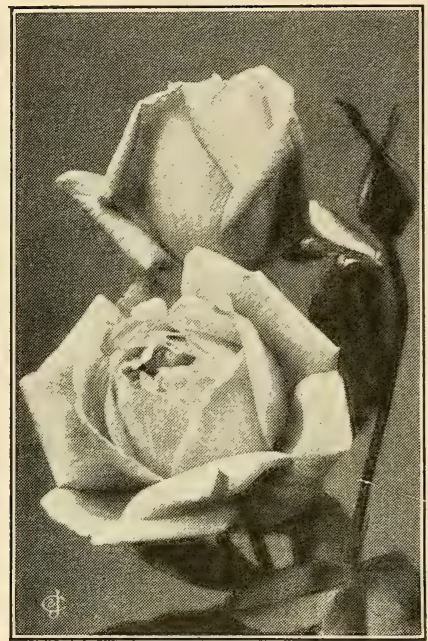

Rayon d'Or

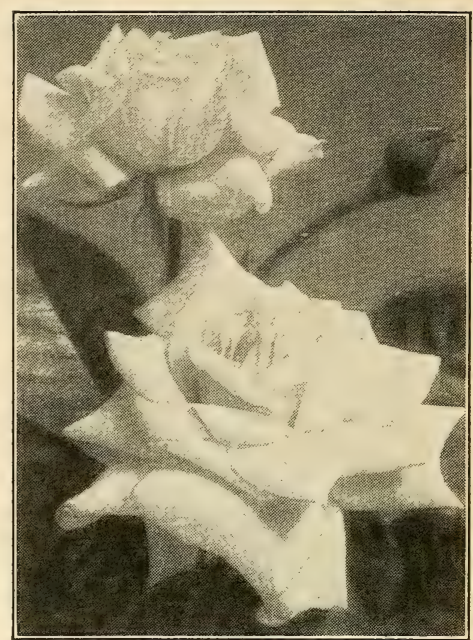

Kaiserin Auguste Victoria See page 50

RADIANCE. H.T. Flowers rosy carmine and pink. Fine for mass planting. Garden, bedding. Prune 2.

RAYON D'OR. Per. Flowers rich yellow, turning to sunfloweryellow. Foliage very fine. Vigorous. Garden. Prune 3. (See cut.)

RED RADIANCE. H.T. Flowers clear cerise-red. Vigorous. Garden, bedding. Prune I for Ex., 3 for Q.

ROGER LAMBELIN. H.P. Flowers glowing crimson with pure white around the edge of each petal. Unique. Garden, bedding. Prune I for Ex., 3 for Q.

RUBY QUEEN. H.W. Flowers ruby, with white center; large; double; in clusters. Vigorous. Pergola, pillar, etc. Prune $6,7+$.

RUGOSA ALBA. R. Flowers snow-white; large; single. Free bloomer. Very vigorous. Bush, hedge. Prune 6.

RUGOSA RUBRA. R. Flowers rosy crimson; large; single. Free bloomer. Very vigorous. Bush, hedge. Prune 6.

SAFRANO. T. Flowers apricot-yellow; fragrant; semi-double. Constant bloomer. Vigorous. Bedding, garden. Prune 3.

SHOWER OF GOLD. H.W. Flowers deep golden yellow, borne in fine trusses. Beautiful, vivid, glossy green foliage. Very vigorous. Arch, pergola, porch, etc. 'Prune 6, 7 -.

SILVER MOON. H.W. Flowers snow-white; very large; single. Very vigorous. Arch, pergola, porch, etc. Prune 7. 


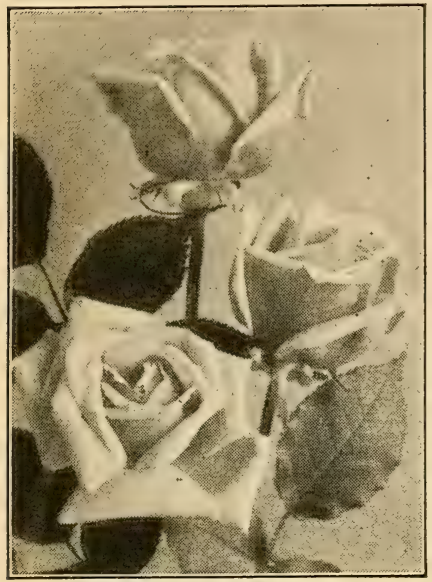

Mme. Melanie Soupert See page 53

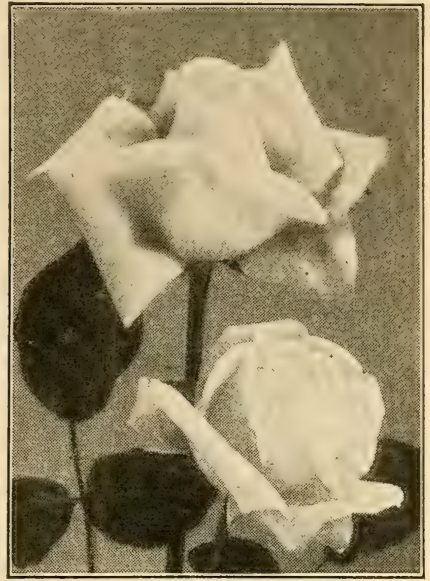

Mrs. A. R. WaddeII See page 57

SIR THOMAS LIPTON. H.R. Flowers pure white; fragrant. Constant bloomer. Leaves beautiful. Very hardy. Vigorous. Hedge, bush. Prune $5,7+$.

SOLEIL D'OR (Sun of Gold). Per. Flowers reddish gold, orange-yellow, nasturtium-red, and rosy pink; spicy orange fragrance. Garden, bedding. Prune 4.

SOUV. DE GUSTAVE PRAT. H.T. Flowers clear light sulphuryellow. Garden, bedding. Prune 2.

SOUV. DE LA MALMAISON. Bou. Flowers Iovely creamy flesh with rose center, elegantly shaded. Garden, bedding. Prune 3.

SOUV. DE PIERRE NOTTING. T. Flowers apricot-yellow, shaded orange. Garden, bedding. Prune 2.

SOUV. DU PRESIDENT CARNOT. H.T. Flowers shell-pink, tinted with fawn; large and full. Garden, bedding, cut-flower. Prune 2.

SUNBURST. H.T. Flowers intense orange-copper and golden yellow. Extra fine. Garden, bedding. Prune 2.

SWEETBRIAR (R. rubiginosa). S.B. Flowers pink; single. Foliage delightfully fragrant. Vigorous. Hedge, bush. Prune $6,7+$.

TAUSENDSCHÖN. Mult. Flowers white to deep pink. Very vigorous. Has few thorns. Fine. Porch, arch, etc. Prune 6, 7-. (See illustration in color, page 78.)

TIP-TOP (Baby Doll). P. Flowers pink, yellow gold, and Iavender combined. Dwarf grower. Bedding, edging. Prune 5. 


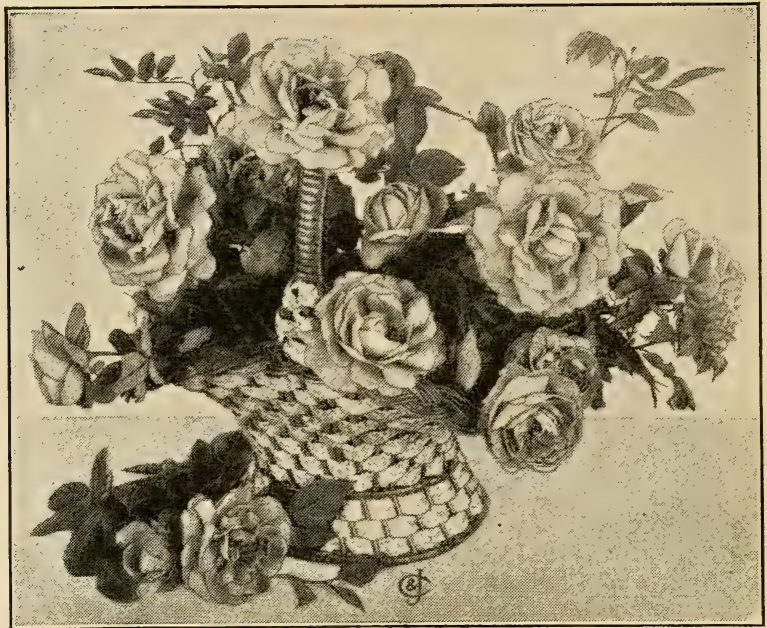

A tasteful arrangement of UIrich Brunner roses

ULRICH BRUNNER. H.P. Flowers rich red; fragrant; petals broad, round, thick. A standard variety. Vigorous. Garden, bedding, and standard. Prune I for Ex., 3 for Q. (See illustration in color, page 94.)

VIRIDIFLORA. C. Flowers with curious green petals, like a bunch of calyxes. Fine for St. Patrick's Day. Blooms freely. Garden. Prune 2.

WICHURAIANA. W. Flowers pure white; single. Leaves glossy, free from insects. Will grow anywhere. Splendid for holding banks from washing. Vigorous. Creeping. Prune $6,7+$.

WILLIAM ALLEN RICHARDSON. N. Flowers coppery yellow, tinged with carmine; deliciously fragrant. Not hardy. Splendid for the South. Vigorous. Porch, pillar. Prune 5.

WM. R. SMITH. T. Blush-pink; large; full. Vigorous grower. Garden, bedding. Prune I for Ex., 3 for Q. (See illustration, page 52.)

WILLIAM SHEAN. H.T. Flowers pure pink with delicate ochery venation; very large. Vigorous. Bedding, garden. Prune 3.

WILLOWMERE. H.T. Flowers rich shrimp-pink, shaded yellow in the center. Garden, bedding. Prune 4.

YORK AND LANCASTER. Damask. Flowers striped red and white. Very hardy. A very old and rather rare rose. Associated with the "Wars of the Roses." Garden. Prune 4. 'See illustration, page 7.) 


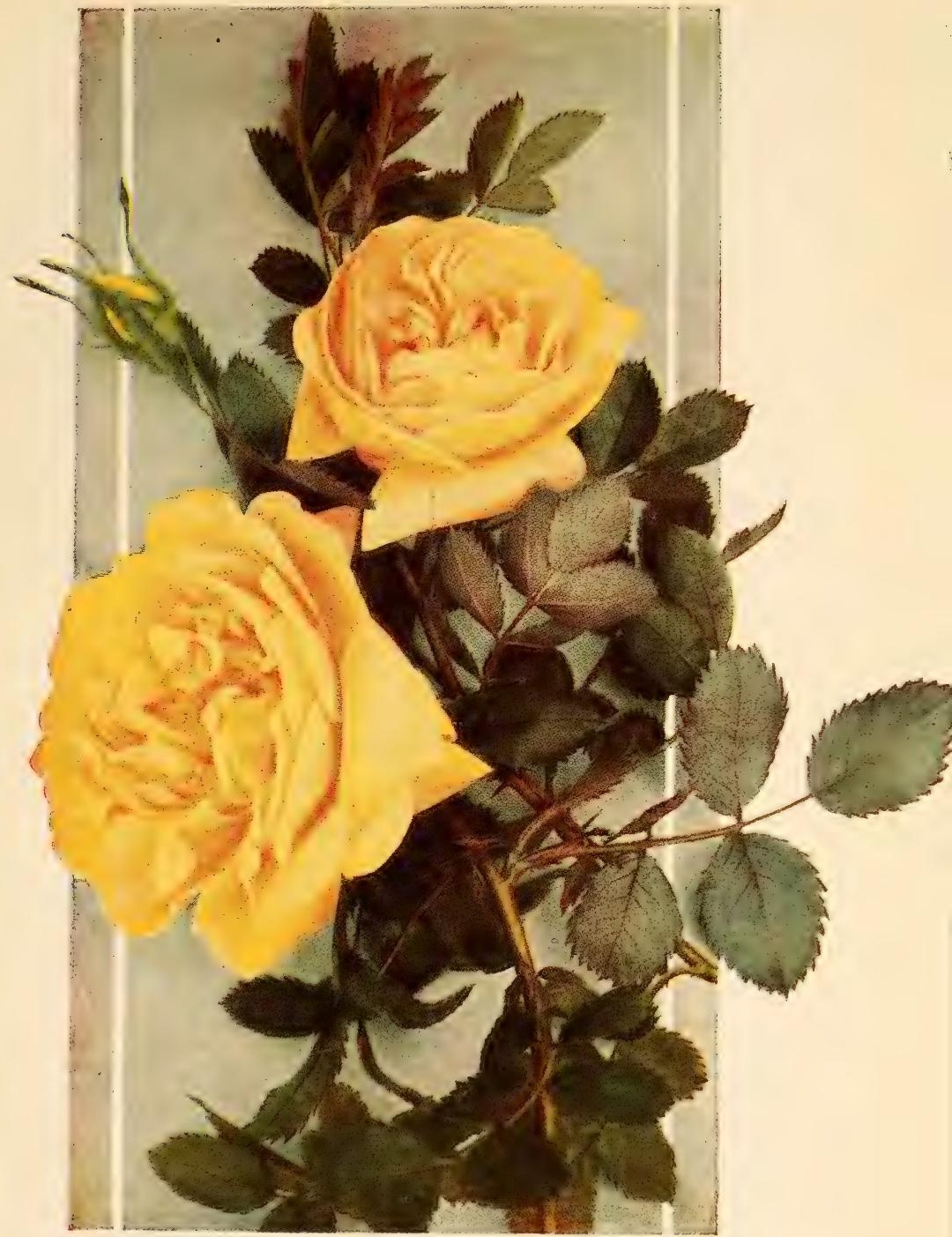

The beautifuI PERSIAN YELLOW Rose is commended highly, especially to those living in the colder sections of our country.

Its rich coloring and hardiness, combined with its early season of bloom and fragrant young foliage, give it a value among Roses comparable to the value of gold among metals.

A cousin to this Rose is HARISON'S YELLOW; like it in color but less double in bloom and more able to care for itself wherever planted. Both bloom earlier than even the Rugosas though not so early as HUGONIS. 


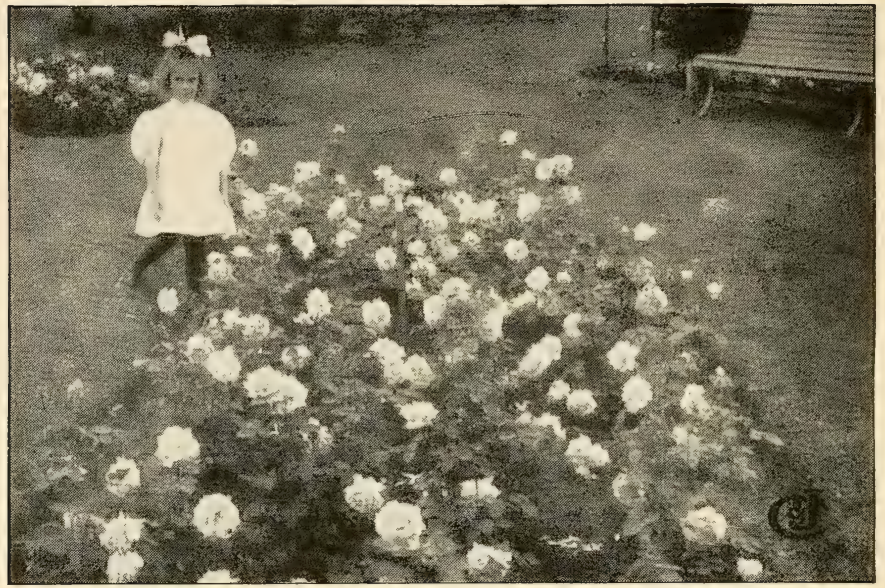

La France. Beautiful on the lawn; just as fine in vases

\section{Roses for Various Purposes and Uses Twelve Star Varieties}

In selecting the best roses, there are so many qualities to be considered that it requires a large collection and unusual opportunities to watch and study them under every possible condition they are likely to encounter. We have been fortunate in having unusual facilities for this experimental work. Furthermore, our observation extends over a long period of years, during which, each season, we have obtained and tried out all new sorts of promise, and thus aim to have the best obtainable constantly on trial. We also travel extensively and visit rose-gardens in many states of the Union. Due regard has been given to the published experiences of other dependable rose-lovers, in reaching our own conclusions.

To pass our severe test, a rose must prove itself a vigorous grower and an abundant bloomer, and must also excel its rivals either in size, color, form, fragrance, or habit.

So many friends ask us to select their roses that we believe they must have read Pemberton's advice. (See page 38.) 
These pages answer your questions before you ask them; they save you the expense of experiments; and, if you do your part, you can count on a reward of good bloom.

Columbia (H.T.). Pink.

Duchess of Wellington (H.T.). Yellow.

Frau KarI Druschki (H.P.). White. General MacArthur (H.T.). Red. Gruss an Teplitz (H.T.). Red.

Kaiserin Auguste Victoria (H.T.). White.
Los Angeles (H.T.). Pink.

Prince Camille de Rohan (H.P.). Red.

Radiance (H.T.). Pink.

Red Radiance (H.T.). Red.

Sunburst (H.T.). Yellow.

White Maman Cochet (T.). White.

\section{Twelve Cold-Country Roses}

Here are roses selected from among those that live outdoors over winter and thrive in localities north of the Iatitude of New York and Chiçago. These laugh at zero weather.

Conrad F. Meyer (H.R.). Pink. Frau Karl Druschki (H.P.). White. George Arends (H.P.). Pink.

Gloire de Chedane Guinoisseau (H.P.). Red.

Gloire Lyonnaise (H.P.). Cream. Hugh Dickson (H.P.). Red.
May Queen (H.W.). Pink.

Mrs. John Laing (H.P.). Pink.

Paul Neyron (H.P.). Pink.

Sir Thomas Lipton (H.R.). White. Souv. de P. Leperdrieux (H.R.). Red.

UIrich Brunner (H.P.). Red.

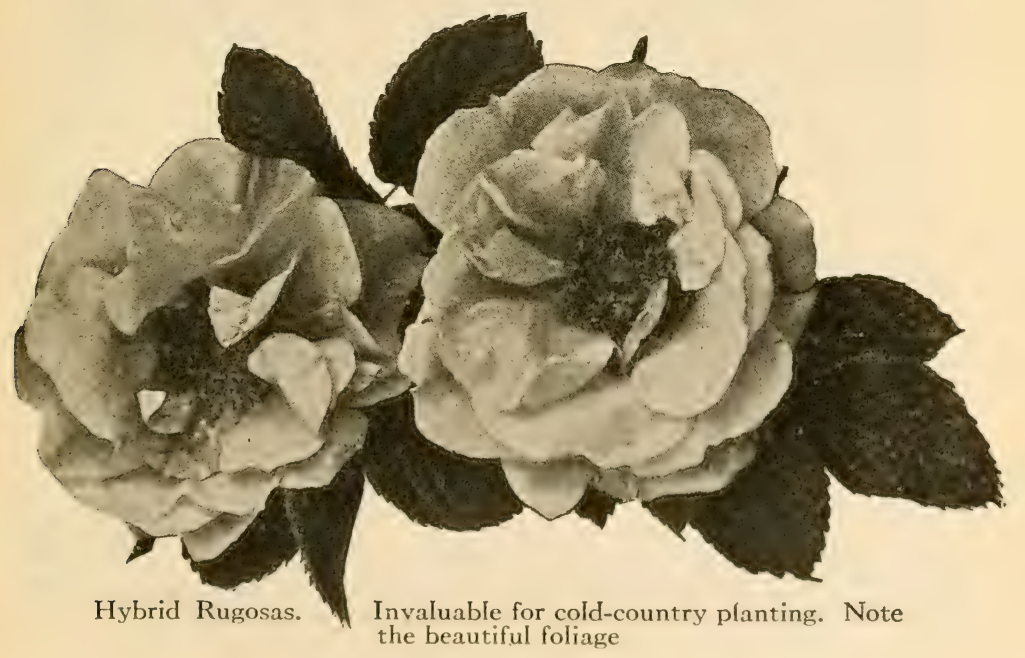




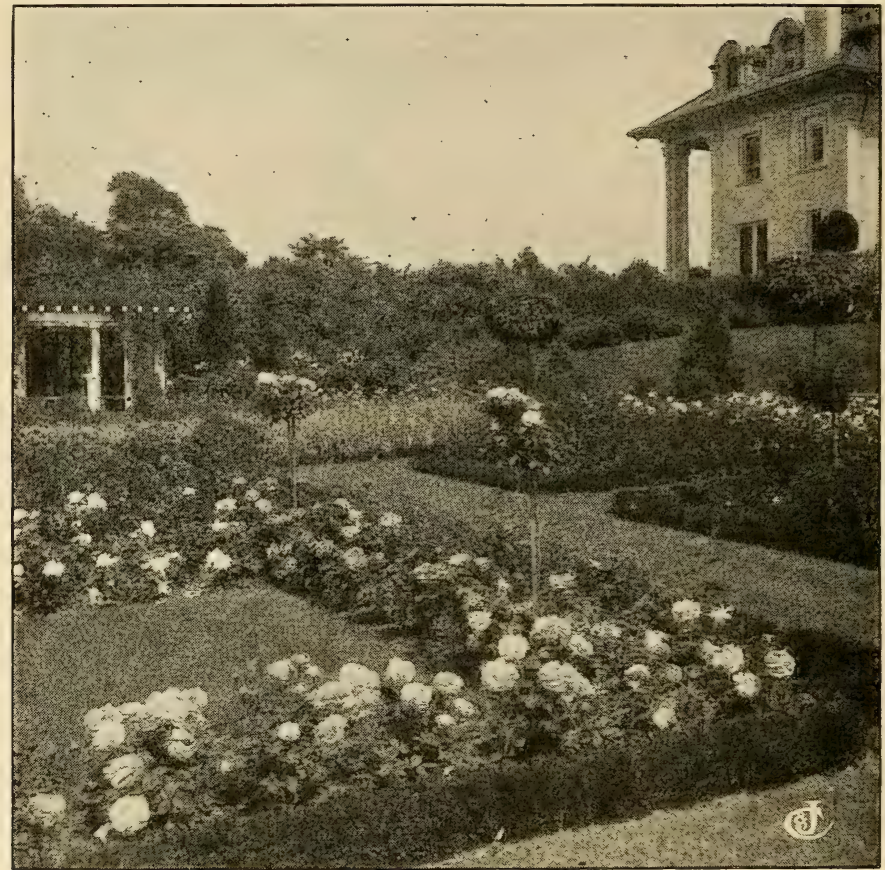

Nearly every home may have a dozen bushes like these

\section{Twelve Sunny South Roses}

If you live on the sunny side of the frost-line and wish a set of superior sorts for a warm country, here are twelve that we know you will find supremely satisfying.

These are our favorite twelve in a climate where there is little danger from frost. They will winter well as far north as Washington, D. C.

Countess of Gosford (H.T.). SaImon.

Duchess of Wellington (H.T.). Yellow.

Hadley (H.T.). Red.

Hoosier Beauty (H.T.). Red.

Maman Cochet (T.). Pink.

Marie Van Houtte (T.). Tinted.
Mme. Melanie Soupert (H.T.). Yellow.

Mrs. B. R. Cant (T.). Red.

Radiance (H.T.). Pink.

Safrano (T.). Yellow.

Sunburst (H.T.). Yellow.

White Killarney (H.T.). White。 
Climbing Roses That Will Cover Quickly, Trellises, Porches, Buildings, Etc.

Every home has room for a few climbers, because vines around a house decorate it as nothing else does, and to have vines that will hand you forth roses-imagine the pleasure of that!

Where you live makes a difference; roses that will grow to cover your house with bloom in northern New England are not the kinds to do the same in the sunny South. So, think of these things when you order, or, better still, leave it all to your grower, who will select to suit your home and climate. For example, here are three sets, each one good for the section indicated. Order accordingly, and you will get pleasing results.

(See list of climbing roses recommended for this purpose on page 68.)

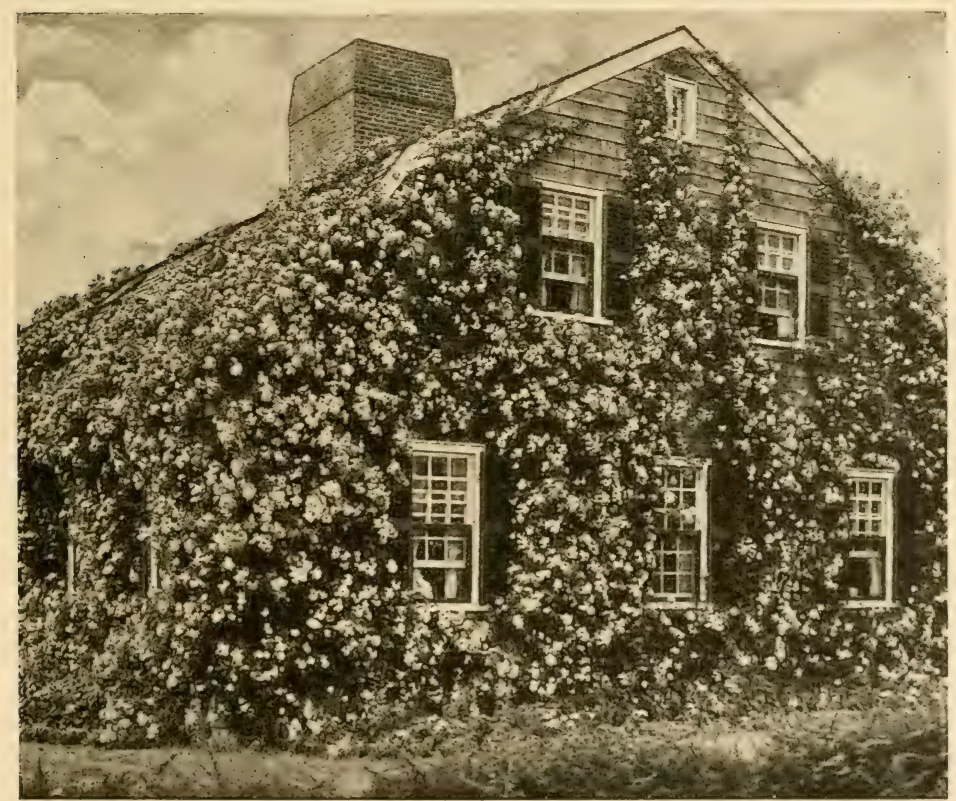

Dorothy Perkins roses in cold New England, growing over a cottage of Thos. W. Lawson, Dreamwold, Massachusetts. 
We recommend the following roses for the uses described on the preceding page:

For a Warm Climate-Everblooming Climbers-

Climbing Cruss an Teplitz. Red . . . . . . . . . 49

Mrs. Robert Peary. White . . . . . . . . . . . . . . . 57

Marechal Niel. Yellow . . . . . . . . . . . . . . 56

Climbing Pink Maman Cochet. Pink . . . . . . . . . . 56

For a Temperate Climate (latitude of Pbiladelpbia and New' York)-

Dorothy Perkins. Pink . . . . . . . . . . . . . 47

Excelsa (Red Dorothy). Red . . . . . . . . . . . . . . . 47

White Dorothy Perkins. White . . . . . . . . . 47

Mrs. Emily Gray. Yellow . . . . . . . . . . . . . . . 57

For a Cold Climate (where winters are long and severe)-

Dr. W. Van Fleet. Pink. . . . . . . . . . . . 47

Mary Lovett. White . . . . . . . . . . . . . . . . . . 56

Ruby Queen. Red . . . . . . . . . . . . . . 60

Tausendschön. Pink and white . . . . . . . . . . . . . 6I

Archways, Arbors, Summer-Houses, Pergolas, and for Beautifying Boundaries, Fences, Etc.

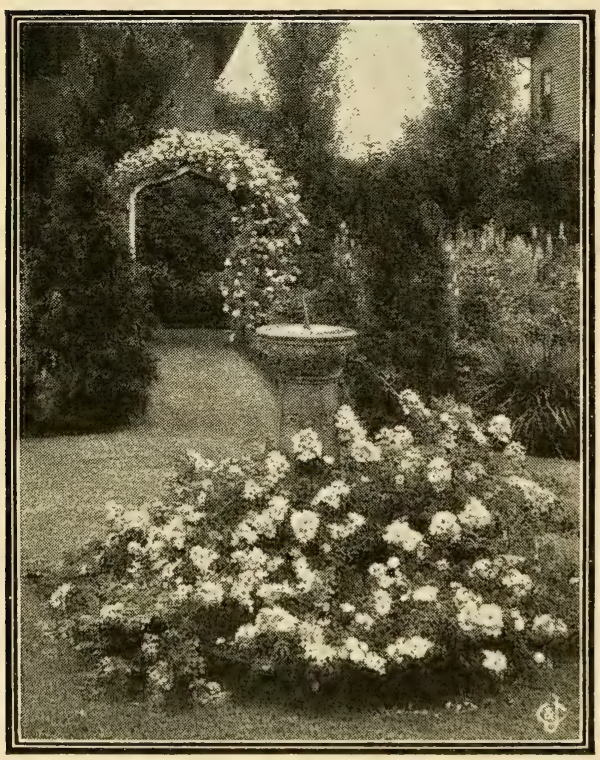

Effective uses of Hybrid Wichuraianas
Certain roses Iend themselves admirably to being trained over objects on which they can have support. The best kinds for such a purpose, we think, are:

Dorothy Perkins. Pink . . . 47 Ruby Queen. Red 60 American Pillar, Single. Pink. 44 Excelsa (Red Dorothy Perkins). 47 Tausend̊schön. Blush . . . . 6 I Aviateur Bleriot.

Yellow ... 44

Quite as pretty an effect may be had with certain other kinds by 


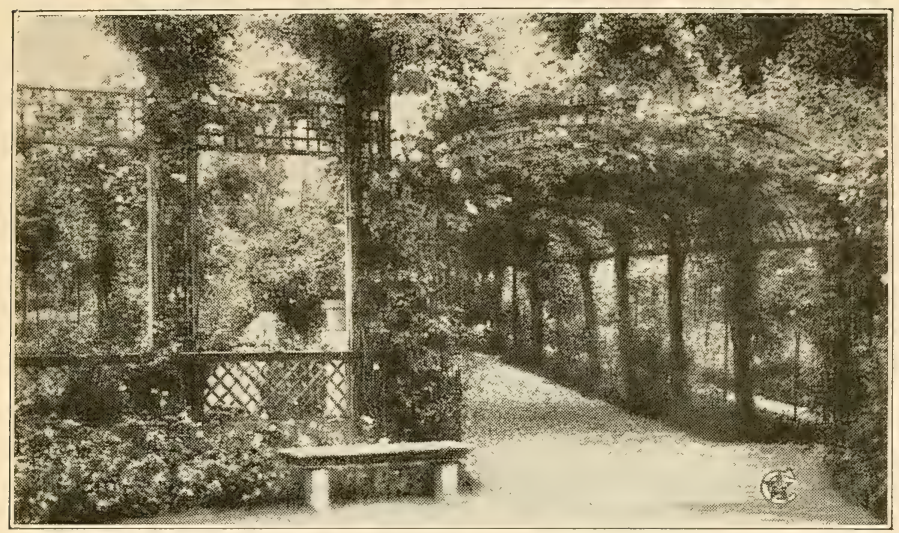

A lovely spot in the famous Gravereaux Rose-garden near Paris

allowing them to grow over a fence, as shown on page $7 \mathrm{I}$. Their willowy vine-like branches are very graceful, the foliage is shiny and almost evergreen, giving these the advantage over the Ramblers of being attractive even when not in bloom and almost the entire year.

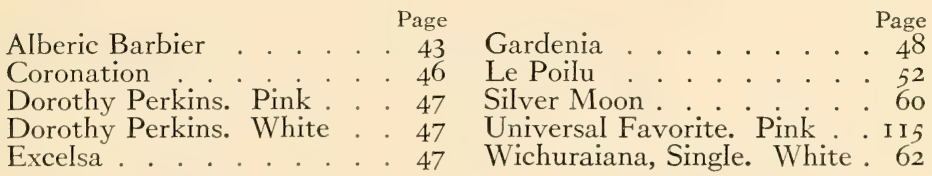

The above-mentioned roses flower during one period of the year only, but are hardier for cold climates than the following, which, if well cared for and properly nourished, will continue to produce some bloom during summer and autumn.

Climbing Gruss an Teplitz. Red . . . . . . . . . . . . 49

Climbing Killarney. Pink . . . . . . . . . . . . . . . I Is

Climbing Lady Ashtown. Pink . . . . . . . . . . . . . 50

Climbing Mme. Caroline Testout . . . . . . . . . . . . . II

Climbing Pink Maman Cochet . . . . . . . . . . . . . . . . 56

Climbing White Killarney . . . . . . . . . . . . . . . II5

Reine Marie Henriette . . . . . . . . . . . . . . . . II5

Shower of Gold. Yellow; shiny foliage . . . . . . . . . 60 


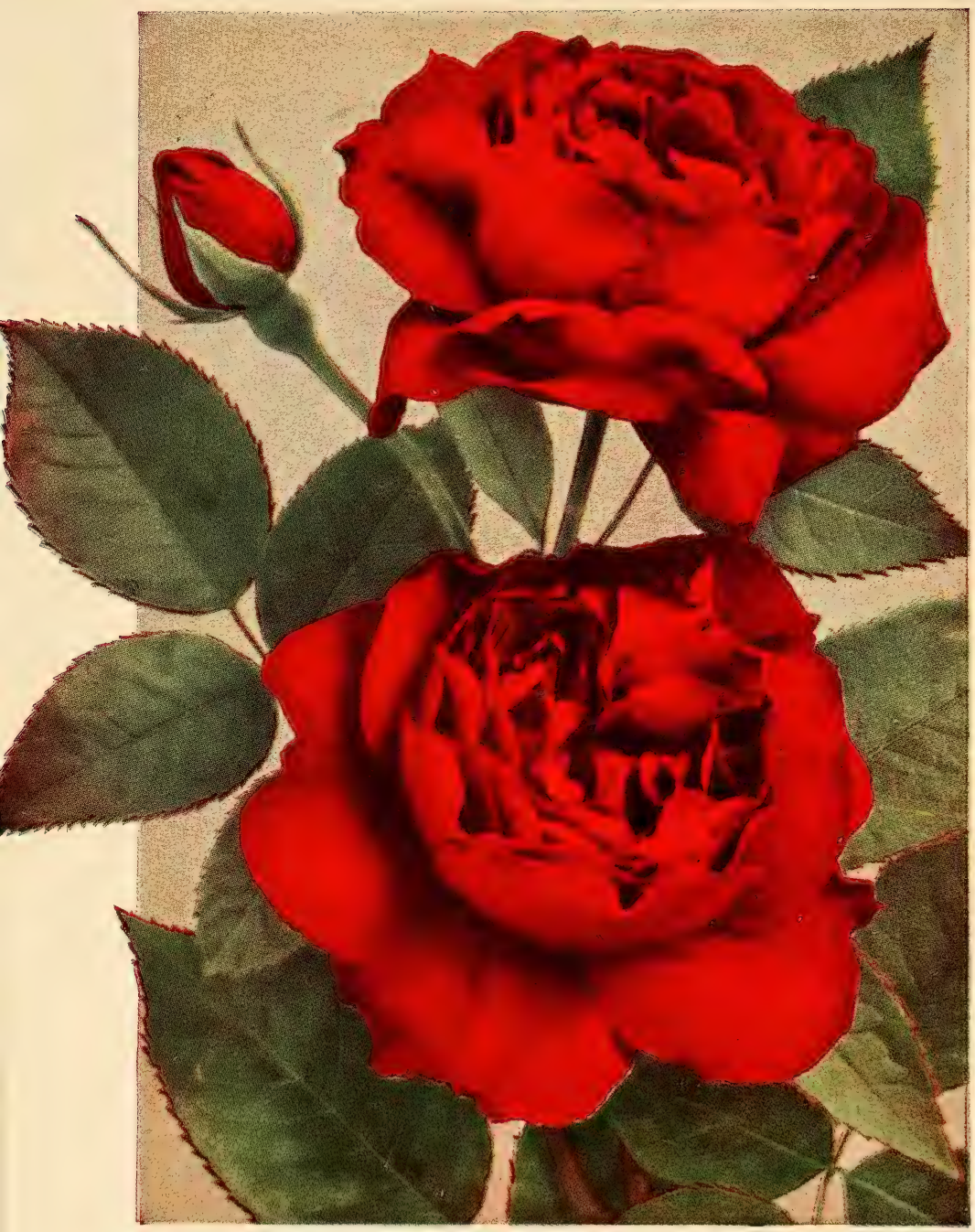

THE STANDARD HYBRID PERPETUAL, GEN. JACQUEMINOT

Do you know the quaint custom that still holds in one of the country towns of Pennsylvania, whereby, in accordance with the will of Baron Stiegel, there is paid for the church property, with an appropriate anniversary celebration, an annual rental of one red Rose?

No other Rose can be counted upon for this service so surely as the dear old favorite "Jack." 


\section{For Covering a Bank, Stumps, or Like Objects}

The Wichuraiana is an ideal cover rose. It is remarkably free from both insects and disease and looks clean and fresh the entire year.

It bears bright berries, which the birds like. Enterprising railroad companies use Wichuraianas to hold embankments in place; they also add to the roadside beauty.

Gardenia (Hardy Marechal Niel). Yellow. (See page 48.)

Coronation. (New.) Pink. (See page 46.)

Universal Favorite (Double Pink Memorial). (See page I1 5.)

Wichuraiana (Single). White. For growing on banks. One plant of

Wichuraiana will easily cover 6 square feet of ground. (See page 62.)

Most of the Hybrid Wichuraianas are also well suited for covering purposes.

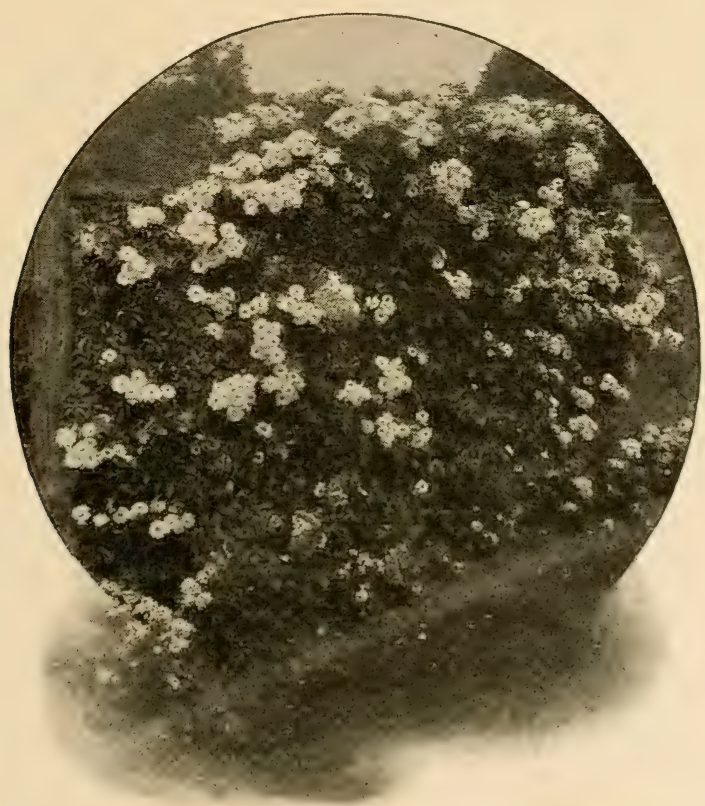

Here is a beautiful hint, easily and cheaply adopted by anyone whose fences are bare. See varieties mentioned above 


\section{For Screen Planting and Borders, or Beautifying the Unsightly}

Almost every lawn might be improved, if some uncomely object or portion in the rear were screened from view. The right kind of roses will do it, and give you something beautiful instead. There are two ways to do it: (I) put up a trellis and train over it the roses named on page $7 \mathrm{I}$; or (2) if it be a low screen, you need only to plant the tall, erect-growing Rugosa roses. And if you want a luxuriant growth, dig the ground deeply and give these roses plenty of rich nourishment.

Birdie Blye. Page Page Birdie Blye. Pink . . 44 Hugonis. Yellow . . . 50 Conrad F. Meyer. Silvery pink 46 May Queen. Pink . . . . 57 Christine Wright. Pink . . 46 Ruby Queen. Ruby-red . . 60 Harison's Yellow . . . . 49 Sir Thomas Lipton. White . . 61

These eight varieties, if set in one group, should be placed at least 2 to 3 feet apart.

Wonderfully pleasing effects may be obtained for screening out undesirable objects or views by the erection of trellis formations. These may be made of various designs and materials. Over these train the roses recommended on pages 68 and 69 .

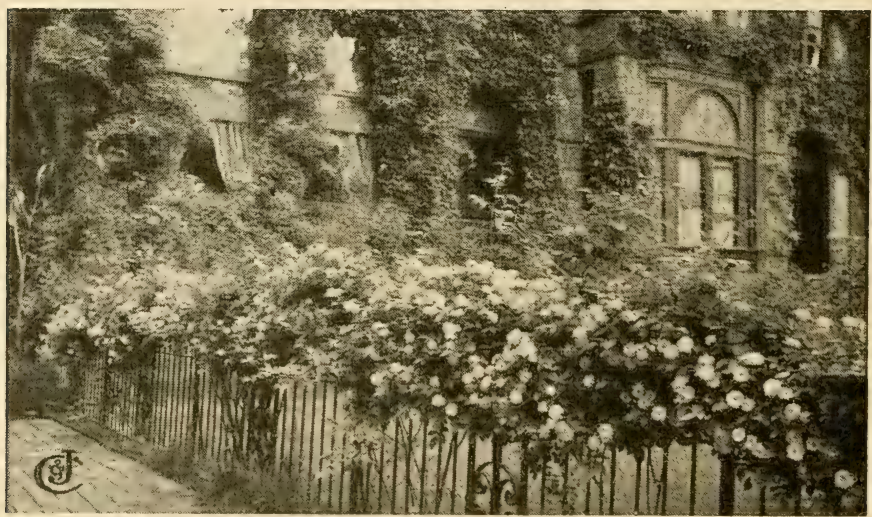

A tence made beautiful with Wichuraiana roses 


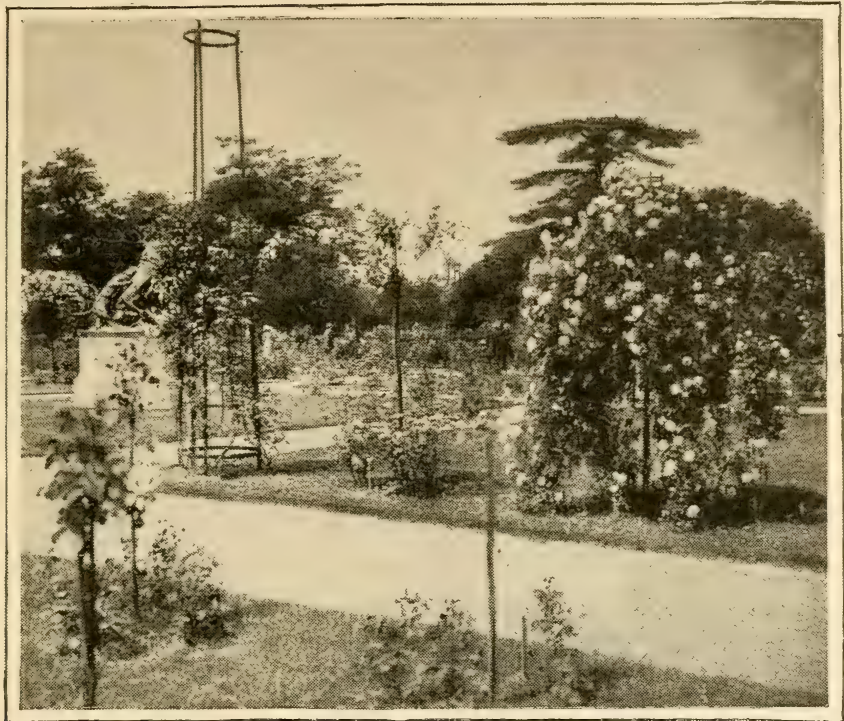

The tree Roses in the Bagatelle Gardens in Paris are much Iarger than are customarily seen in American gardens. Some of these are 12 feet high, having been budded with Wichuraianas that weep to the ground.

\section{Standard or Tree Roses}

Tree roses add a distinct touch of elegance to any rosegarden. They occupy but little space and are quite imposing. Along the sides of walks they produce an avenue effect. They look weIl in the center of a small bed or even appropriately placed in the perennial border.

Tree roses are produced by budding such climbing and bush roses as Dorothy Perkins or Gruss an Teplitz on the tops of heavy, erect, cane-like stocks. The bush roses may be kept shapely. The climbers will weep to the ground.

Tree roses in the past have been less used in this country than in Europe because they are harder to grow in our climate, where summers are sometimes hot and dry. To overcome this handicap you can wrap the tall, slender stalks with moss and keep that moist. Such care, with special winter protection, is likely to be well repaid. They are quite scarce. 


\section{Rose Hedges}

These boundary markers are certainly coming to be more and more popular as people learn about the splendid qualities of the Rugosa roses, Sweetbriars, or Altaica for this purpose. They are not neat, compact, and uniform in growth as is a hedge of California Privet, but the thick, bushy mass of glossy, crinkled foliage, especially of the Rugosa, gives a particularly fine appearance. They are perfectly hardy in the coldest winters and are more valuable because the foliage is not troubled with either insects or disease.

In warmer countries, or even in our own latitude, a single row of a free-flowering, erect, bushy rose is sure to be pretty and very satisfactory where one wishes simply to mark a boundary, as, for example, between the vegetable- and flowergarden. For this purpose, Gruss an Aachen, (see page 49) is excellent. The small-flowered Polyanthas are also popular, especially Baby Rambler, Marie Pavie, and Baby Dorothy. The list could readily be extended, and each one would be well worth planting. (See list of Polyanthas, page i I3.)

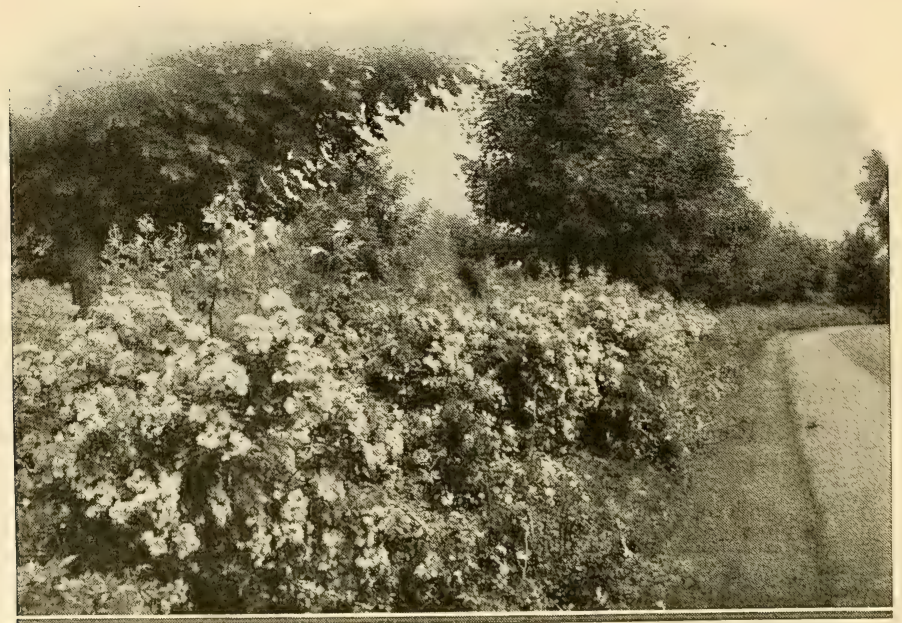

Hybrid Wichuraianas, if given some support, make an excellent hedge 


\section{Roses for the Cemetery}

For some cemeteries we recommend roses that almost care for themselves - the Wichuraiana type. They creep like ivy and make a mat of shiny foliage which is green for eleven months.

Next to these, we like the dwarf, compact-growing, freeflowering Polyanthas, especially the White Baby Rambler, Gruss an Aachen, Marie Pavie, and Echo. If you can care for bush roses, select from the "Best Yet" sets, according to locality. If you want some of the sturdiest growers obtainable, choose from this list:

Cone

Conrad F. Meyer (H.R.). Pink . . . . . . . . . . 46

Sir Thomas Lipton (H.R.). White . . . . . . . . . . . . 6r

Frau Karl Druschki (H.P.). White . . . . . . . . . . . 48

Mme. Plantier (Alba). White . . . . . . . . . 53

\section{Single Roses}

These are an interesting group in themselves and represented in various classes. The single Irish roses are best among the Hybrid Teas.

Irish Elegance (see cut)

Irish Brightness

Irish Fireflame

The species are most interesting specimens, among which are Xanthina, Moyesii, and Hugonis. One of the largest flowered of the subspecies is Altaica (page rog)

For Edging Beds See Polyanthas, p. II3.

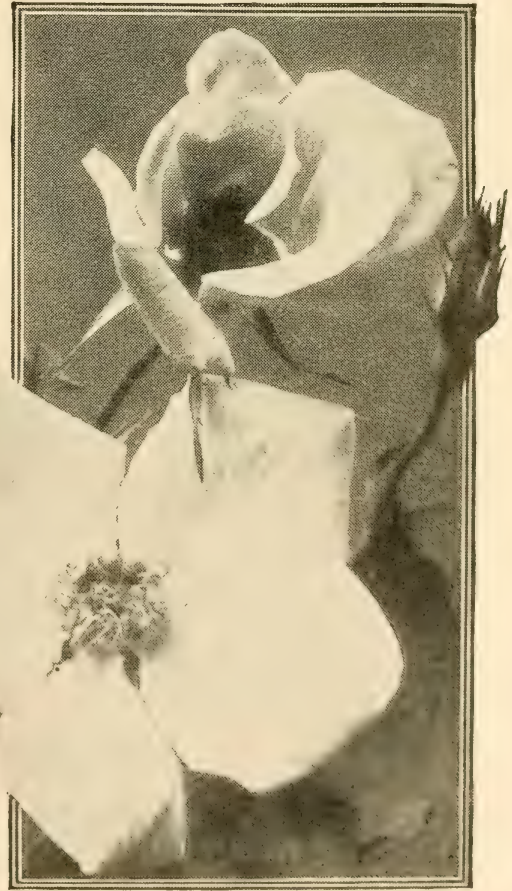




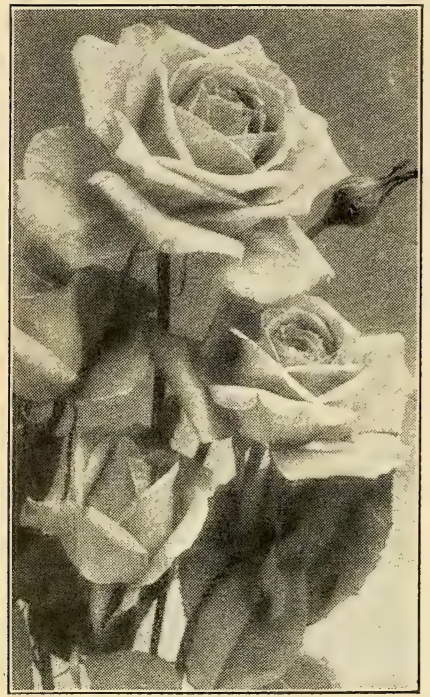

Columbia (see page 46 )

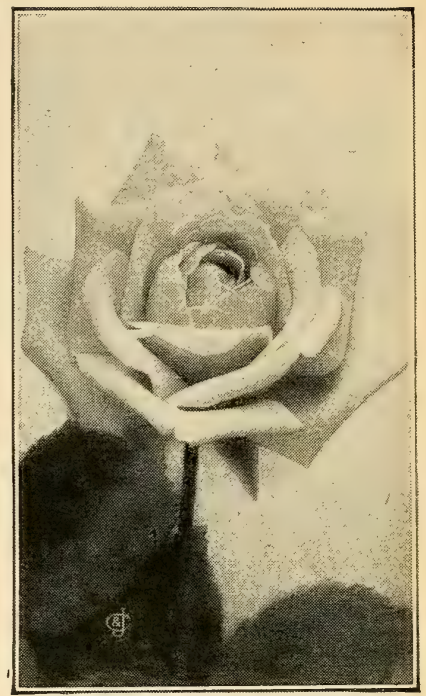

Radiance (see page 6o)

\section{For "Forcing" under Glass or for Indocr Winter Bloom}

These varieties are grown by professional florists in glasshouses where they can with nicety regulate the supply of heat and moisture, to produce the long-stemmed "beauties" seen in florists' windows. While a greenhouse or conservatory is a wonderful help, indeed essential for best results, some people have wonderful success even in their homes by growing roses where there is plenty of light and air. Both coal-gas and too dry air are injurious to plant-life and are to be carefully guarded against.

The list of cut-flower roses most popular in the general use is not a long one but is liable to change by reason of the great demand among patrons for something new. At present the best are: Columbia, Premier, Red Columbia, Ophelia, Pilgrim, Double White Killarney, Mrs. Aaron Ward, Kil Iarney Brilliant, Sunburst, Mrs. Charles Russell, MIle. Cecile Brunner, Radiance, American Beauty, and Kaiserin Auguste Victoria. 


\section{Selections for Special Sections of the United States of America}

Those of our readers who live in the more thickly settled sections of our country will recognize, in the following, our dependence upon the modern scientific method of learning the "best roses" for certain Iocalities, i.e., the method of actually testing them. We have had the good fortune to visit personally and to know the rose experts in many sections, and they severally have been so kind as to give us the benefit of their valuable experience, each in the form of a list of roses they have found to thrive. We stand back of these recommendations. (See, also, pages 64 to 76 , inclusive.)

\section{For the Pacific Northwest}

Portland, Ore., is without question the rose-growing center of the Pacific Northwest. Nearly everybody there grows roses, and the city itself gives promise of having soon the finest municipal rose-garden in America. Among Portland's rose-growers we know of none more enthusiastic and better versed than Mr. J. A. Currey, Chairman of the American Rose Society's National Rose Test-Garden, to whom we are indebted for the following recommendations:

Columbia

Frau KarI Druschki

General MacArthur

Grange Colombe

Gruss an Teplitz

Hugh Dickson

\section{Twelve best roses for general cultivation}

Mme. Caroline Testout

Mme. Melanie Soupert

Maman Cochet

Ophelia

Richmond

UIrich Brunner

\section{Six best climbing or rambling roses}

American Pillar

Dorothy Perkins

Gloire de Dijon
Mme. Alfred Carriere

Mme. Caroline Testout, Climbing Wm. Allen Richardson

\section{Six best red roses for general cultivation}

Avoca

General MacArthur

Hugh Dickson
J. B. Clark

Richmond

UIrich Brunner 


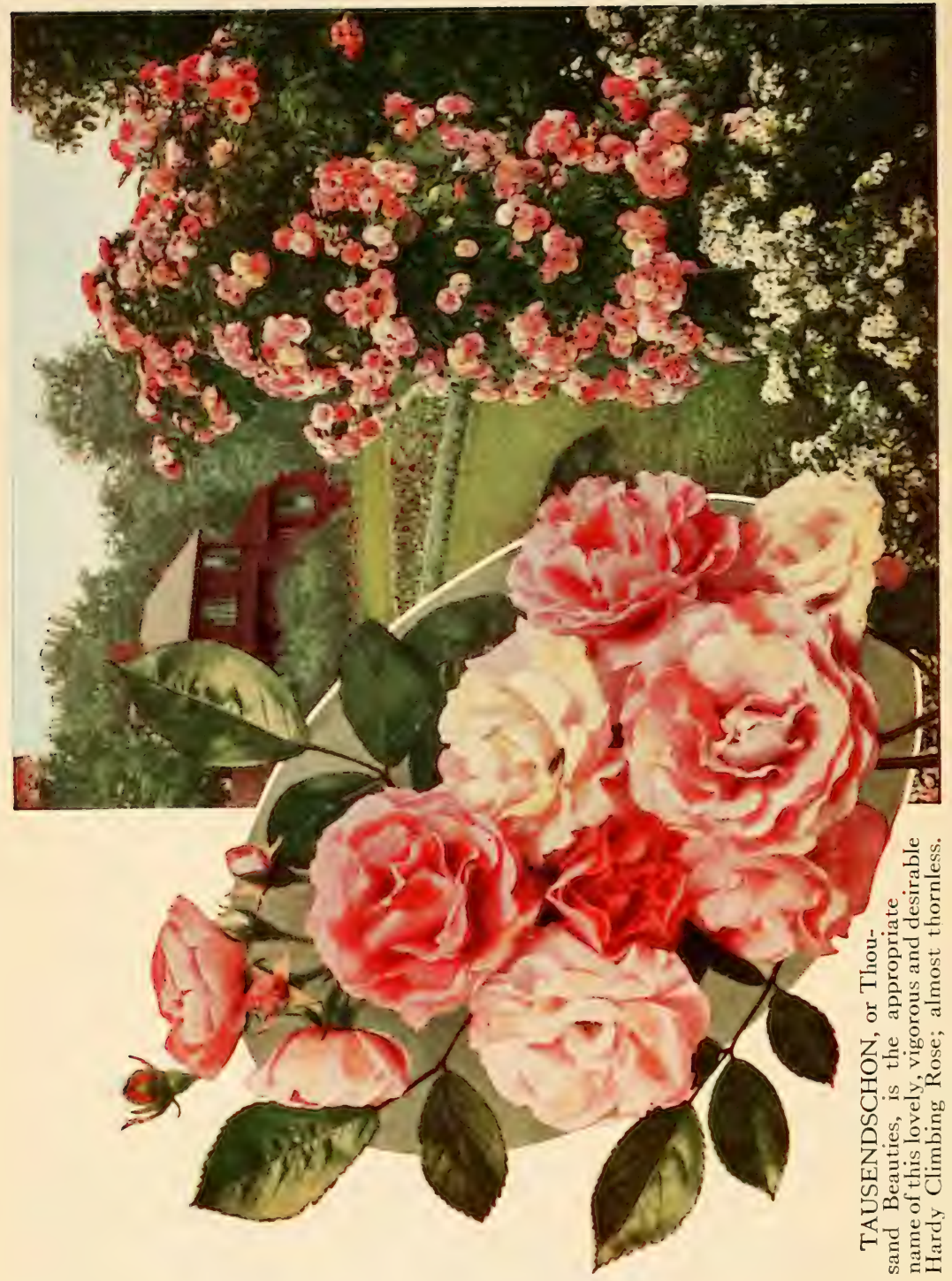


Roses for the Pacific Northwest, continued

Six best white roses for general cultivation

British Queen

Florence Pemberton

Frau KarI Druschki
Grange Colombe

Mme. Jules Bouché

Mrs. Foley-Hobbs
Columbia

Six best pink roses for general cultivation
Lady Ashtown

Mme. Caroline Testout
Maman Cochet

Miss Kate Moulton

Ophelia
Joseph Hill

Lady Hillingdon

Mme. Melanie Soupert
Six best yellow roses for general cultivation

Mme. Ravary

Mrs. Aaron Ward

Sunburst

\section{For Minneapolis and Vicinity}

Minneapolis has the largest public rose-garden in the Northwest, and Mr. Theodore Wirth, Superintendent of Parks, of Minneapolis, Minn., recommends for his section of the country the following list of roses:

\section{Hybrid Perpetuals}
Anna de Diesbach
Hugh Dickson
Baroness Rothschild
Captain Hayward
Clio
J. B. Clark
Jules Margottin
Louis Van Houtte
Frau KarI Druschki Marie Finger
General Jacqueminot Marshall P. Wilder
Mme. Gabriel Luizet
Mrs. John Laing
Paul Neyron
Prince Camille de Rohan
Tom Wood
UIrich Brunner

Heinrich Schultheis

\section{Hybrid Teas}

Aaron Ward

Alfred Colomb

General MacArthur

George Dickson

Gruss an Teplitz

Jonkheer J. L. Mock

Kaiserin Auguste Victoria

Killarney, Pink and Miss Cynthia Forde White
Lady Ashtown

Lady Ursula

La France

Laurent Carle

Mary, Countess of Ilchester

Maman Cochet, White and Pink
Mme. Caroline Testout

Mme. Jules Grolez

Radiance

Red Radiance

Souv. du President Carnot

Totote Gelos

Willowmere

\section{Climber Ramblers}

Crimson Rambler

Tausendschön. (See opposite page.) 


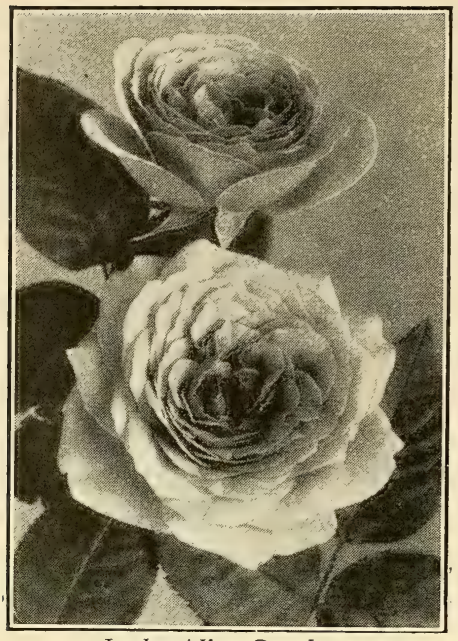

Lady Alice Stanley

Roses for Minneapolis and Vicinity, continued - Polyanthas

Abundance Clotilde Soupert

Gloire des Polyanthas Jessie

Marie Pavie

Mlle. Cecile Brunner

Mme. Norbert Levavasseur

Mme. Zelia Bourgeois

Mrs. W. H. Cutbush

Orleans

Primula

Triomphe Orleanais

White Clotilde Soupert

\section{Climbing Wichuraianas}

Dorothy Perkins Minnehaha Hiawatha Paradise La Fiamma The Farquhar Rose

\section{For Central New York State}

Rev. E. M. Mills, D.D., is president of the Syracuse (New York) Rose Society, and perhaps America's nearest prototype of Dean Hole, England's great rosarian of beloved memory. He recommends the following as the best collection of twenty-frve Hybrid Teas and Teas for Syracuse and vicinity, considering hardiness, variety of color, vigor of growth, and freedom of bloom.

\section{Hybrid Teas}

Antoine Rivoire

Chateau de Clos Vougeot

Columbia

Duchess of Wellington

Florence Pemberton

General MacArthur

Gruss an Teplitz

Killarney, Pink

Königin Carola

Lady Alice Stanley

Lady Ashtown

Laurent Carle

Mme. Jules Bouché

Mme. Melanie Soupert

Mme. Segond Weber

Miss Cynthia Forde

Mrs. Aaron Ward

Ophelia

Radiance

Sunburst

\section{Teas}

Harry Kirk

Lady Hillingdon

Marie Van Houtte

White Maman Cochet

Wm. R. Smith 


\section{For Roslyn and Northwest Long Island}

Admiral Aaron Ward*, in 1916, recommended the selection given below. It was based upon the following requirements: autumn blooms indispensable; weak growers barred; also plants of huge growth, like La Tosca or Gruss an Teplitz, except for use in mass effects; flowers to be full, no thinner than Pharisäer; climbers not included.

\section{Pernetianas}

Constance

Lyon Rose
Mme. Edouard Herriot

Willowmere
Teas

Mme. Antoine Mari

Mme. Jean Dupuy

Marie Van Houtte
Paula

Wm. R. Smith

\section{Hybrid Perpetual}

Frau Karl Druschki

\section{Bourbon}

Souv. de Ia Malmaison

\section{Hybrid Teas}

Augustine Guinoisseau

Amateur Teyssier

Chateau de Clos Vougeot

Dean Hole

Duchess of Wellington

Earl of Warwick

General-Superior Arnold Janssen

General MacArthur

George C. Waud

Gruss an Teplitz

Gustav Grunerwald

Joseph Hill

Königin Carola

Lady Alice Stanley

Lady Ashtown

Lady GreenalI

Laurent Carle

Lieut. Chauré

Mabel Drew

Mme. Abel Chatenay

Mme. Jules Bouché
Mme. Jules Grolez
Mme. Leon Pain
Mme. Melanie Soupert
Mme. Ravary
Mme. Segond Weber
Marquise de Sinety
Mrs. Aaron Ward
Mrs. Amy Hammond
Mrs. A. R. WaddeIl
Mrs. Charles Hunter
Mrs. Edward PoweII
Mrs. George Shawyer
Mrs. Harold Brocklebank
Mrs. Theodore Roosevelt
Pharisäer
Prince de Bulgarie
Radiance
Souv. du Pres. Carnot
St. Helena
Viscountess Folkestone

*Admiral Aaron Ward, a really great rosarian, died July 5, i9 8 . The notable introductions of the past four yoars would displace only a few from the list of roses he most prized. 


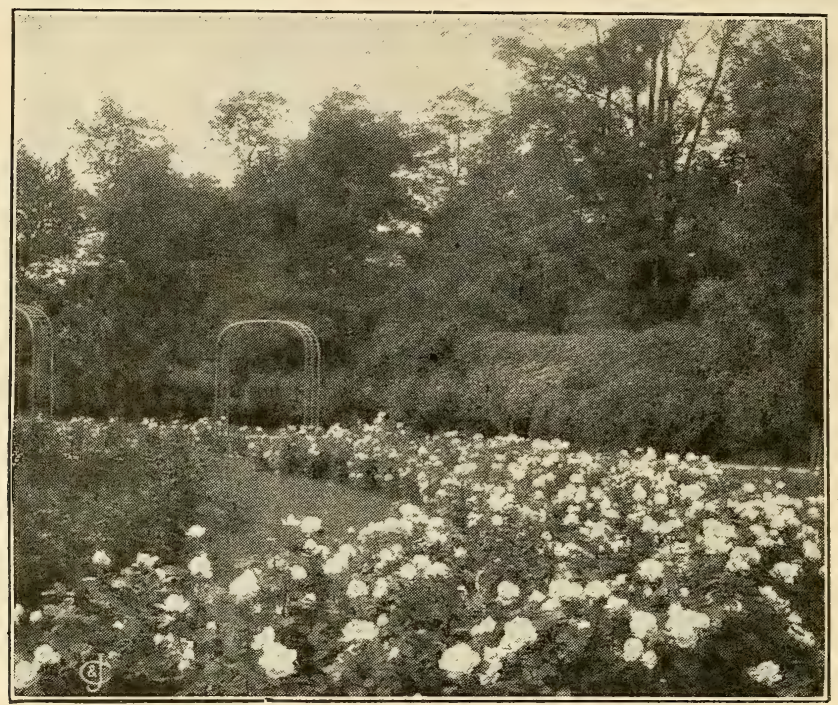

Rose-beds of one variety make a fine effect

\section{For Philadelphia and Vicinity}

Dr. Robert Huey, the eminent amateur whose success has been an inspiration to many others, and who is broadly recognized as an authority on garden roses, recommends the following varieties:

Antoine Rivoire

Betty

Duchess of Wellington

EIlen Willmott

- George C. Waud

Joseph Hill

Killarney

Lady Alice Stanley

Lady Ashtown

Laurent Carle

Los Angeles

Lyon

Mabel Drew

Mme. Edouard Herriot

Mme. Caroline Testout

Mme. Hector Leuillot

\section{Hybrid Teas}

Mme. Jules Bouché

Mme. Leon Pain

Mme. Melanie Soupert

Mme. Segond Weber

Mrs. Aaron Ward

Mrs. A. R. WaddelI

Mrs. Harold Brocklebank

Mrs. MacKellar

Ophelia

Pharisäer

Prince de Bulgarie

Radiance

Robert Huey

Viscountess Folkestone

Willowmere 
Roses for Philadelphia and Vicinity, continued

Baroness Rothschild

Captain Hayward

Frau Karl Druschki

George Arends

Oskar CordeI

Harry Kirk

Hugo Roller

Lady Hillingdon

Maman Cochet

Aviateur Bleriot

Christine Wright

Dorothy Perkins

Dr. W. Van Fleet

Elisa Robichon

\section{Hybrid Perpetuals}

Mrs. John Laing

Mrs. George Dickson

Susanne-Marie Rodocanachi

Ulrich Brunner

\section{Tea Roses (Hardy)}

Safrano

White Maman Cochet

Wm. R. Smith

\section{Climbing and Pillar Roses}

\section{For Washington, D. C., and Points South}

Dr. W. Van Fleet has for many, many years been a distinguished student of the rose. American Pillar, May Queen, Ruby Queen, Mary Lovett, Bess Lovett, Alida Lovett, Silver Moon, and Dr. W. Van Fleet are a few of his hybridizing. Now associated with the Department of Agriculture, he is hybridizing them to fit the needs of the American people. From such an authority do we offer the following list for warm climates:

\section{Pink}

Killarney, H.T.

Mme. Abel Chatenay, H.T.

Mme. Gabriel Luizet, H.P.

Maman Cochet, T.

Mrs. John Laing, H.P.

My Maryland, H.T.

Paul Neyron, H.P.

Radiance, H.T.

Wm. R. Smith, T.

\section{Yellow}

Etoile de Lyon, T. Lady Hillingdon, $\mathrm{T}$. Sunburst, H.T.
Excelsa

Gardenia

Hiawatha

Reine Marie Henriette

Tausendschön 


\section{For Chicago and the North}

By W. C. EGAN

Editor's Note.-People who live in the cold Northwest may think it useless to attempt growing roses, but, as Dr. Bailey says, "the success of the rose in this country is very Iargely a question of the selection of adaptable varieties." The Lake Fcrest section, on the west shore of Lake Michigan and north of Chicago, is typical of a large area to the north and west. In this section there is no one better able to speak from broad experience than W. C. Egan, the eminent horticulturist of Highland Park. In response to our request for a list of roses best suited to his cold country, he very generously sent us a contribution which, without further comment, we are most happy to present to our readers.

While the section bordering Lake Michigan from Chicago northward, called the North Shore district, is not a rosarian's paradise, we can have roses from early June until frost. This we can accomplish with but little care, except in the case of the Hybrid Teas, which require proper attention. Given this, they flood us with a shower of bloom that makes them worthy of cultivation, even if we treat them as annuals, and plant fresh stock each year. "Expensive!" you say. Well, yes, to a certain extent; but so are bedding-plants, and babies, and automobiles; but the results in all cases are worth the money. Some spend money Iavishly for winter decorations that fade in the night. The same amount, spent for Hybrid Teas planted out early in the spring, gives one pleasure all summer. They are easily cared for, if the instructions given in this work are carried out. For those who possess small grounds and have but little time to attend to them we have that poor man's blessing, the Rosa rugosa, and its hybrids. This Japanese rose does not know how to "catch cold," and will stay longer with you and give far more pleasure than any poor relation. It blooms profusely in June and scatteringly all through summer, ripening its bright red, cherry-like berries during the late summer months. Its foliage is unusually fine and insect-proof. This feature alone should be highly appreciated, for the beauty of foliage is more than half the beauty of any plant. This rose was known to rosarians as early as 1845 , but its beauty and hardiness 
and its value in hybridizing were not appreciated until some forty years afterward, when Mr. Robert C. S. Carman, of New Jersey, and M. Georges Bruant of Poitiers, France, gave us the hybrids, Agnes Emily Carman, and Mme. Georges Bruant. While the former was produced first, thus giving the honor of producing the first Rugosa hybrid to an American, it was delayed in its propagation, and the French rose was the first on the market. In all of Mr. Carman's experiments the Rugosa rose was the mother plant, and it is a singular fact that the Agnes Emily Carman rose, bearing flowers having the color and scent of the General Jacqueminot rose, should have Harison's Yellow as the male parent. The success of these hybridizers caused others to enter the field, and we now have a host of good forms, all hardy and reliable. Where these hybrids possess some Tea blood, unusually cold winters may kill them back somewhat. The handsome Rugosa hybrid, Conrad F. Meyer, is sometimes "cut back" in winter. This type and its hybrids are splendidly adapted for forming entire hedges or large groups, and may be depended upon for flower and foliage.

The well-known dwarf rose, Hermosa, and the writer made their first appearance before the public at about the same time, and the former has graced our gardens for seventy-frve years. It is reliable and hardy with but little protection, and is one of the best bedders today. The same may be said of the Clothilde Soupert, one of the Iargest-flowered forms of the Polyantha class, introduced in 1884. In r880, Veuve Ducher introduced the charming dwarf Polyantha, MIle. Cecile Brunner, the queen of the so-called Fairy rose class, hardy with slight protection, and admirable for corsage bouquets. Its miniature buds, so delightfully tinted, are admired by all, especially by the gentler sex.

Who has not admired the Cherokee rose of the southern states, an escaped exotic, being the Chinese Rosa sinica, that has taken so kindly to the conditions offered as to thrive there on the waysides and fence corners? We of the North can have its counterpart, all except its evergreen foliage, in the extremely hardy Rosa spinosissima var. Altaica, 
from the Altai Mountains in Siberia. When in bloom, it is a charming sight in the purity of its single, pure white flowers. I cannot understand why this rose is scarce and hard to find, as in good soil it suckers rapidly and thus an increased stock is easily obtained.

The old-fashioned Sweetbriar, with its heaven-born perfume, often winter-kills here, but I grow it in among some tall-growing barberries through whose branches the Briar thrusts its long canes. The barberry shades the Briar canes in winter and but little loss occurs.

I tried Lord Penzance hybrids and, much to my regret, could not carry them over winter, so the charming Lady Penzance was banished from "Egandale."

The Persian Yellow and Harison's Yellow, as well as all the Mosses, are hardy here.

AII of the Baby Ramblers do well here, slightly protected, and are well fitted for borders of Iarge rose-beds. Ennchen Müller is splendid; as a cut-flower, each well-grown truss is a bouquet in itself; and, the flowers being loosely arranged, give an airy elegance to the decoration. The color is good in daylight or electric,- - desirable quality in any flower.

Hybrid Perpetuals and those grown as such require winterprotection. Some stand this covered-up condition better than others. Here is a list I gave in Bailey's "Cyclopedia of American Horticulture" some years ago, and I would not change it now. Undoubtedly, there are many more that will do as well if tried, but there are enough listed to create a garden for anyone.

The winter of I898-r899 was the most severe in this section I ever experienced, and many trees and shrubs, considered "iron-clad," were killed. The following is a list of roses which wintered here under protection and which came out in good condition:

Captain Christy Captain Hayward

Garden Favorite

General Jacqueminot

John Hopper

La Rosiere
Louis Van Houtte

Magna Charta

Mrs. Paul

Mrs. R. G. Sharman-Crawford

Paul Neyron

Prince Camille de Rohan 


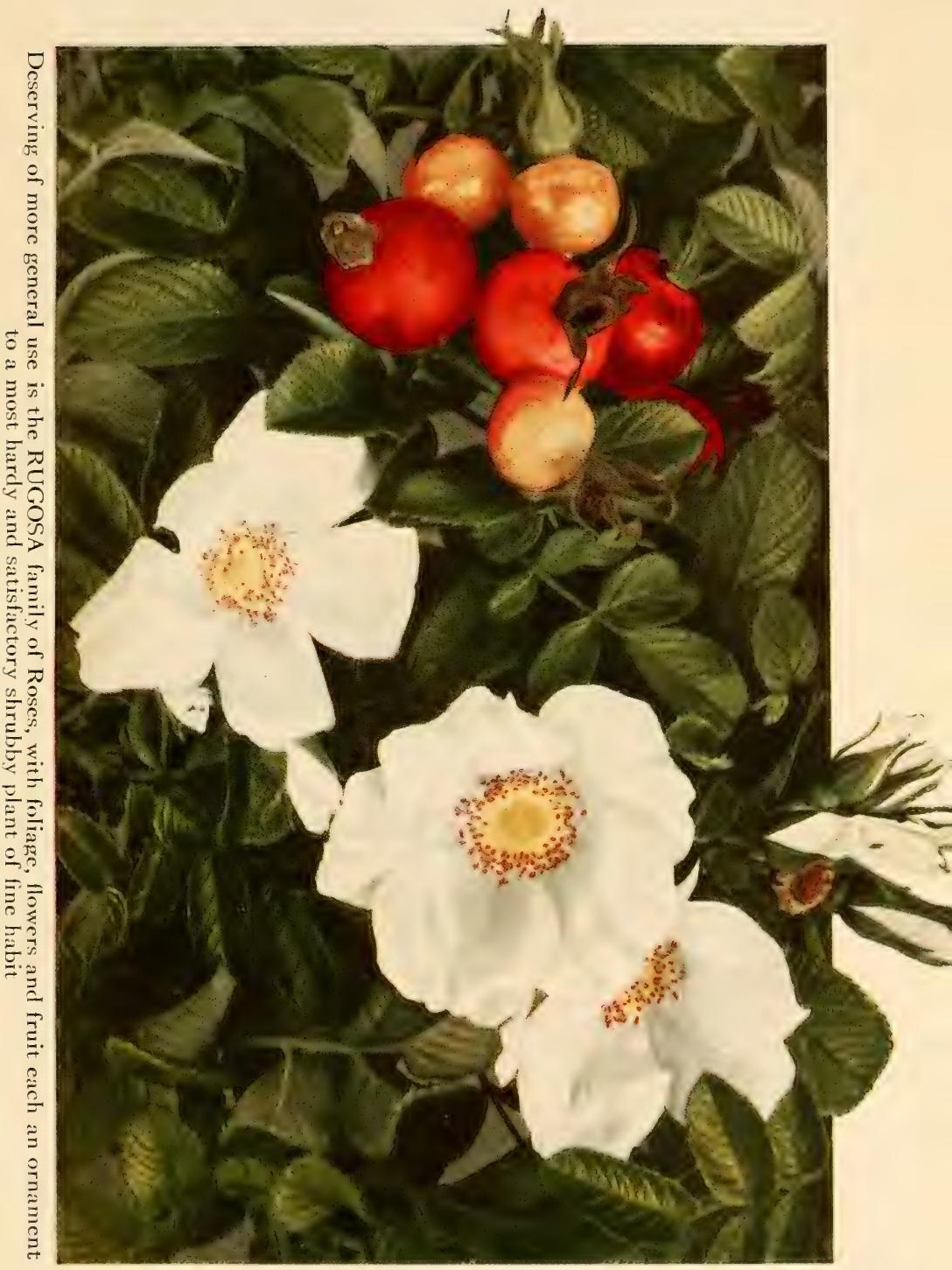


The following eleven were in fair condition and recovered their form during the season:

Alfred Colomb

Anna de Diesbach

Baronne Provost

Countess of Oxford

Eugene Furst

Lyonnaise
Mme. Gabriel Luizet

Mme. Victor Verdier

Pierre Notting

Prince of Wales

UIrich Brunner

This section, together with many in the northern states, suffered for the want of a suitable number of climbing roses that might be carried over the winter with an easily prepared protection, until the advent of the Crimson Rambler, which reached England from Japan in I 878. This was followed soon after by Rosa Wichuraiana and its hybrids. Up to this time we had to be content with Queen of the Prairie, Baltimore Belle, Russell's Cottage, and Multiflora rose Greville, or Seven Sisters. The first two were produced by Feast of Baltimore in 1843 by hybridizing that most excellent hardy Prairie rose, $R$. setigera, with some of the garden forms of the day. I have often wondered why hybridizers had not used this hardy semi-climbing rose more frequently in their work. About all the climbing roses, bearing a large percentage of Rugosa or Wichuraiana blood, are hardy with a slight protection in winter. Which is the best is merely a matter of choice.

The new, prostrate rose, Max Graf, may be used as a climber and is hardy without protection. Grown without support, it lies close to the surface, thus making a splendid ground-cover. In beds, well established, the new canes will rise up some 18 inches and then, arching over, rest their tips upon the ground. Planted at the top of a wall they hang over like a veil. The bright green foliage indicates a mixture of the Rugosa and Wichuraiana blood and is attractive all summer and fall. Free from mildew or insect pests. In its blooming season, June and July, it is covered with a clear pink flower similar in color, size and substance to the pink Rugosa. 
Editor's Note.-Mr. Egan has also made careful test of the leading Hybrid. Teas, both for their blooming qualities and also for hardiness and suitability for his climate. He plarited three plants each, did not disbud, and the second summer out, which was a hot and trying one, he cut as shown in this report:

NAME OF VARIETY

I. Ecarlate . . . . . . . . $43^{\mathrm{T} / 3}$

2. Killarney . . . . . . . 27

3. La Tosca. . . . . 262/3

4. Grossherzog Friedrich . . . . . $192 / 3$

5. Radiance. . . . . . . 26

6. Lady Ashtown (two plants) . . . . I7

7. Ophelia . . . . . . . $16^{1} / 3$

8. Majestic . . . . . . . . . . . 18

9. Mrs. A. R. WaddeII . . . . . . I6

Io. Mrs. Aaron Ward . . . . . . . I4

i i. Lady Ursula . . . . . . . . $18^{1 / 3}$

12. Duchess of Wellington . . . . 8

13. Florence Pemberton . . . . . $102 / 3$

I4. Pharisäer. . . . . . . . . $15^{1 / 3}$

15. Viscountess Folkestone. . . . . I3

16. Souv. de Gustave Prat . . . . . . 1 I0 $2 / 3^{3}$

17. Mme. Caroline Testout . . . . $142 \frac{2}{3}$

18. Lady Alice Stanley . . . . . . . $131 / 3$

19. Mme. Leon Pain . . . . . . . . $9^{1 / 3}$

20. Prince de Bulgarie. . . . . . . 12

21. Gustav Grunerwald . . . . . . 9

22. General MacArthur . . . . . $81 / 3$

23. Lieutenant Chauré … . . $10^{2} / 3$

24. Willowmere . . . . . . . $142 \frac{2}{3}$

25. Lady Pirrie . . . . . . . I0

26. Duchess of Westminster . . . . $10 \mathrm{I} / 3$

27. Laurent Carle . . . . . . . $82 / 3$

28. Mme. Ravary . . . . . . . . . $81 / 3$

29. Farbenkönigin . . . . . . . I0

30. Antoine Rivoire . . . . . . . . . 12

3I. Dean Hole (first year) . . . . . . 4

32. Mme. Jules Bouché . . . . . . $62 / 3$

33. Earl of Warwick . . . . . 7

34. Mme. Melanie Soupert. . . . 9

35. Mrs. Wakefield Christie-Miller .

36. Mrs. F. W. Vanderbilt

37. Jonkheer J. L. Mock (buds come bull-headed)

38. Mme. Jenny Gillemot .

39. Chateau de Clos Vougeot (weak grower) . . . . .

40. Mme. Edmond Rostand

4I. Mrs: George Shawyer
42. Louise C. Breslau . .

Av. blooms Av. blooms
after per plant for Aug. I whole season

\section{5}

$25 \frac{2}{3}$

$18 \mathrm{I} / 3$

25

I6

$17 \mathrm{I} / 2$

I $8 \mathrm{I} / 3$

I 5

$15 \frac{2}{3}$

$\mathrm{I} 7 \mathrm{I} / 3$

12

$22 \mathrm{I} / 3$

I $91 / 3$

I3

I $3 \mathrm{I} / 3$

I5

IO

IO $1 / 3$

I4

I I $1 / 3$

$\mathrm{I}_{4}$

I $32 / 3$

I I

7

$\mathrm{IO}^{\mathrm{I} / 3}$

$9^{I / 3}$

$\mathrm{IO}^{2} / 3$

$12 \frac{2}{3}$

$\frac{9}{6}$

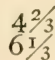

6

$52 / 3$

4

7
$9^{2 / 3}$

$71 / 3$

$42 / 3$

$9^{2} / 3$

$82 / 3$

$5^{2 / 3}$

5
$72 / 3$

$8 \mathrm{x} / 3$

$61 / 3$

II $8 \mathrm{I} / 3$

$52 \frac{2}{3}$

45

$442 / 3$

42

$341 / 2$

$34^{2} / 3$

33

$3 I^{2} / 3$

$31 \frac{1}{3}$

$301 / 3$

$301 / 3$

30

$281 / 3$

$261 / 3$

$252 / 3$

$242 / 3$

$23^{2} / 3$

$231 / 3$

$231 / 3$

23

22

$2 I^{2} / 3$

$2 I^{2} / 3$

$201 / 3$

$192 / 3$

I9 $1 / 3$

18

$171 / 3$

$162 / 3$

$162 / 3$

$161 / 3$

$152 / 3$

$142 / 3$

14

I 323

I3

$12 \frac{2}{3}$

$52 / 3 \quad$ II $2 / 3$

$5 \mathrm{~T} / 3$ II

$62 / 3$ I0 $2 / 3$

92/3 




In Elizabeth Park Ruse-garden, Hartford, Connecticut 


\section{The Increasing Regard for Roses}

In his book, "The Cultivated Man," Charles W. Eliot says: "A brook, a hedge-row, or a garden is an inexhaustible teacher of wonder, reverence, and love."

Another one of "America's noblemen," G. A. Parker*, with exquisite feeling, thus portrays the possible influence of the rose on the lives of men, when, in telling of the rosegarden at Elizabeth Park, he says:

"I have come to think of beauty as the love-letter of the Creator, through which $\mathrm{He}$ is wooing us unto Himself; for beauty is spiritual, and not physical.

"A love-letter is a message into which the sender puts a part of his very self, and the one who receives it, in some mysterious way, weaves it into a part of his very life. It matters little what words are used or how the message is sent, providing it becomes a part of the sender and of the. receiver. Surely the Creator uses a most beautiful form when He avails Himself of the roses to convey His message."

Among the real rose-lovers now scattered widely over our great country, it is difficult to conceive of a finer loyalty than already exists toward the flower of their choice. Such devotion as theirs is bearing fruit. Better roses in their gardens are arousing more abundant admiration on the part of neighbors. This results in more "recruits." Rose societies spring up here and there. The members help each other, and more and more each one comes to know the joy of growing one's own roses. This is just what has been going on in many sections of our great country. The delights of rose-growing have been revealed to vastly increasing numbers of amateurs within the past few years. The "garden magazines" have helped. The "garden clubs" have been a prominent factor.

There are, perhaps, half a dozen rose men lecturingt on this fascinating subject and forwarding the good work. All have helped, and the combined efforts of these various agencies are beginning to bloom into activities of great promise.

\footnotetext{
*“American Rose Annual," 1916, pages 71, 72.

$\dagger$ A list of these will be furnished on request.
} 


\section{The American Rose Society}

aims "To increase the general interest in the cultivation and improve the standard of excellence of the rose for all people."

Whether you grow one rose or acres of them (whether you are an amateur or professional), you will find it delightfully profitable to belong to the American Rose Society. Already nearly 2,00o folks seem to have found it so, and are - sending in the names of their friends from every part of our great country.

The highest ambition of the American Rose Society is to serve its members. This it strives earnestly to do.

It stimulates and fosters the holding of exhibitions in every available rose center, and heightens the interest by awarding-Gold, Silver, and Bronze Medals, or Certificates of Merit for prize exhibits.

It holds annually one or more rose exhibitions, usually in connection with some Iarge flower-show.

Tickets for such shows are sent free to all members.

Local societies are organized, in affiliation with the parent body, with consequent advantages to associate members.

A complete file of available roses and registry of new ones of merit is constantly maintained, preparatory to the publication of an official catalogue in the near future.

Important rose test-gardens are established at Hartford, Conn.; Washington, D.C.; Ithaca, N. Y.; Minneapolis, Minn.; and Portland, Ore.

Results obtained in each separate climatic zone are thus available for the enlightenment of members.

The American Rose Society also publishes the American Rose Annual. It is ably edited by J. Horace McFarland, of Harrisburg, $\mathrm{Pa}$., and is available to members only. It contains, each year, a comprehensive record of rose progress in America, with original, helpful, up-to-date information. It is beautifully illustrated in color and sepia, and contains about I 80 pages.- Membership is annual, at $\$ 2$, and life, at $\$ 50$.

For further information or enrollment, address Editor, "How to Grow Roses," West Grove, Pa. 


\section{Fragrant Roses}

\section{By Dr. W. VAN FLEET}

"Agreeable fragrance is one of the most valued attributes of the perfect rose, though many indispensable species and varieties do not possess it in marked degree, and not a few are either odorless or even distasteful to the sense of smell. . .

"The wild roses of North Europe mostly have faint fragrance or are scentless and the same may be said of our Middle West and Pacific Coast species, though there are a few exceptions in the extreme Northwest. . . .

"True rose-fragrance arises from the presence of rose-oil or attar, a volatile oil elaborated in the petals of the blooms just before opening. It appears most abundantly in the cells near the base of the petals, yet is present in such small quantities that it usually requires a ton and a half of fresh plucked rose petals to produce a pound of oil which resembles brownish butter.

"Roses of the hardy, free-flowering Rugosa type from Japan, which grow weIl in America, typify rose-perfume in its most pleasing form. Some of the hybrid Rugosas are also very fragrant, while others, although fragrant, have not the intense fragrance of the single-flowered Rosa rugosa rubra (red) and $R$. rugosa alba (white).

"Attar of roses is secured from the fresh petals of fragrant roses by the ordinary process of distillation and condensation used to recover all essential or volatile oils produced in nature It exists in such small quantity, however, even in the best perfume varieties, that it remains in solution in the water of condensation that comes over from the still and must be washed out or redistilled several times before it may be skimmed off, as with more abundant oils. These first waters, however, are most deliciously scented, and, in this country at least, would be more valuable as true commercial rose-waters than the attar itself when extracted from them.

"There is one remaining entrancing rose-odor-the despair of perfumery chemists - that of the Sweetbrier foliage after a rain. It cannot be recovered by any known process and lives and dies with the occasion during which it is perceived. . . .

"Rose aromas are not congenial to all persons, and occasionally an individual is found to whom they are annoying, and even hurtful, in the way of causing catarrhal symptoms; but to the overwhelming majority of gardeners, fragrance is a prime requisite for the thorough enjoyment of a rose bloom."

ELITOR's Note. - As a sample of the character of the r919 "American Rose Annual," these extracts from pages $14^{-19}$ are published here by permission of the Editor, J. Horace McFarland, Harrisburg, Pa. 


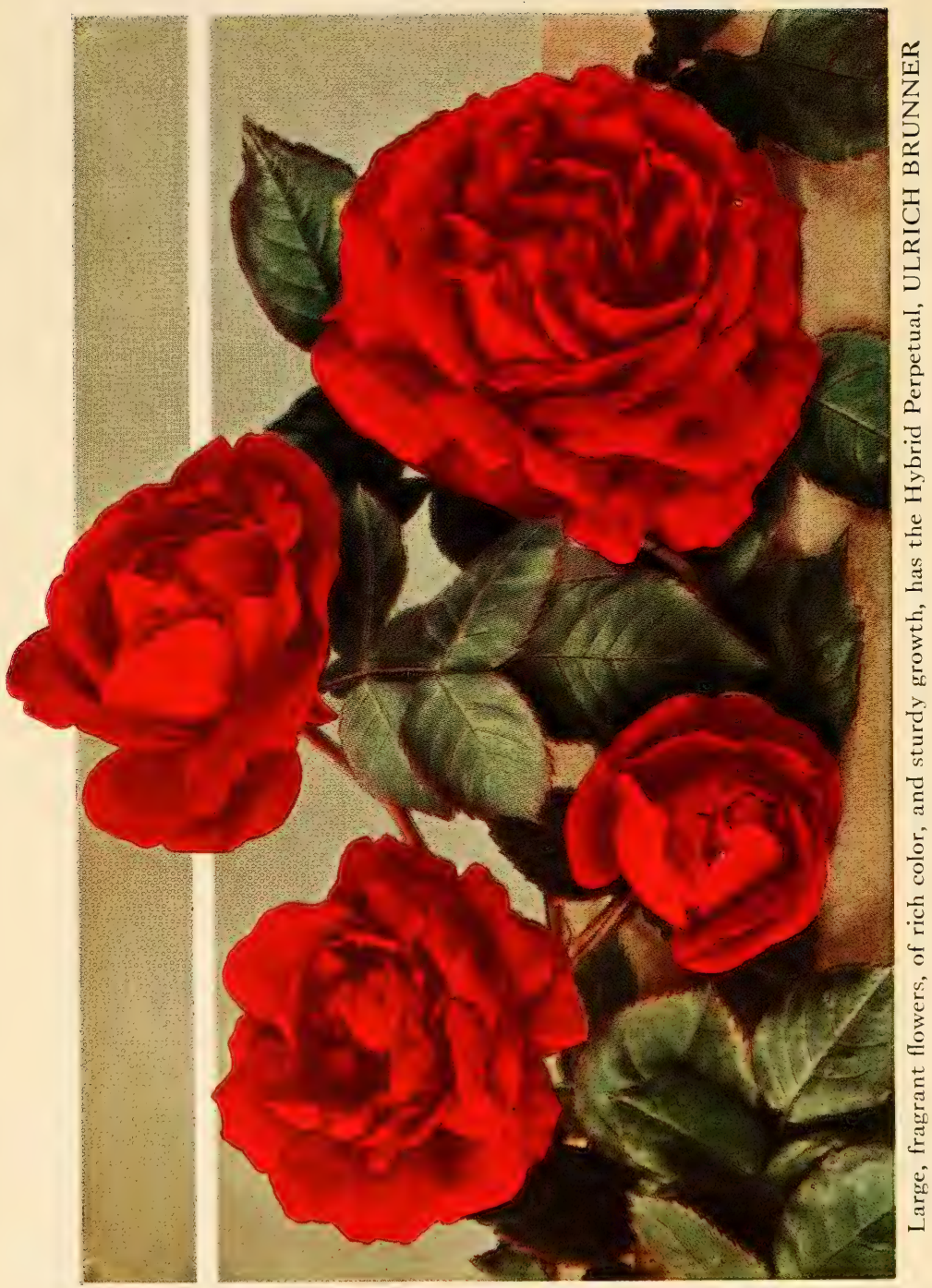




\section{Municipal Rose-Gardens}

Hartford, Connecticut, was the pioneer for America; and she builded weII. Starting in 1904, in Elizabeth Park, there were laid out one and one-quarter acres. This the author visited first upon his return from a tour among the more prominent rose-gardens in England, Ireland, Holland, Germany, and France. While delighted with the cultural success and magnificent show of varieties, there seemed in the ensemble much to be desired in the matter of treatment and arrangement. This will probably be true of most of the testgardens referred to in the above section, because beauty of landscape effect is not the first thing sought for in a rosegarden made primarily for test purposes, although the more there is of grace and beauty, of charm and enchantment, by reason of the arrangement, of course, the better it is.

But Hartford led the way, and nobly continues to render this nation, at least the northeastern part of it, a great service. She showed that even a little public rose-garden, well done, begets enthusiastic public appreciation. Mr. G. A. Parker, Superintendent of Parks, of Hartford, reports I 6,000 people having visited this rose-garden in one year. There are in it three hundred different varieties of roses and about fifteen hundred separate plants, and the cost, both for construction and maintenance, in eleven years has been \$0.0I73 per visitor. But as for its influence upon, and value to, the people who have come to see it, no money estimates can be made. If any reader feels inclined to doubt this last statement, permit us to suggest that he submit his feelings to the test of a visit.

There are many American cities which have roses in their parks, and these cities are extending their plantings; but as yet only a limited number have definitely set apart, and regularly arranged for, a real rose-garden.

If any of our readers have the opportunity to visit PortIand, Oregon, certainly one of the sights of that city of wonderful promise is the municipal rose-garden. It is larger, perhaps, than that of Hartford, - a sunken garden with rose- 


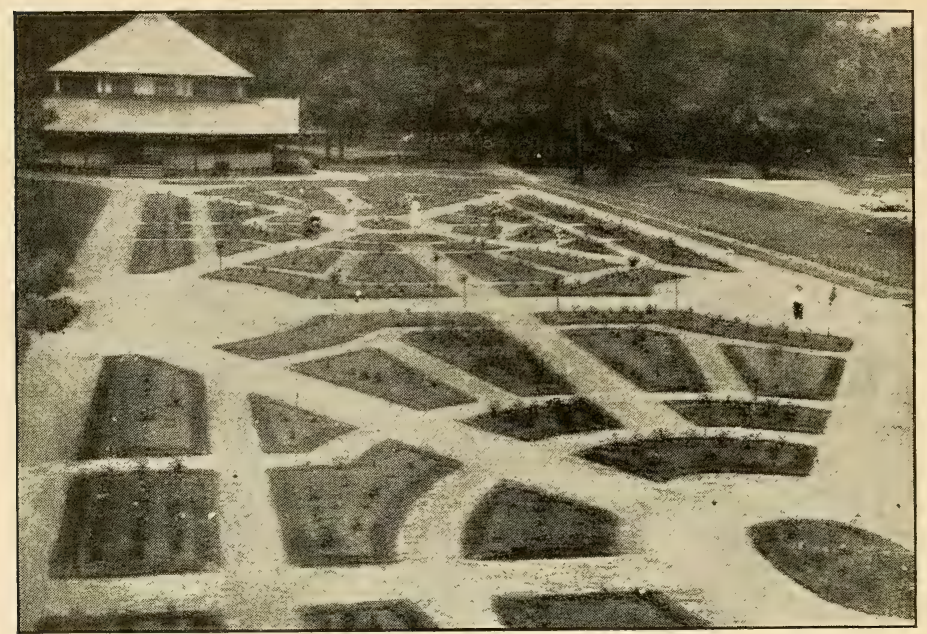

Municipal Rose-garden, Cleveland, Ohio. One year old

covered terraces; a fountain-centered system of walks and a large amount of growth; and, as nearly every rose-lover knows, a gratifyingly long season of bloom. It is, we believe, true of Portland, as of no other city, that the commercial men have long realized the value of the rose and its exploitation as an indirect, though very definite means of spreading, world-wide, the fame of that rose-favored corner of the earth. This is a reason why there is enthusiasm in Portland back of the conception to establish in another part of the city another municipal rose-garden that shall outclass any other in America. And why should Portland not do so? The author would enjoy telling his readers much more about the magnificent hedges of roses in Portland; of the great annual rosefestivals, with electrical displays; of many different parades; of automobiles; of the Royal Rosarians and their Queen of the Roses with her attendants,-all doing homage to the rose.

In I9I5, at Cleveland, Ohio, for the first time there appeared on display a most creditable municipal rose-garden, its success being due in large measure, doubtless, to the able hand of their superintendent of parks. No climbing 
roses surrounded it when the author enjoyed its rich June bloom, but the varieties had been well chosen for that locality, and arranged in good taste. AII were bush roses and were grouped in beds, with an arrangement of walks making the annually recurring display easily accessible to large numbers of people. Time and growth, with the good care it is sure to get, will furnish the softening and enriching effect that only age can supply. It is a splendid beginning, and such as one would expect of Cleveland.

And so, in sequence, might be mentioned a few other cities whose activities along this line have come to the attention of the author.

Syracuse, N. Y., has now the beginning of a most creditable municipal rose-garden, the result of a demand made by the citizens, promoted by an energetic rose society and its indefatigable president, Rev. E. M. Mills, D.D. Long life to him!

Now, too, we are happy to report the establishment of a real rose-garden in the Bronx Park system of New York City. The New York Horticultural Society and affiliated organizations have carried out creditably a rose-planting that promises to rejoice the hearts of countless thousands of people. Let us all hope that it may prove easily accessible to those who most need the inspiration and pleasure which such a garden is so well calculated to furnish.

And now for the Brooklyn Rose-Garden, the plans are weIl under way, and excellent progress is being made.

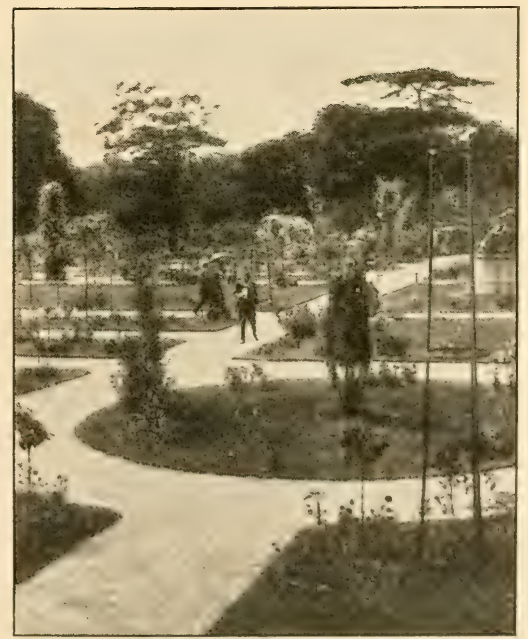

View in the Bagatelle Municipal Rose-Garden, Paris 


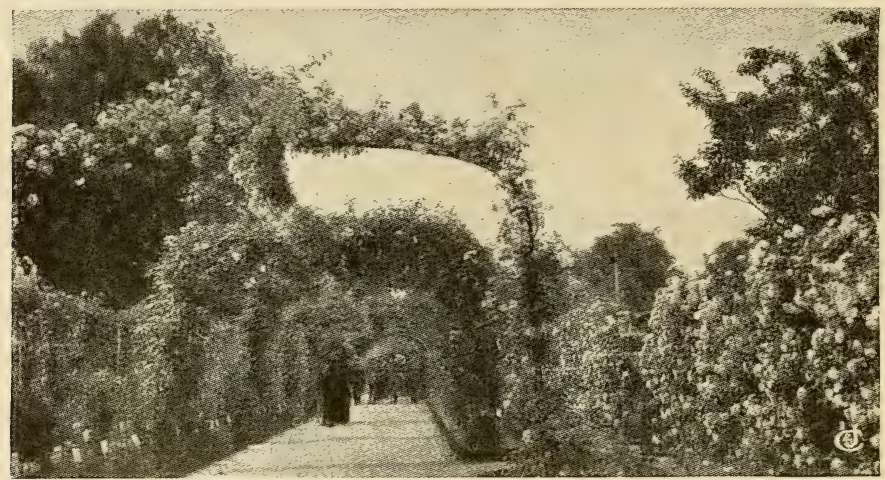

Roses, roses everywhere

\section{A Famous Rose-Garden}

The most beautiful rose-garden I have yet found in either America or Europe was near Paris. Accompanied by Mrs. Pyle, I arrived at the Roseraie de L'Hay early one day, and we lingered there till sunset, enchanted. A permanent rose-garden with thousands

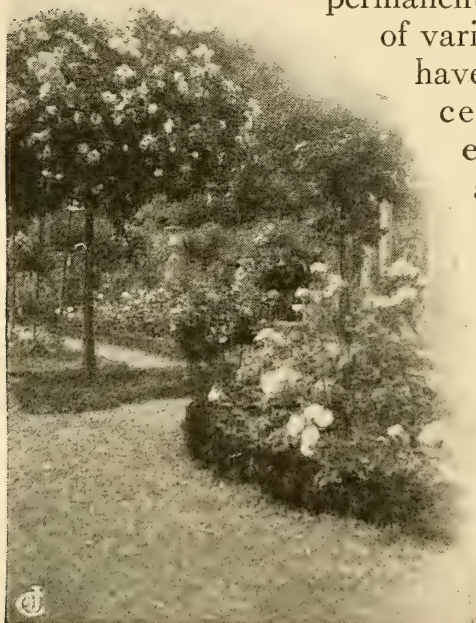

Note this giant Tree rose varieties, it includes roses said to ave originated in the sixth century B.C. Roses from every continent are arranged and trained in all imaginable styles, from borders of Baby Ramblers to giant Tree roses, I5 feet high and Io feet spread. Tunnels completely covered with climbing roses form outlooks through the garden, with here a bit of statuary, there a fountain flashing in the sunshine, with roses, roses everywhere, from the broad- 


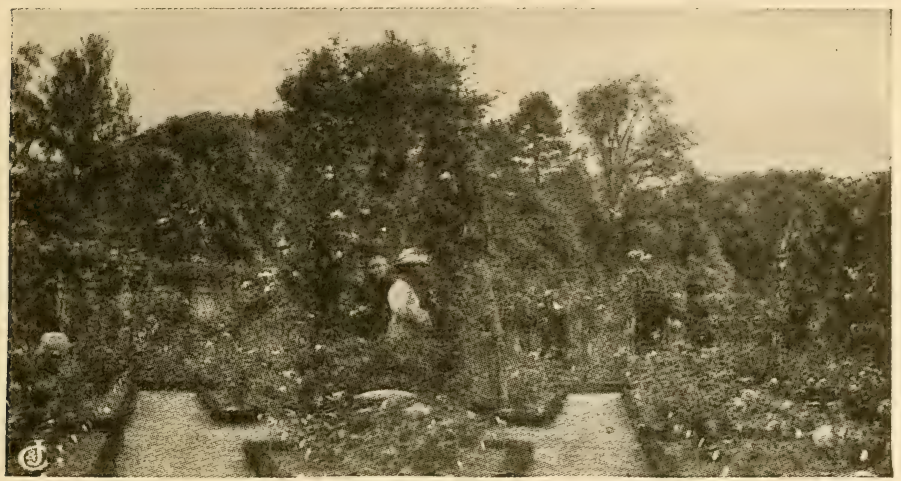

And here we lingered till sunset

petaled, deep red Lion climber to the splendid M. Gravereaux, named in honor of the owner of this magnificent garden. We strolled down the long, box-bordered pathways, with familiar faces among the roses looking up at us frombeds at our feet, and climbers looking straight at us, and half-beckoning from either side, as we passed, until, spellbound, we stood and gazed down the long vista of colorcovered beds, back-bordered with still other climbers in bloom. And this is only one picture out of hundreds of such! What a love for the rose must have helped to fashion the quiet arbors and festooned balustrades, the archway entrances, artistic screens, and disappearing pathways, so well planned that every turn brought a fresh surprise, each one more entrancing than the other!

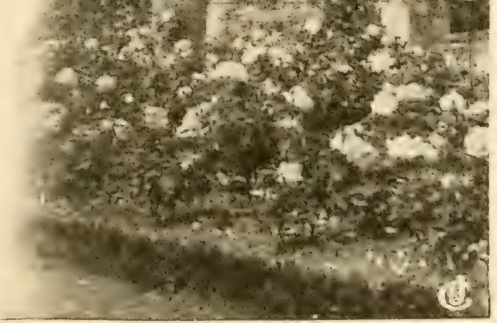

The Temple of Love 
Finally, so well hidden by an encircling temple of trees that we nearly missed it, was an open-air theater with turf seats, and along the front of the stage, for footlights, was a brilliant row of blooming roses. There, amid this paradise, in charming French fashion, our host entertained his guests with a musical recital. From this garden came the inspiration for starting the Municipal Rose-Garden of Paris in the Bagatelle. Now that Mons. Jules Gravereaux is gone, we realize what a happy memorial it is that his native city should maintain for all time, we hope, this great rose-garden, which he started for the pleasure of his fellow citizens.

[From notes and photographs taken by Robert Pyle, president of The Conard \& Jones Co., West Grove, Pa., on the occasion when he represented the American Rose Society and acted as a judge at the International Contest of Garden Roses at Bagatelle, Paris, June, I9I I.]

\section{The Red Rose Church at Manheim}

We know of no more unique ceremony in America than Manheim's "Feast of Roses." In I750, Baron Heinrich Wilhelm Stiegel, coming from Germany, settled in Lancaster County, Pennsylvania, and founded the little town of Manheim. He prospered in business and later deeded to the Lutheran congregation (which he organized in 1769) a plot of ground for the erection of a house of worship with the following stipulation: "yielding and paying therefor at the said town of Manbeim, in the month of June, yearly forever after, the rent of ONE RED ROSE, if the same shall be lawfully demanded."

And now each year, with appropriate exercises, the congregation of the Manheim Lutheran Church pays to the heirs of Baron Stiegel the unique ground-rent of "one red rose," and each year recalls the memory of a man who, though "dying in poverty, had yet left the noblest of all memorials, the Iove, reverence, and gratitude of a community whose industry he had stimulated, whose ideals he had fostered, for whose spiritual welfare he had made permanent provision." (PubIished with the permission of the pastor, Rev. A. E. Cooper.) 


\section{Rose-Beads}

For the following formula the author is indebted to a good friend of his from New York State, whose experience in making rose-beads is far more extensive than his own.

"Gather the petals of roses-even newly fallen ones will do-till you have, say, half a peck. Grind these through a meat-chopper till they become pulp. In order to have the beads jet-black when finished, place this pulp in an iron pan, or, lacking that, mix in a teaspoonful of ground copperas (ferri sulphas), and stir thoroughly; the mixture will soon become brown. Set it now in the sun or a warm oven till it gets black. After this, put all through the meat-chopper again till it becomes like putty, and then form the beads. They can be made any shape you like,-round, square, hexagonal, etc.,but form them twice the size you wish to have them when finished. Rolling them into little balls with the hand will make smooth beads. If you wish them frgured, the buttend of a steel writing-pen is a convenient tool, to be used, of course, when the beads are still soft. When properly formed, transfix them to a board with a pin, then keep them hot and dry, and in two or three days they will become small and hard, and may be strung through the hole left when the pin is removed."

A European authority gives us a slightly different formula, and recommends using a mortar instead of the more prosaic and modern meat-chopper.

"Freshly gathered rose-petals are beaten into a pulp and then dried, but before becoming completely dry, rose-water is added and they are again beaten and dried, the operation being repeated till the pulp has become very smooth. Then the desired shape is given and they are perforated in order to thread them, and so a kind of bead is formed, which is dried. When they have become very hard, they are smoothed and polished, after which they are rubbed with oil-of-roses in order to give them more perfume and gloss. If a brass mortar be used, the pulp takes a deep black color, through the action on the metal of the gallic acid contained in the roses. On 
the other hand, if a marble mortar be used, blue and red and other colored beads can be manufactured according to the coloring materials employed. The black beads are most highly prized. They have been manufactured principally at Adrianople, Smyrna, and Constantinople."

\section{Attar of Roses}

The reader will notice on another page a short account of a visit made to that most beautiful rose-garden south of Paris, the Roseraie de L'Hay. Many chapters might be written of this little paradise about which clusters so much of interest to a rose-lover. But there is in that wonderful garden a quaint thatched "summer-house," as we in America might call it, rose-embowered. On the occasion of the author's visit, there was at work in the little cottage a white-aproned chemist with large-sized retort, test-tubes, spirit-lamps, and other appliances. The rose-petals which had been gathered in the garden were being reduced to essence or attar of roses. M. Gravereaux has improved the method of extracting the oils, and, furthermore, has proved by extensive experiments that certain perpetual-flowering roses, like Mme. Caroline Testout, and others, are capable of producing a much larger amount of the essence than the Damask and Centifolia roses heretofore largely used.

The method employed by M. Gravereaux is superior to that of the Bulgarians, Persians, and Algerians, whose apparatus is most primitive, as the following will indicate: The rose-petals must be distilled as they are picked, otherwise much of their odor will be lost. They are brought right to the stills, which are made of copper, and there mixed with only water, the quality of which is said considerably to influence the essence distilled. After having twice boiled down the mixture to one-eighth or one-tenth its original volume, it is allowed to cool, and is set in open bowls at a constant temperature. Gradually the essence rises and swims on the surface in yellowish patches, which are skimmed off with a mother-of-pearl spoon. This operation, usually falling upon 


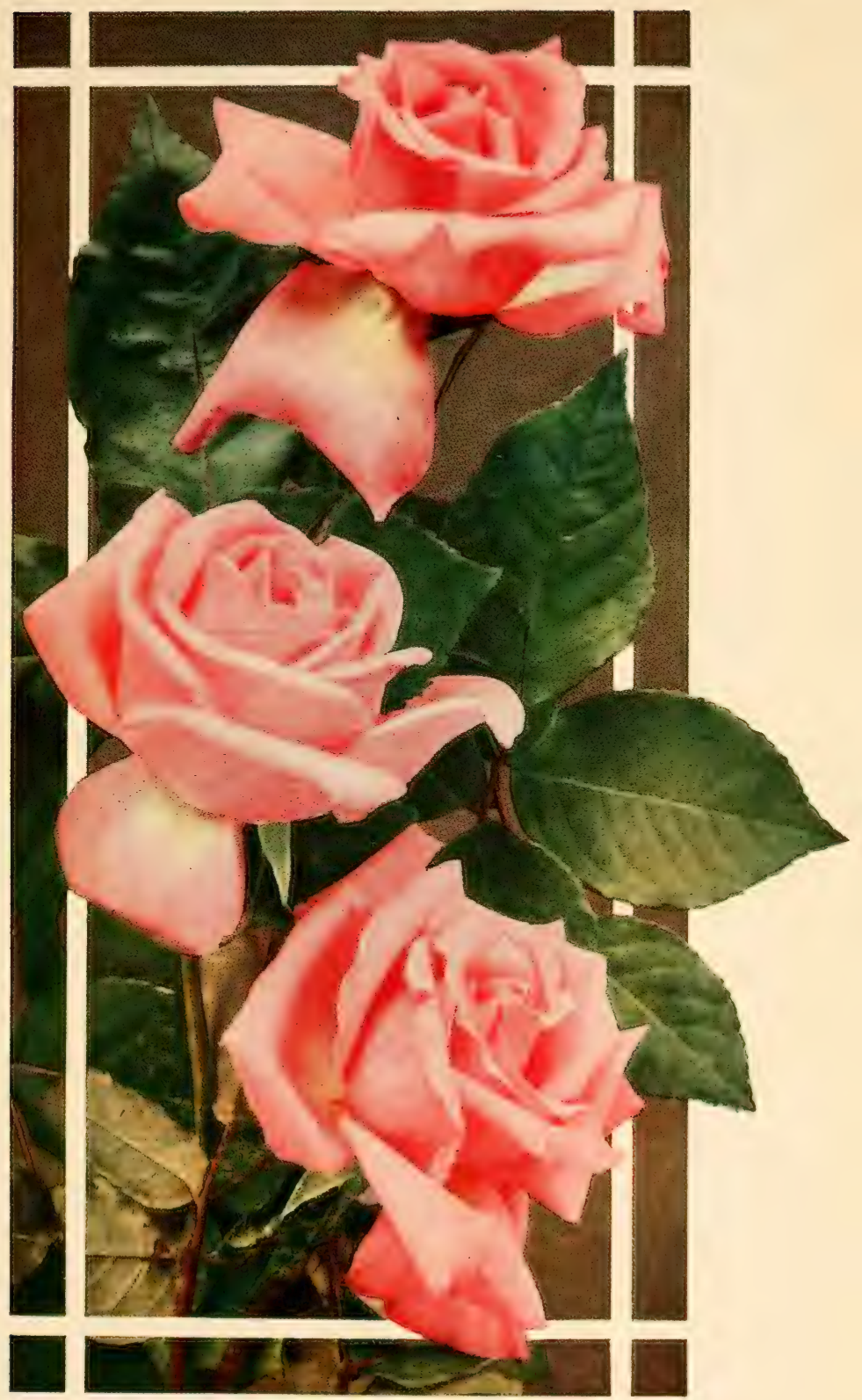

BRIDESMAID is most appropriately named, suggestive of what is best among the prettiest pink Tea Roses 
the eldest member of the family, is carried out with a solemnity befitting its importance. What this must mean to the peasants is better understood when we realize how feather-light rose-petals are, and that I 50 pounds $(2,400$ ounces) of them ordinarily yield less than one ounce of the essence of the rose.

It is not to be marveled at, therefore, that it is expensive, not alone for the above reason, but also because of its importance in the fabrication of the finest perfumes. It has, furthermore, the valuable quality of increasing and fixing other perfumes, just as the rose itself has the quality of developing in those who work with it qualities of fine moral character.

\section{Hybridizing}

This book attempts in no way to cover the subject of hybridizing, save to refer to some sources of information regarding a work that calls for long-sustained attention, and almost limitless patience, with no assurance as to results. Amateurs, as well as professional rose-growers, have made valuable contributions to our lists of roses, and certainly the future must offer more adequate recompense to the successful breeder of roses than has been the case in the past.

Rev. Joseph H. Pemberton*, for the beginner, gives directions that appear to be easily followed by one who has the time and facilities to undertake the work.

Every hybridizer will be interested also in the articles by Dr. White and Dr. Van Fleet in "The American Rose Annual" for I9r6; also in the "Stammbuch der Edelrosen," by Dr. G. Kruger. The edition of this work, published in 1906, at Trier, Germany, contains a most complete listing of the hybridized roses in commerce, including parentage, hybridizer, and date of issue. For example, under Mme. Caroline Testout, are given fifty-eight immediate descendants, showing also the name of the other parent in all except nine cases. It would seem to be an invaluable work for anyone who wishes to undertake hybridizing.

*“"Roses," page 229 (see Bibliography). 


\section{Bibliography}

Beginning with "The Rose Manual," by Robert Buist, in I 884, there have been issued in America at least eighteen different works, the most noteworthy of which we list below:

The Rose. By H. B. Ellwanger. 1882. 293 pp. Dodd, Mead \& Co., New York. This was Iong the standard rose book.

A Book about Roses. By S. Reynolds Hole. i 883.326 pp. Wm. S. Gottsberger, New York. An American reprint of a standard English work. Highly entertaining work on roses, and most inspiring.

Roses and How to Grow Them. Collected magazine articles. Igio. 199 pp. Doubleday, Page \& Co., Garden City, N. Y.

Commercial Rose-Culture. By Eber Holmes. igi i. I6s pp. A. T. de la Mare Printing and Publishing Company, New York.

Everblooming Roses for the Outdoor Garden. By Georgia T. Drennan. I9I2. 262 pp. Duffreld \& Co., New York.

The Practical Book of Outdoor Rose-Growing. By George C. Thomas, Jr. I9I4. I 56 pp. and 96 plates in color, etc. J. B. Lippincott Company.

The American Rose Annual. i9i6, i917, i9i8, i9i9, 1920. Published by the J. Horace McFarland Company, Harrisburg, Pa., for The American Rose Society. Contributions upon roses, rose-growing and rose-gardens. Recounts the year's activities. Free to members only.

The following are all edited from the English standpoint:

Roses: Their History, Development, and Cultivation. By Rev. Joseph H. Pemberton, Vice-President of the National Rose Society. 1908. 336 pp. Longmans, Green \& Co., London and New York.

Roses and Rose-Growing. By Rose G. Kingsley. I908. I63 pp., 28 full-page color-plates. The Macmillan Company, New York and London. With special attention to the best roses in each of the various classes, regarded from the English viewpoint.

Roses for English Gardens. By Gertrude Jekyll and Edward Mawley. I902. I64 pp. George Newnes, Ltd., London. Although relating to English gardens, it is, nevertheless, most entertaining, and by its thoroughness helps to clear up many questions left unanswered by other authorities.

Rose-Growing Made Easy. By E. T. Cook. 200 pp. Another English publication, suggestive and helpful, and written apparently by one with long years of first-hand experience.

The Rose Book. A complete guide for amateur rose-growers by $\mathrm{H}$. H. Thomas. I9I3. $283 \mathrm{pp}$. Profusely illustrated. Treats well the various uses to which roses may be put.

The Book of the Rose. By Rev. A. Foster-Melliar, M.A. 352 pages, 33 illustrations. Macmillan \& Co. 1902. A comprehensive and inspiring authority covering well the entire subject, for the use of the amateur.

For a list of rose-books in all languages the "Cyclopedia of American Horticulture" refers us to the "Bibliografia de Ia Rosa," Vergara, Madrid, I892. 


\section{Synonymous Roses}

Some roses have acquired new names that seem to be an improvement; for example, Dutch Beauty in place of Veluwezoom. Another case is Mme. Norbert Levavasseur; when once planted and thoroughly domesticated, she answers to the name of Red Baby Rambler. But, if you wish to order Red Baby Rambler, remember there are nearly half a dozen roses so called; so, if you want to be certain, refer to the following list for guidance. Renaming a rose with intent to deceive has come to be regarded by rosarians as a crime. When a second name is adopted for the sake of euphony, the original name should be carried in parentheses.

Anna de Diesbach

Baby Dorothy, Pink

Baby Rambler, Pink

Baby Rambler, Red

Baby Rambler, White

Baby Rambler, Yellow

Baby Tausendschön

Baby Tausendschön

Ball of Snow .

Dorothy Dennison.

Dorothy Perkins

Dorothy Perkins, Red

Dutch Beauty

Green Rose

Killarney, Striped

Killarney, Orange

La France, Red

La France, Striped

La France, White

La Reine des Neige

Magnolia Rose

Maman Cochet, Yellow

Maman Levavasseur

Mignon

Mrs. W. H. Cutbush

Mrs. W. J. Grant

Prima Donna

Prince Camille de Rohan

Queen, Thé

Rambler, Golden

Rambler, Pink

Rambler, White

Rambler, Yellow

Sweetheart

Thousand Beauties

Virginia R. Coxe

White American Beauty

Wm. R. Smith

Wm. R. Smith

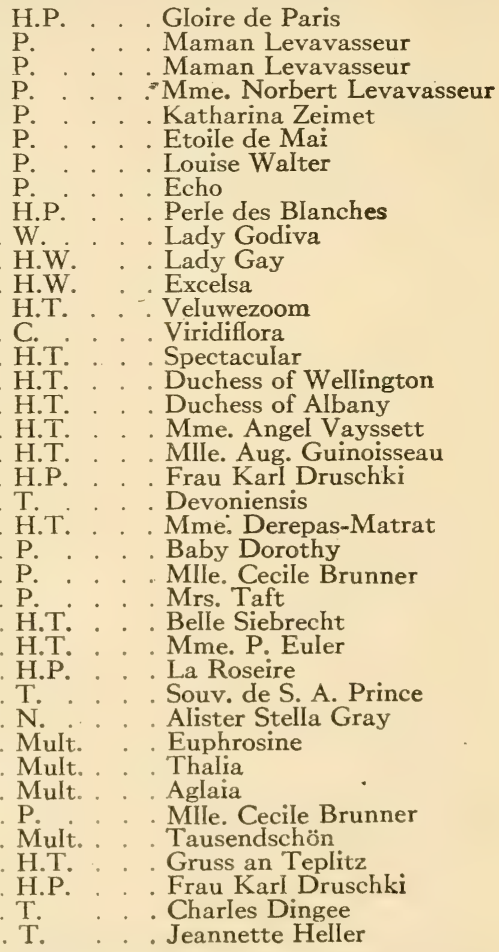

N.B.-See also common names to rose species, foot of page 107. 


\section{Analysis of Species}

It is doubtful if anyone will have come thus far in this little book, who is not, with the author, a real seeker after truth. Just as the story of man becomes doubly interesting as we trace back his development from the earlier types of man, so with the rose. A present-day Radiance or Rayon d'Or is a vastly more fascinating object of attention when one can go to another corner of the garden and point out to visitors the true progenitor of that race. Hybridizing deserves a complete chapter of its own. Right here let us study what bas been done by the guiding hand of man. Family charts are a useful aid in pointing out relationships. A diagram may be more illuminating than many pages of description. Therefore, as an introduction to the various best-known classes, pause a moment to survey* this analysis of species on the two following pages. This the author conceives to be a most helpful outline of the many, many families that make up this interesting race of flowers.

In this book there has not been room to describe the rose species. We would, however, call special attention to certain "types" which we have starred in the following list. Their place is not in a bed with the Teas or Hybrid Teas. Consider for example, Hugonis- that recent acquisition from China. In three seasons it will be 4 to 5 feet high and in bloom two weeks earlier than the early-blooming Harison's Yellow. And so with others: they are unique, hardy, vigorous. They need only to be fittingly placed to give to the garden a charm and distinction quite above the ordinary.

* The following two pages are published here with permission and by courtesy of Longmans, Green \& Co., New York., from their book, "Roses: Their History, Development, and Cultivation," by Rev. J. H. Pemberton (see page 105).

The reader will note how far removed from the original species are both the Tea and Hybrid Tea families, whereas, from many species there has been almost no development at all.

Equivalents of our common names to some of those on next pages:

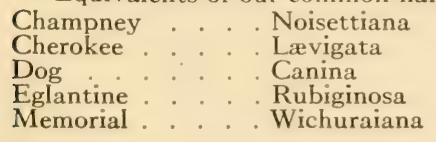

Moss . . . . . Muscosa

Musk . . . Moschata

Prairie .... Setigera

Scotch : . Spinosissima

Sweetbriar : . Rubiginosa 

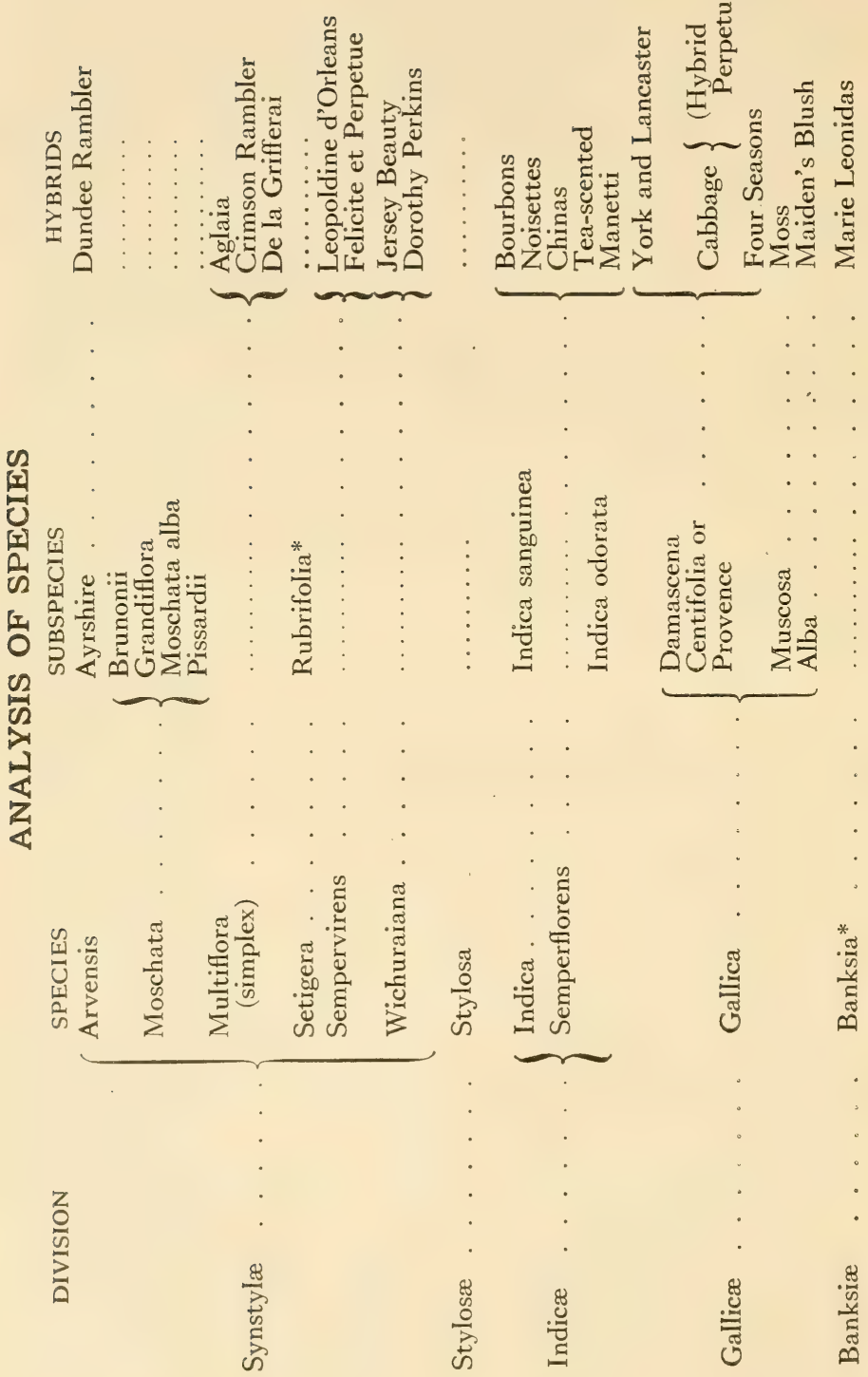

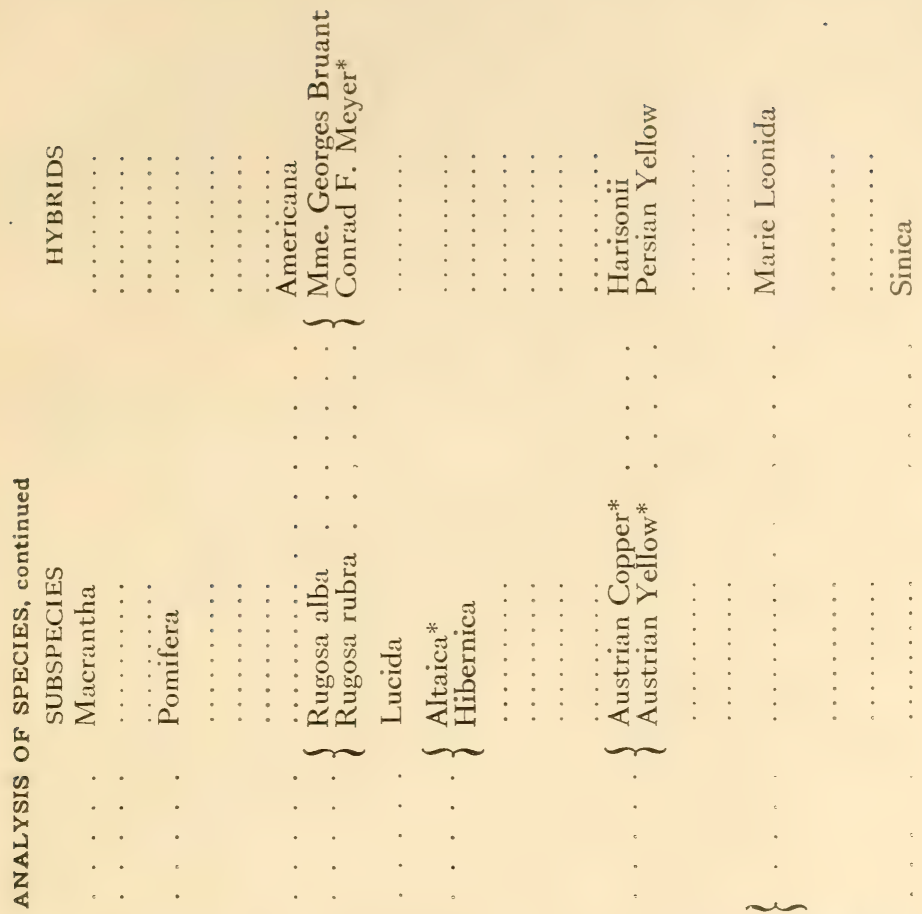

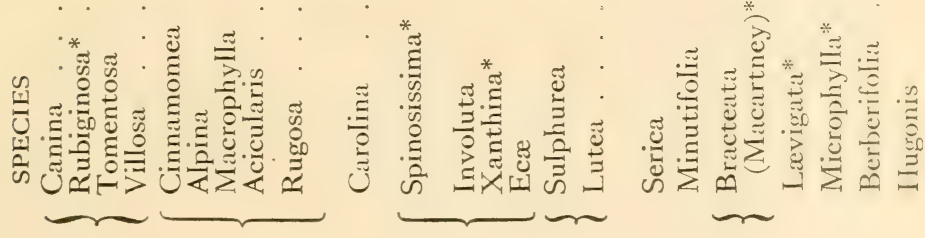

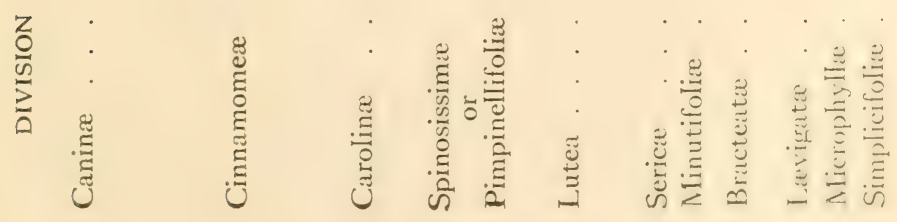




\section{Roses Arranged in Classes}

In order that the various classes may be studied better as to their characteristics, we hereunder group the more important varieties. French, German, and English authorities differ somewhat in placing a few kinds. Regarding the following lists, however, they are in substantial agreement: In case of differences we have relied upon the country of origin as our authority, e.g., Harison's Yellow.

\section{Alba}

*Mme. PIantier

Austrian Briar, or Lutea

$\begin{array}{ll}\text { Austrian Copper } & \text { *Harison's Yellow } \\ \text { Austrian Yellow } & \text { *Persian Yellow }\end{array}$

Hybrid Austrian Briar, or Pernetiana

Beaute de Lyon

Constance

*Juliet
Louise Catherine Breslau

*Mme. Edouard Herriot
Muriel Dickson

* Rayon d'Or

*Soleil d'Or

\section{Bengal \\ Archduke Charles \\ Douglas \\ Lucullus \\ Maddalena Scalarandis}

Bourbon

Appoline

*Beauty of Rosemawr

Burbank

Agrippina

* Birdie Blye (Heart of France)

Mrs. O. G. Orpen
*Champion of the World

*Mme. Eugene Marlitt

\section{Cbina}

*Hermosa

Pink Daily
Santa Rosa

*Souv. de Ia Malmaison *Queens Scarlet
Viridiflorat

\section{Damask}

Hybrid Perpetual .

Alfred Colomb

Alphonse Soupert

*American Beauty

*Anna de Diesbach $\dagger$

Antoine Wintzer

Ards Rover

Ball of Snow

Barbarossa

Baroness Rothschild
Baron de Bonstetten

Belle d'Orleans

Candeur Lyonnaise

Captain Christy

Captain Hayward

Charles Wagner

Cheshunt Hybrid

*Clio

Commander Jules

Gravereaux
Coquette des Alpes

Coquette des Blanches

Eugene Furst

Francois Levet

*Frau KarI Druschki†

*General Jacqueminot

George Arends

Giant of Battles

* Gloire de Chedane

Guinoisseau

\section{REFERENCE MARKS EXPLAINED}

The asterisk (*) indicates leading varieties described on pages 43 to 62 .

The dagger $(\dagger)$ indicates roses with two names and refers to list of synonymous roses, 
Hybrid Perpetual Roses, continued

Gloire de Margottin

*Gloire Lyonnaise

Glory of Paris

Heinrich Munch

*Hugh Dickson

*J. B. Clark

John Hopper

John Keynes

Jubilee

Lady Helen Stewart

La Reine

Admiral Schley

Admiral Ward

*Antoine Rivoire

*Arthur R. Goodwin

Augustus Hartmann

Autumn Tints

Avoca

Bessie Brown

*Betty

Brilliant

British Queen

Camoëns

Cardinal

Carine

*Chateau de Clos Vougeot

Cherry Page

Cherry Ripe

Chrissie MacKellar

Cissie Easlea

Cleveland

Colleen

Col. R. S. Williamson

Columbia

Comtesse Icy Hardegg

Countess Clanwilliam

Countess of Derby

Countess of Gosford

Countess of Shaftesbury

Dean Hole

Defiance

Dorothy Page-Roberts

Dr. J. Campbell Hall

Dr. O'Donel Browne

Duchess of Albanyt

Duchess of Sutherland

*Duchess of Wellingtont

Duchess of Westminster

EarI of Warwick

Ecarlate

Edgar M. Burnett

Edith Part
Mme. Charles Wood

Mme. Masson

MIle. Louise Crette

*Magna Charta

Marchioness of Lorne

Margaret Dickson

Marshall P. Wilder

*Mrs. John Laing

Mrs. R. G. SharmanCrawford

\section{Hybrid Tea}

Edward Mawley

Elizabeth Barnes

Ethel Malcolm

*Etoile de France

Eugene Boullet

Farbenkönigin

Florence E. Coulthwaite

Florence Forrester

*Florence Pemberton

*Francis Scott Key

F. R. Patzer

Frau Lilla

Rautenstrauch

Gainsborough

G. Amedee Hammond

*General MacArthur

*General-Superior Arnold Janssen

George C. Waud

*George Dickson

Gorgeous

Grace Molyneux

Grange Colombe

Grossherzog Friedrich

*Gruss an Teplitz†

Gustav Grunerwald

*Hadley

Hector MacKenzie

Helen Gould

H. E. Richardson

*Hoosier Beauty

H. V. Machin

Ideal

Iona Herdman

Irish Beauty

Irish Elegance

*Irish Fireflame

James Coey

Janet

*Jonkheer J. L. Mock

*Joseph Hill

Josephine

*Kaiserin Auguste

Victoria
Oakmont

Pauía Clegg

*Paul Neyron

*Prince Camille de Rohan $\dagger$

Rembrandt

*Roger Lambelin

Tom Wood

*Ulrich Brunner

Vick's Caprice

Victor Verdier

* Killarney

*Killarney Brilliant

*Killarney, White

Killarney Queen

King George V.

Königin Carola

*Lady Alice Stanley

*Lady Ashtown

Lady Greenall

*Lady Mary Ward

Lady Moyra Beauclerc

*Lady Pirrie

Lady Ursula

*La France $\dagger$

*La Tosca

*Laurent Carle

Leslie Holland

Liberty

Lieutenant Chaure

*Los Angeles

Louise Lilia

Lyon Rose

Mme. Abel Chatenay

Mme. Bernier d'Arnex

* Mme. Caroline Testout

*Mme. Charles Lutaud

Mme. Colette Martinet (Mme. Derepas-

$$
\text { Matrat) }
$$

*Mime. Edmond Rostand

Mme. Eugenie Boullet

Mme. Felix Faure

Mme. Jenny Gillemot

*Mme. Jules Bouché

*Mme. Jules Grolez

Mme. J. W. Budde

*Mme. Leon Pain

Mme. Maurice de Luze

*Mme. Melanie Soupert

Mme. P. Euler

Mme. Phillipe Rivoire

*Mme. Ravary

Mme. Schwaller

*Mme. Segond Weber 


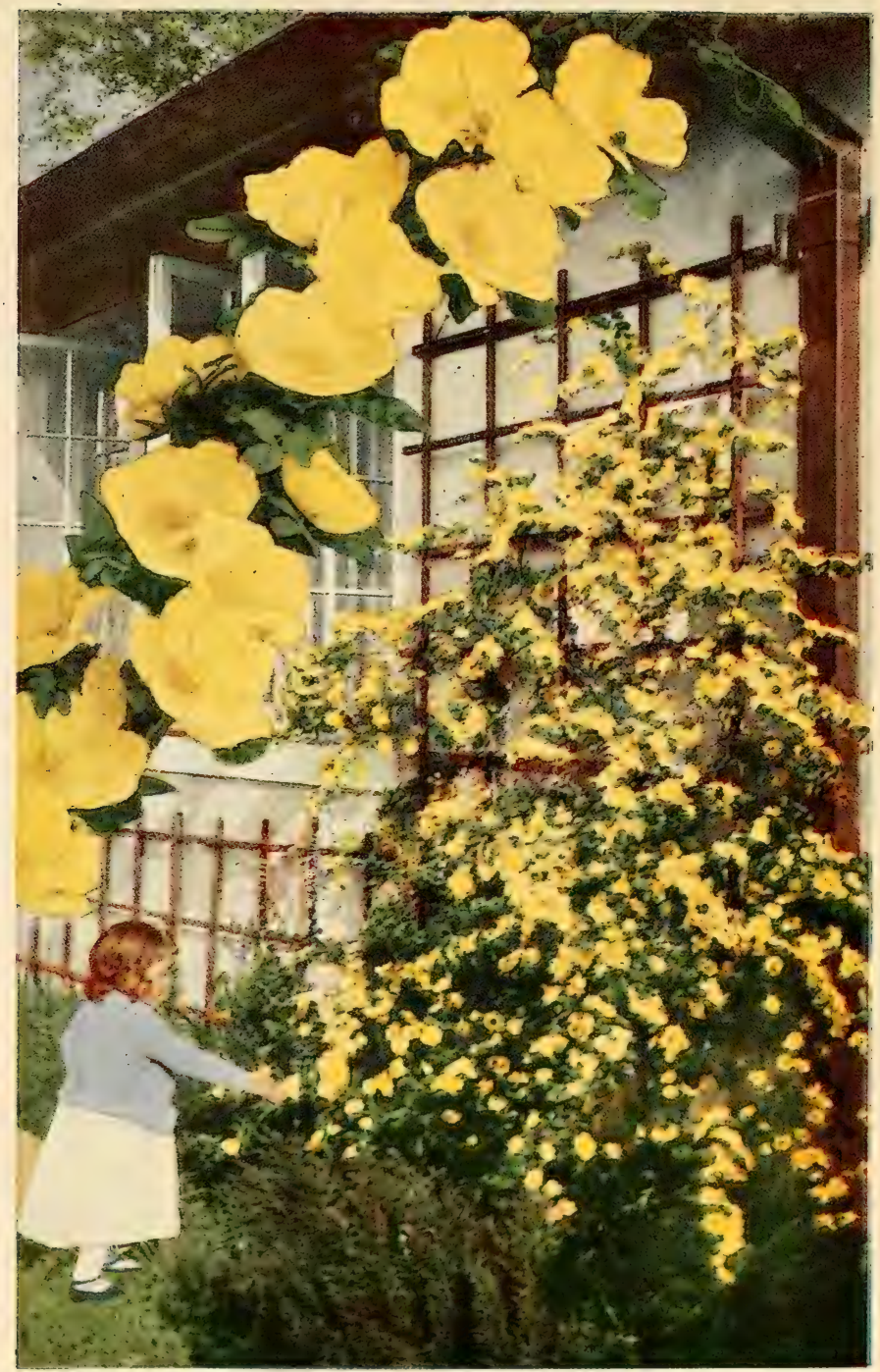

ROSA HUGONIS comes from Northern China and is perfectly hardy. Mr. E. H. Wilson, of the Arnold Arboretum, says of it: "It is an upright-growing Shrub with slender and spreading branches on which the fragrant flowers are borne in yard-long sprays of soft yellow. As I write in mid-November, the foliage is still on the Shrub and has assumed a dark purple tint." It blooms here two weeks ahead of any other rosenot a climber but a large bush rose which may be trained as here shown. 


\section{Hybrid Tea Roses, continued}

Mlle. Aug. Guinoisseau Mrs. Forde

MIle. Helena Cambier

Mlle. Marie Mascuraud

Mabel Drew

Magnafrano

Majestic

Mama Looymans

Marcella

Margaret Dickson Hamill

Mark Twain

Marquise de Querhoent

*Marquise de Sinety

*Mary, Countess of IIchester

Max Hesdorffer

May Miller

Meteor

Mevrouw Dora Van Tets

Milady

Miss Cynthia Forde

*Mrs. Aaron Ward

Mrs. A. E. Coxhead

Mrs. Ambrose Riccardo

Mrs. Amy Hammond

Mrs. Andrew Carnegie

Mrs. Archie Gray

*Mrs. A. R. Waddell

Mrs. Bertram J. Walker

Mrs. Chas. E. Pearson

Mrs. Chas. Hunter

Mrs. Chas. Russell

Mrs. Conway Jones

Mrs. Cornwallis West

Mrs. David Jardine

Mrs. David McKee

Mrs. Edward PowelI
Mrs. F. W. Vanderbilt

Mrs. George Gordon

Mrs. George Norwood

Mrs. George Shawyer

Mrs. Harold Brocklebank

Mrs. Harvey Thomas

Mrs. Hugh Dickson

Mrs. J. H. Welch

Mrs. MacKellar

Mrs. Maynard Sinton

Mrs. Moorefreld Storey

Mrs. R. D. McClure

Mrs. Richard Draper

Mrs. Robert Garrett

Mrs. Sam Ross

Mrs. T. Hillas

Mrs. Theo. Roosevelt

*Mrs. Wakefield Christie-Miller

Mrs. Wemyss Quin

*My Maryland

Natalie Bottner

Neervelt

Nerissa

Old-Gold

Olivia

*Ophelia

Panama

Peerless

Pernet's Triumph

*Pharisäer

Pilgrim

President Vignet

Premier

Prima Donnat
Prince Engelbert

Charles d'Arenberg

Prince de Bulgarie

Princess Bonnie

Queen Beatrice

Queen Mary

*Radiance

Red Columbia

Red-Letter Day

* Red Radiance

Reine Carola de Saxe

Reine Marguerite. d'Italie

Rene Robbins

Renee Wilmart Urban

Rhea Reid

Richmond

Seabird

Souv. de E. Guillard

*Souv. de Gustave Prat

*Souv. du Pres. Carnot

Souv. of Wootton

Spectacular $\dagger$

*Sunburst

Taft Rose

Veluwezoom $t$

Viscountess Enfreld

Viscountess Folkestone

Virginia R. Coxe $\dagger$

Walter Speed

Waltham's Scarlet

W. E. Lippiatt

Wellesley

West Grove

*White Killarney

William Cooper

*Williain Shean

*Willowmere

Winnie Davis

There are in this list other promising varieties not yet sufficiently tested to recommend.

BIanche Moreau

Blanche Roberts

Caroline Marneis

Comtesse de Murinais

Ennchen Müller

*Baby Dorothyt

*Baby Rambler†

Betsy Van Nes

Clotilde Soupert

Echo

*EIlen PouIsen

*Erna Teschendorff
Moss

*Crested Moss

Crimson Globe

Eugene de Savoi

Glory of Mosses

\section{Polyantha}

Etoile de Mai

F. J. Grootendorst

*George Elger

Goldfinch

*Gruss an Aachen

*Katharina Zeimet

Leonie Lamesch

*Louise Waltert
*Henri Martin

Mousseline

Princess Adelaide

Salet

*Mme. Norbert Levavasseurt

* Mile. Cecile Brunner

*Maman Levavasseurt

*Marie Pavie

Mignon†

Mignonette

Miniature 
Polyantba Roses, continued

Mosella, T.P.

Mrs. W. H. Cutbush $\dagger$

Mme. Jules Gouchault

Mrs. Taft $\dagger$
*OrIeans

Perle d'Or

Sweetheart

*Tip-Top
Triomphe Orleanais

White Soupert

Yellow Soupert

Yvonne Rabier

\section{Rugosa and Hybrids}

*Agnes Emily Carman Alice AIdrich

Amelia Gravereaux

Beaute Poitevine

* Blanc Double de Coubert

Chas. F. Worth

*Conrad Ferdinand Meyer

\section{Ada Carmody}

*Alexander Hill Gray

Alliance Franco-Russe

Anna Oliver

Aurora

Beaute Inconstante

Betty Berkeley

Blumenschmidt

Bon Silene

Bride

*Bridesmaid

Canadian Belle

Catherine Mermet

Comtesse Riza du Parc

Comtesse SophyTorby

Coquette de Lyon

Corallina

Corinna

Cornelia Cook

David PradeI

*Devoniensist

Dr. Grill

*Duchesse de Brabant

Enchantress

Etoile de Lyon

Fr. von Marschall

General R. E. Lee

G. Nabonnand

Golden Gate

*Harry Kirk

Helen Good

Henry M. Stanley

*Hugo Roller

Isabella Sprunt

Ivory
Hansa

Mme. Chas. Frederick Worth

Max Graf

*New Century

Nova Zembla

Regina Badet

Repens alba

Roseraie de l'Hay

\section{Tea}

J. B. Varonne

Königin WilheImina

*Lady Hillingdon

Lady PIymouth

Lady Roberts

Lena

Letty Coles

Mme. Antoine Mari

*Mme. Camille

Mme. Caroline Kuster

Mme. C. P. Strassheim

Mme.Derepas-Matrat $\dagger$

Mme. de Vatrey

Mme. de Watteville

Mme. Elie Lambert

Mme. F. Kruger

Mme. Hoste

Mme. Jean Dupuy

Mme. Jos. Schwartz

Mme. Lambard

Mme. Margottin

Mme. Olga

Mme. Rene Gerard

Mme. VermoreI

Mme. Welche

MIle. J. Phillips

*Madison

*Maman Cochet $\dagger$

* Maman Cochet, White

Marie Guillot

Marie Lambert

*Marie Van Houtte

Marion Dingee

Medea

Bengal, Climber

Empress of China
Roseraie Parfum de I'Hay

Rosa Tetankaba

*Rugosa alba

Rugosa magnifica

*Rugosa rubra

*Sir Thomas Lipton (White Century)

Souv, de Pierre Leperdrieux

*Miss Alice de Rothschild

Molly S. Crawford

*Mrs. B. R. Cant

Mrs. Campbell HaII

Mrs. Foley-Hobbs

Mrs. Herbert Hawksworth

Mrs. Herbert Stevens

Mrs. Hubert Taylor

Mrs. Myles Kennedy

Mrs. S. T. Wright

Muriel Grahame

Nita Weldon

Papa Gontier

*Perle des Jardins

Perle des Jaunes

Princess Hohenzollern

Princess de Sagan

Queen Olga of Greece

Queen, Thet

Rainbow

Rose d'Evian

* Safrano

Sombreuil

Souv. de Catherine Guillot

*Souv. de Pierre Notting

Sulphurea

Sunrise

Sunset

White Maman Cochet

*Wm. R. Smith $\dagger$

Winter Gem 


\section{Climbing Hybrid Tea}

* Carmine Pillar (Paul's) *Lady Ashtown, CI.

* Gruss an Teplitz, CI.

* Kaiserin Auguste Victoria, Climbing Killarney, White, Cl. Killarney, Climbing

Cumberland Belle

AgIaia

*American Pillar

*Aunt Harriet

Flower of Fairfield

Geisha

*Alister Stella Gray† Bridesmaid, Climbing Chromatellat

Cloth of Gold†

MIle. Cecile Brunner, Climbing

Species

Hugonis

Moyesii

Xanthina

Devoniensis, Climbing Gloire de Dijon Isabella Gray James Sprunt Climbing Climbing

Mme. Wagram

*Le Poilu

\section{Multiflora}

Miss Messman

Mosella, Climbing

Psyche

Rambler, Crimson

\section{Noisette}

Lamarque

*Marechal Niel

Clotilde Soupert, Climbing

Amy Robsart

Anne of Geierstein

*Mme. Driout Climbing
La France, Pink, CI.

* Mme. CarolineTestout,

$$
\text { Climbing Moss }
$$

*Philadelphia Rambler

*Mme. Alfred Carriere

Meteor, Climbing

*Mrs. Robert Peary

My Maryland, CI.

Reine Marie Henriette, Climbing

Souv. of Wootton, CI.

Wichmoss

Ramblerst

*Tausendschön†

Thalia

Trier

Wartburg

Reve d'Or

Solfatare

*Wm. Allen Richardson

Climbing Polyantha

Frau Berta Guertler, Climbing

Sweetbriar

Lady Penzance

*Sweetbriar, Common

\section{Climbing Tea}

Mme.Jules Gravereaux

* Maman Cochet, Pink,
Maman Cochet, White, Climbing

Perle des Jardins, CI.

Pillar of Gold.

\section{Wichuraiana and Hybrids}

Alba rubrifolia
*Alberic Barbier
*American Beauty, CI.
*Aviateur Bleriot
*Bess Lovett
Casimir Moulle
*Christine Wright
*Coronation
Daybreak
Debutante
Dorothy Dennison $\dagger$
*Dorothy Perkinst
*Dorothy Perkins,
White
*Dorothy Perkins,
Red†
*Dr. W. Van Fleet

*Emily Gray

Evangeline

Evergreen Gem

* Excelsa

Farquhar

*Gardenia

*Hiawatha

Jersey Beauty

Juanita

Lady Duncan

Lady Gayt

Longwood

Manda's Triumph

*Mary Lovett†

* May Queen

Minnehaha

Mrs. M. H. Walsh
*Paul's Scarlet Climber

Pearl Queen

Prof. C. S. Sargent

Robert Craig

*Ruby Queen

*Shower of Gold

*Silver Moon

Sodenia

South Orange Perfection

Sweetheart

Universal Favorite

W. C. Egan

Wichmoss

*Wichuraiana

Wichuraiana variegata 


\section{Index}

Abundance, 80 .

Acicularis, 109.

Ada Carmody, I 4.

Admiral Aaron Ward, 8ז.

Admiral Ward Rose, 79, I I I.

Admiral Schley, i I I.

Ennchen Muller, Ir3.

Aglaia, 108 , I 5 .

Agnes Emily Carman, 43.

Agrippina, 1 Io.

Alba, 108.

Alba rubrifolia, I 5 .

Alberic Barbier, 43.

Alexander Hill Gray, 43.

Alfred Colomb, 79, I Io.

Alice Aldrich, 1 i 4 .

A I ister Stella Gray (Golden Rambler), 43.

Alliance Franco-Russe, I 14.

Alphonse Soupert, I 10.

Alpina, 109.

Altaica, 109.

Altitude, Consideration of, 6 .

Amateur Teyssier, 8I.

Americana, rog.

Amelia Gravereaux, II4.

American Beauty (Mme. Ferd. Jamin), 44.

American Beauty, Climbing, 44 .

American Pillar, 44.

American Rose Society, 92.

Amy Robsart, I I 5 .

Analysis of Species, 107I09.

Anna de Diesbach, 44.

Anna Oliver, 114 .

Anne of Geierstein, I 15.

Antoine Rivoire, 44, 89.

Antoine Wintzer, I 10.

Aphides or green-fIy, How and when to destroy, 6, 30 .

Appoline, I Io.

Archduke Charles, I 10.

Ards Rover, i Io.

Arsenate of lead, How to use, 6.

Arthur R. Goodwin, 44.

Arvensis, 108.

Ashes, Use of Coal, 6.

Attar of Roses, 102.

Avenue effect with roses, 13.

Augustine Guinoisseau, 81.

Augustus Hartmann, I I I.

Aunt Harriet, 44.

Aurora, II 4 .

Austrian Copper, I09, I ro.

Austrian Yellow, I09, I 10.

Autumn Tints, I I I.

Aviateur Bleriot, 44.

Avoca, 77.

Ayrshire, 108.

Baby Dorothy (Maman Levavasseur), 44, 106.
Baby Rambler, Red (Mme. Norbert Levavasseur), $44,106$.

Baby Ramblers, 44, 106.

B a by T a usendschön (Louise WaIter), 106.

Bailey, Prof. Liberty H.,.38.

Ball of Snow, ro6, I 10.

Banksiæ, 108.

Banksia, I 8 .

Barbarossa, I 10.

Baronne Provost, 88.

Baron de Bonstetten, I Io.

Baroness Rothschild, 79, I 10.

Beaute Inconstante, I I 4.

Beaute Poitevine, I I 4.

Beauty of Rosemawr, 44 .

Beds, Rose, shape and size, I I

Belle d'Orleans, i 10.

Berberifolia, Iog.

Bessie Brown, i I I.

Bess Lovett, 44.

Betsy Van Nes, Ir3.

Betty, 44.

Betty Berkeley, I I 4 .

Bibliography, I05.

Birdie Blye, 44 .

Black-Leaf 40, 7, 30 .

Black-spot, 30.

BIanc Doubie de Coubert, 44.

Blanche Moreau, 44.

Blanche Roberts, I I3.

Blumenschmidt, I 14 .

Bone-dust, When to use, 17.

Bon Silene, I I 4 .

Books about roses, I05.

Bordeaux Mixture, 7, 30.

Bourbons, 108.

Boutonniere, 42 .

Bracteata, I09.

Bracteatæ, I09.

Bride, I I 4 .

Bridesmaid, 44.

Bridesmaid, Climbing, I 15 .

Brilliant, I I $x$.

British Queen, I I I.

Bruant, M. Georges, 86.

Brunoni, ro8.

Budded roses, 36.

Budding roses, 36 .

Bud-rot, 30.

Burbank, I ro.

Burying, for winter, 27.

Cabbage, 108.

Calendar of operations, $6,7$.

Camoëns, I I I.

Canadian Belle, I 14.

Candeur Lyonnaise, I 10.

Canina, rog.

Canina roses for grafting, 36 .

Caninæ, rog.

Captain Christy, I $\mathbf{x}$ o.
Captain Hayward, 110.

Cardinal, II 1 .

Carine, I I I.

Carman, Robert C. S., 86.

Carmine Pillar, 44.

Carolina, rog.

Carolinæ, rog.

Caroline Marneis, I I3.

Catherine Mermet, II4.

Casimir Moulle, i 5 .

Cecile Brunner. See MIle. Cecile Brunner, 53.

Centifolia, 108.

Champion of the World, 46.

Chapman, Mr., ornithologist, ro.

Charles Dingee, ro6.

Charles F. Worth, I I 4 .

Charles Wagner, i io.

Chateau de Clos Vougeot, 46,89 .

Cherry Page, II I.

Cherry Ripe, I I .

Cheshunt Hybrid, II I.

Chinas, 108.

Chrissie MacKellar, I I I.

Christine Wright, 46,83 .

Cinnamomea, rog.

Cissie Easlea, I II.

Classes, 39, I I $0-1$ I 5 .

Cleveland, $\mathbf{I}$ I .

Clio, 46.

Clotilde Soupert, 113.

Clotilde Soupert, CI., I I 5 .

Colleen, I I I.

Color plates, I, 12, 21, 32, $40,45,51,58,63,70,78$, $87,94,103$, I 12 , I 17.

Col. R. S. Williamson, i i .

Columbia, 4, 46, 77, 79, 80 .

Commander Jules Gravereaux, I I I.

Comtesse de Murinais, I 13.

Comtesse Icy Hardegg, I I I.

Comtesse Riza du Parc, I 14.

Comtesse Sophy Torby, I 14.

Conrad F. Meyer, 46, rog.

Conserving moisture, 25 .

Constance, $8 \mathrm{I}$.

Contents, table of, 2 .

Cooper, Rev. A. E., 100.

Coquette des Alpes, I I I.

Coquette des Blanches, I I I.

Coquette de Lyon, I I 4.

Corallina, I 14.

Corinna, I I 4.

Cornelia Cook, I I4.

Coronation, 46

Countess Clanwilliam, I I I.

Countess of Derby, III.

Countess of Gosford, 66.

Countess of Oxford, 88.

Countess of Shaftesbury, I I I .

Crested Moss, 46.

Crimson Globe, I13.

Crimson Rambler, I o8, I 5 . 


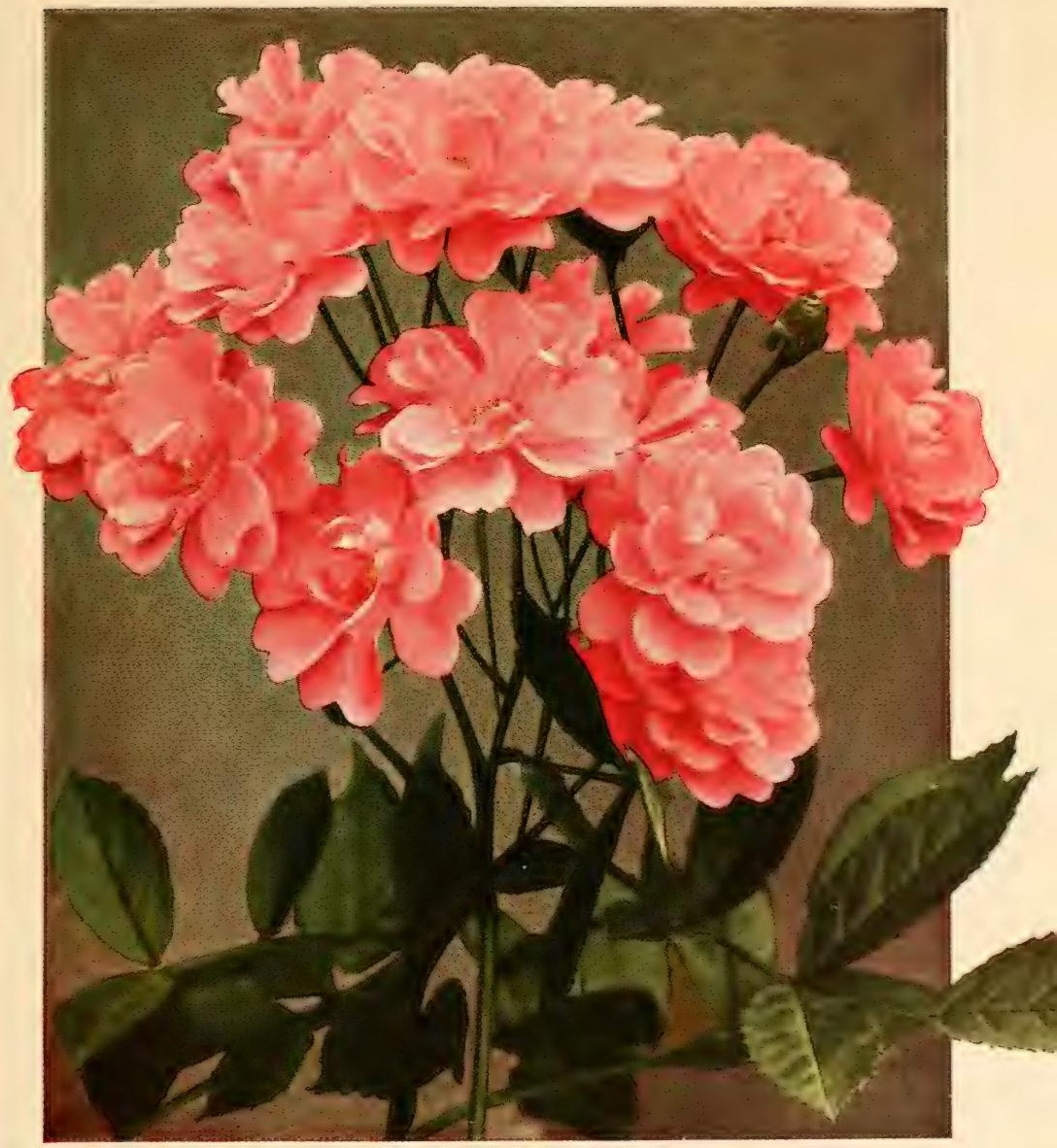

PINK BABY RAMBLER, or BABY DOROTHY, is a good representative of the Baby Rambler family, now available in an almost endless variety of colors, including white and all shades of pink and red.

This is the dwarf-growing Polvantha Rose so popular now for edging and also for bedding. It is recommended for use in place of geraniums, because it is so hardy that it does not need to be replanted yearly. 
Cumberland Belle, I I 5 .

Currey, J. A., 77.

Daily Mail. ( $M$ me. Edouard Herriot), 53 .

Damascena, 108.

David Pradel, I 14 .

Daybreak, II5.

Dean Hole, I o, 89, I I I.

Debutante, I I 5 .

Defiance, I I I.

De Ia Grifferaie, ıo8.

Devoniensis, 46.

Dr. Grill, i 14 .

Distance apart, II.

Dr. J. Campbell HaII, I I I.

Dr. O'Donel Browne, I I I.

Dr. W. Van Fleet, 47.

Dr. W. Van Fleet, White, I 5 .

Dorothy Dennison, 106, I 5 .

Dorothy Page - Roberts, I I I.

Dorothy Perkins, 47, 106, I 08 .

Dorothy Perkins, Red, 106.

Dorothy Perkins, White, 47.

Douglas, I 10.

Drainage, I0-I 4 .

Duchesse de Brabant, 47.

Duchess of Al̉bany, I I I.

Duchess of Sutherland, I I I.

Duchess of Wellington, 4 ,

Duchess of Westmirster, 89 , I I I.

Dundee Rambler, 108.

Dutch Beauty, I 06.

EarI of Warwick, 89, I I I.

Ecæ, rog.

Ecarlate, 89, I I I.

Echo, I 13.

Edgar M. Burnett, I I I.

Edith Part, I I I.

Edward Mawley', I I I.

Egan, W. C., 26, 85 .

Ellen Poulsen, 47.

Ellen Willmott, 82 .

Eliot, Charles W., 9I

Elisa Robichon, 83.

Elizabeth Barnes, I I I .

Emily Gray, 57.

Empress of China, I4.

Enchantress, I 14 .

Erna Teschendorff, 47.

Ethel Malcolm, I I I.

Etoile de France, 47.

Etoile de Lyon, I I 4 .

Etoile de Mai, I 13.

Eugene Boullet, III.

Eugene de Savoi, I I3.

Eugene Furst, III.

Euphrosine, Io6.

Evangeline, I 15.

Evergreen Gem, I 15.
Excelsa, 47.

Expert opinions, 77-9I.

Farbenkönigin, 89.

Farquhar, I 15 .

F. E. Coulthwaite, I I I.

F. J. Grootendorst, 86, I 13.

Felicite et Perpetue, I08.

Fertilizers of all kinds, 16.

Florence Forrester, I I $x$.

Florence Pemberton, 48, 89 .

Flower of Fairfield, I I 5 .

Formal garden, illus., I3.

Four seasons, 108.

Fragrant roses, 93.

Francois Levet, I I I.

Francis Scott Key, 48.

Frau Berta Guertler, I Is.

Frau KarI Druschki, 4, 48.

Frau Lilla Rautenstrauch, III.

F. R. Patzer, I I I.

Fr. von Marschali, I 14.

Fungoid troubles, 7 .

Gainsborough, I I I.

Gallica, 108.

Gallicæ, 108 .

G. Amedee Hammond, I I I.

Garden Favorite, 86.

Gardenia, 48.

Geisha, I 5 .

GeneraI Jacqueminot, 48.

General MacArthur, 48, 89 .

General R. E. Lee, I I 4 .

General - Superior Arnold Janssen, 48 .

George Arends, 48, 83.

George C. Waud, 82 .

George Dickson, 48, 79 .

George Elger, 48.

Giant of Battles, I I I.

Giant Tree Rose, illustration of, 98 .

GIoire de Chedane Guinoisseau, 48 .

Gloire de Dijon, 26,77 .

Gloire de Margottin, I 1 I.

Gloire Lyonnaise, 4 ).

GIory of Mosses, 113.

Gloire de Paris, I o6.

Gloire des Polyanthas, 80.

Glory of Paris, i I I.

G. Nabonnand, I I 4 .

Goldfinch, 113 .

Golden Gate, i 14.

Golden Rambler (see Alister Stella Gray).

Golden rules, 29.

Gorgeous, I I I.

Grace Molyneux, I I I.

Grafted roses, 36.

Grandiflora, 108.

Grange Colombe, 77, 79.

Gravereaux, M. Jules, 24.

Green-fly, Aphis or, How to destroy, 6,30 .

Green Rose, I 66.

Grossherzog Friedrich, 89.

Gruss an Aachen, 49.
Gruss an Teplitz, 40.

Gruss an Teplitz, CI., 49.

Gustav Grunerwald, 89, I I I .

Hadley, 49.

Hansa, I I 4 .

Harisonï, Iog.

Harison's Yellow, 49.

Harry Kirk, 49.

Hector MacKenzie, I I I.

Hedges, rose, 74 .

Heeling-in roses, 19.

Heinrich Munch, I I I.

Heinrich Schultheis, 79.

Helen Good, I 13 .

Helen Gould, I I I.

H. E. Richardson, I I r.

Henri Martin, 49.

Henry M. Stanley, I I 4 .

Hermosa, 49.

Hiawatha, 49.

Hibernica, I09.

Hoosier Beauty, 49.

Huey, Dr. Robert, 82.

Hugh Dickson, 49.

Hugonis, 50.

Hugo Roller, 50.

H. V. Machin, I I I.

Hybridizing, A few words about, 104 .

Ideal, I I I .

Ideals, 5 .

Indica, 108 .

Indicæ, 108 .

Indica odorata, 108.

Indica sanguinea, 108.

Insect enemies, 30.

Involuta, roo.

Iona Herdman, I I I.

Irish Beauty, I I I.

Irish Elegance, I I $\mathrm{r}$.

Irish Fireflame, 50.

Isabella Sprunt, I I 4 .

Ivory, I 4 .

J. B. Varonne, I I 4 .

James Coey, I I I.

Janet, I I I.

J. B. Clark, 50, 79 .

Jeannette Heller, io6.

Jersey Beauty, I09, I I 5.

J. H. McFarland, 92, 93.

Jessie, 8o.

John Hopper, I I I .

John Keynes, I I I.

Jonkheer J. L. Mock, 50, $79,89$.

Joseph Hill, 50, 81

Josephine, I I I.

Juniata, I I 5 .

Jubilee, I I I.

Jules Margottin, 79.

Juliet, 50 .

Kaiserin Aususte Victoria, 50.

Kaiserin Auguste Victoria, Climbing, I 15 .

Katharina Zeimet, 50. 
Killarneys, 50, 89, ro6.

Killarney Brilliant, 50 .

Killarney Queen, I I I.

Killarney, Striped, 106.

Killarney, Climbing, I 15.

Killarney, White, 50.

Killarney, White, CI., I 15.

King George V., I I I.

Königin Carola, I I I.

Königin Wilhelmina, I I4.

Labeling, 22, 23.

Labels, copper, 22; zinc; celluloid, stake, gardenclub, Mann, Simplex, 23.

Lady Álice Stanley, 50, 89.

Lady Ashtown, 50, 79, 89.

Lady Ashtown, CI., 50.

Lady Duncan, Ir4.

Lady Gay, I I 4.

Lady Godiva, 106.

Lady Greenalî, I I I.

Lady Helen Stewart, I I I .

Lady Hillingdon, 50, 83 .

Lady Mary Ward, 50.

Lady Moyra Beauclerc, I I .

Lady Penzance, I I 5.

Lady Pirrie, 50, 89 .

Lady Plymouth, I 4 .

Lady Roberts, I 14.

Lady Ursula, 79, 89, 1 I 1 .

La Fiamme, 80.

La France, 52, 79, I 06.

La France, Climbing, I 5.

La France, Red (Duchess of Albany), ro6.

La France, Striped, ro6.

La France, White (Augustine Guinoisseau), 106.

Lamarque, I 15.

La Reine, I I I.

La Reine des Neiges, 106.

La Roseire, ro6.

La Tosca, 52, 80.

Laurent Carle, 52, 79, 89.

Lævigata, I 00.

Lævigatæ, ro9.

Lena, I 14 .

Leonie Lambert, I I I.

Leonie Lamesch, I I3.

Leopoldine d'Orleans, Io8.

Le Poilu, 52.

Leslie Holland, I I I.

Letiy Coles, i 14.

Liberty, I I I.

Lieutenant Chaure, 89, I I I.

Longwood, 114.

Los Angeles, 52, 82 .

Louise C. Breslau, 52, 89.

Louise Lilia, I I I.

Louis Van Houtte, 79.

Louise Walter, 52.

Lucida, rog.

Lucullus, I 10.

Lutea, 100.

Luteæ, ro9.

Lyon Rose, I I I.

Macartney, rog.
McFarland, J. Horace, 92, 93, 105.

Macrantha, Iog.

Macrophylla, 109.

Mme. Abel Chatenay, I I r.

Mme. Alfred Carriere, 52.

Mme. Angel Vayssett, Io6.

Mme. Antoine Mari, II 4 .

Mme. Bernier d'Arnex, I I I.

Mme. Camille, 52.

Mme. Caroline Kuster, I 14.

Mme.C.P.Strassheim, I I 4 .

Mme. Caroline Testout, 52,82 .

Mme. Caroline Testout, Climbing, 53, 80 .

Mme. Chas. Frederick Worth, I I 4 .

Mme. Charles Lutaud, 53.

Mme. Charles Wood, I I I.

Mme. Colette Martinet, I I I.

Mme. Derepas - Matrat, I06, 114.

Mme. de Vatrey, I I 4.

Mme. de Watteville, i i4.

Mme. Driout, I 15.

Mme. Ed. Rostand, 53, 89

Mme. Edouard Herriot (Daily Mail Rose), 53.

Mme. Elie Lambert, I 4.

Mme. Eugenie Boullet, III.

Mme. Eugene Marlitt, 53.

Mme. Felix Faure, I I I.

Mme. F. Kruger, I I4.

Mme. Gabriel Luizet, 79.

Mme. Georges Bruant, I09.

Mme. Hector Leuillot, 82.

Mme. Hoste, I I 4 .

Mme. Jean Dupuy, I r 4 .

Mme. Jenny Gillemot, 89 , I I I.

Mme. Jos. Schwartz, I 14.

Mme. Jules Bouché, 79, 8o, 89 , I I I.

Mme. Jules Gouchault, II 4 .

Mme. Jules Gravereaux, I 5 .

Mme. Jules Grolez, 53.

Mme. J. W. Budde, I Ir.

Mme. Lambard, I I 4 .

Mme. Leon Pain, 53, 89.

Mme. Margottin, x 4 .

Mme. Masson, I I I.

Mme. Maurice de Luze, 113.

Mme. Melanie Soupert, 53, 82,89 .

Mme. Norbert Levavasseur (Red Baby Rambler), 113 .

Mme. Olga, I 4.

Mme. Philippe Rivoire, II3.

Mme. P. Euler, I13.

Mme. Plantier, 53.
Mme. Ravary, 53, 89.

Mme. Rene Gerard, II4.

Mme. Segond Weber, 53, 82.

Mme. Vermorel, I I 4 .

Mme. Wagram, i 5 .

Mme. Welche, I 14 .

Mme. Zelia Bourgeois, 80.

Mlle. Augustine Guinoisseau, I 13 .

MIle. Cecile Brunner, 53.

MIle. Cecile Brunner, Climbing, $x$ I 5 .

MIIe. Helena Cambier, I 13.

Mlle. J. Phillips, I 44.

MIle. Louise Crette, I I r.

MIle. Marie Mascuraud, 113.

Mabel Drew, I 13.

Madison, I I 4.

Maddalena Scalarandis, I 10.

Magna Charta, 56.

Magnafrano, I 13 .

Magnifica, I 14.

Magnolia Rose, I 06.

Maiden's Blush, 108.

Majestic, 89 .

Mama Looymans, I13.

Maman Cochet, Pink, 56.

Maman Cochet, Pink, Climbing, 56 .

Maman Cochet, White, 56.

Maman Cochet, White, Climbing, I 5 .

Maman Cochet, Yellow, I06.

Maman Levavasseur (Baby Dorothy), 106, I 13 .

Manda's Triumph, II 4 .

Manetti, ro8.

Manetti, for grafting, 36 .

Manure, liquid, When to apply, 16.

Map of U. S. A., r 8 .

Marcella, I I 3.

Marchioness of Lorne, I I I.

Marechal Niel, 56 .

Margaret Dickson, I I I.

Margaret Dickson Hamill, 113.

Marie Finger, 79.

Marie Guillot, I14.

Marie Lambert, I I 4 .

Marie Leonidas, ro8.

Marie Pavie, 56.

Marie Van Houtte, 56.

Marion Dingee, I I 4 .

Mark Twain, Ir 3 .

Marquise de Querhoent, I 3 .

Marquise de Sinety, 56.

Marshall P. Wilder, i I I.

Mary, Countess of Ilchester, 56.

Mary Lovett, 56.

Mawley, Edward, 29.

Max Graf, 88, I I 4 .

Max Hesdorffer, I 13.

May Miller, Ir3.

May Queen, 57. 
Medea, I I 4 .

Meteor, I 13.

Meteor, Climbing, I I 5 .

$\mathrm{Mice}, \mathrm{How}$ to guard against, 27.

Microphylla, rog.

Microphyllæ, I 09 .

Mignon, 106, 113 .

Mignonette, I I4.

Milady, I 13.

Mildew, How to remedy, 30.

Mills, Rev. E. M., 80-97.

Miniature, I 14.

Minnehaha, I 15 .

Minutifolia, 109.

Miss Alice de Rothschild, 57.

Miss Cynthia Forde, 79, I13.

Miss Kate Moulton, 79.

Miss Messman, I 5 .

Moisture, How to conserve, 25.

Moles, How to guard against, 27.

Molly Sharman-Crawford, I 4.

Moschata, 108.

Moschata alba, 108.

Mosella, I 14.

Mosella, Climbing, I 5 .

Moss, 108.

Mousseline, I 13.

Moyesii, 75 .

Multiflora simplex, Io8.

Multifoliæ, 109.

Mrs. Aaron Ward, 57, 89.

Mrs. A. E. Coxhead, II3.

Mrs. Ambrose Riccardo, I 13.

Mrs. Amy Hammond, I 13 .

Mrs. Andrew Carnegie, I 13.

Mrs. Archie Gray, I 13.

Mrs. A. R. Waddell, 57, 89.

Mrs. B. R. Cant, 57.

Mrs. Bertram J. Walker, I 13 .

Mrs. Campbell Hall, I I4.

Mrs. Chas. E. Pearson, 113.

Mrs. Chas. Hunter, II3.

Mrs. Charles Russell, I I3.

Mrs. Conway Jones, I 13 .

Mrs. Cornwallis West, II3.

Mrs. David Jardine, I 13.

Mrs. David McKee, I 13.

Mrs. Edward Powell, I I3.

Mrs. Forde, I 13.

Mrs. Foley-Hobbs, I 14.

Mrs. F. W. Vanderbilt, 89 , I 13.

Mrs. George Gordon, I I3.

Mrs. George Norwood, I 13.

Mrs. George Shawyer, 89, I 13.

Mrs. Harold Brocklebank, I 13.

Mrs. Harvey Thomas, I 13.

Mrs. H. Hawksworth, I 14 .

Mrs. Herbert Stevens, I 14 .
Mrs. Hubert Taylor, I 14.

Mrs. Hugh Dickson, 113.

Mrs. John Laing, 57.

Mrs. J. H. Welch, I 13.

Mrs. MacKellar, 82, I 13.

Mrs. Maynard Sinton, I 13.

Mrs. M. H. Walsh, i 5 .

Mrs. Moorefield Storey, I 13 .

Mrs. Myles Kennedy, I I 4 .

Mrs. O. G. Orpen, I Io.

Mrs. Paul, 86.

Mrs. R. D. McClure, I 13.

Mrs. Richard Draper, 113.

Mrs. R. G. Sharman Crawford, I I I.

Mrs. Robert Garrett, I I3.

Mrs. Robert Peary, 57.

Mrs. Sam Ross, I 13.

Mrs. S. T. Wright, i 14.

Mrs. Taft, I 14 .

Mrs. Theo. Roosevelt, I 13.

Mrs. T. Hillas, I 13.

Mrs. W. Christie Miller, $57,89$.

Mrs. W. H. Cutbush, 80, I 06 , I 14.

Mrs. Wemyss Quin, I 13

Mrs. W. J. Grant, 106.

Mulch, dust 6; grass, leaves, sawdust, peatmoss, 7, 25 .

Mulching, 25 .

Multiflora roses for grafting, 36.

Municipal rose-gardens, 95.

Muriel Dickson, I I o.

Muriel Grahame, i i 4 .

Muscosa, 108.

My Maryland, 57.

My Maryland, Ci., i 15.

Natalie Bottner, II3.

Neervelt, II3.

Nerissa, I 13.

New Century, 59.

Nicotine, 6.

Nita Weldon, II4.

Noisettes, ro8.

Nova Zembla, ri4.

Oakmont, I I I.

Old-Gold, i 13.

Olivia, I 13.

Ophelia, 59, 77, 82, 89 .

Orleans, 59.

Orpet, Mr., 26.

Oskar Cordel, 83.

Own-root roses, 36.

Page-Roberts, Rev. F., I4. Panama, I 13.

Pansies, 25.

Papa Gontier, I14.

Paradise, 80.

Parker, G. A., 91, 95.

Paula Clegg, 8I.

Paul Neyron, 59.

Paul's Carmine Pillar, I 5.

Paul's Scarlet Climber, 59.
PearI Queen, 1 I 5.

Peat moss, 25.

Peerless, I 13.

Pemberton, Rev. J. H., 105.

Perle d'Or, 1 I 4.

Perle des Jardins, 59.

Perle des Jardins, CI., I I 5 .

Perle des Jaunes, I I 4

Pernet's Triumph, I 13.

Persian Yellow, 59, 109.

Pharisaer, 59.

Philadelphia Rambler, 59.

Pilgrim., 76.

Pillar of Gold, 1 I 5.

Pimpinellifoliæ, rog.

Pink Daily, I ro.

Pink MemoriaI, Dbl. (Universal Favorite), II5.

Pissardii, $\mathbf{1} 08$.

Plant-food, 7.

Plant roses, When to, 17.

Plant roses, Depth to, 20.

Planting roses, 20

Plotting, 24.

Pomifera, Iog.

Portulaca, 25.

Powdery mildew, 30.

Premier, 76.

President Vignet, I 13.

Prima Donna (Mme. P Euler), 106, I 13.

Primula, 8o.

Prince Camille de Rohan, 59, 79, I06.

Prince Engelbert Charles d'Arenberg, I I3.

Prince de Bulgarie, I I3.

Prince of Wales, 88.

Princess Adelaide, I13.

Princess Bonnie, 113.

Princess de Sagan, I 4.

Princess Hohenzollern, I 14.

Prof. C. S. Sargent, I 15.

Protection for winter, 26-20.

Protecting tree roses, 29.

Provence, 108.

Prune, When to, 6, 7 .

Pruning, information, 31-35.

Pruning-shears, 35.

Psyche, II 5 .

Pyle, Robert, roo.

Queen Beatrice, II3.

Queen Mary, II3.

Queen Olga of Greece, I I 4.

Queens Scarlet, 59.

Queen, The, 106, I 14.

Radiance, $60,79,80,82,89$.

Rainbow, I 14.

Rambler, Crimson, I 5.

Ramblers, I I 5 .

Rayon d'Or, 6o.

Red Columbia, 76 .

Red-Letter Day, I I3.

Red Radiance, 60, 79, 83 .

Red Rose Church at Manheim, Ioo.

Regina Badet, I I 4 .

Reine Carola de Saxe, I 13. 
Reine Marguerite d'Italie, I13.

Reine Marie Henriette, I I 5 .

Rembrandt, I I I.

Rene Robbins, I 3 .

Renee Wilmart Urban, I 13.

Repens alba, I 14 .

Reve d'Or, II 5 .

Rhea Reid, I 13.

Richmond, I 13.

Robert Craig, I I 5 .

Robert Huey, 82.

Roger Lambelin, 60 .

Roosevelt, Ex - President Theodore; Io.

Rose-beads, I о I.

Rose-beetle, Spray for, 6.

Rose-bug, 30.

Rose-chafer, 30.

Rose-garden, The ama teur's, 3.

Rose-gardens, Famous, 27, 97, 98-100.

Rose-gardens, MunicipaI, 95-97.

Rose hedges, 74 .

Rose nicotine for aphis, 6 , 30.

Rose perfume, 102.

Rose progress, 93, 97.

Rose-slug, Spray for, 6, 30.

Rose test-gardens, 93.

Roses, Appropriate uses for, 4I, 42.

Roses, Attar of, ror.

Roses, Cemetery, 75.

Roses, Dependable varieties of, 43-62.

Roses, Establishing ideals, 5.

Roses, Forcing, 76.

Roses, How to arrange, 5.

Roses, Various uses of, 64-77.

Roses, Where to plant, 9.

Rose d'Evian, i 14 .

Roseraie de I'Hay, I I 4 .

Roseraie de I'Hay Rosegarden, 98-100.

Roseraie Parfum de I'Hay, I 14 :

Rubiginosa, 109.

Rubrifolia, 108.

Ruby Queen, 60.

Rugosa, I09.

Rugosa alba, 6o, 109.

Rugosa rubra, 60, 109.

Rust, 30.

Safrano, 60 .

St. Helena, 8r.

Salet, 113.

Santa Rosa, iro.

Sawdust Mulch, 25.

Scale, 30.

Scissors, Pruning, 35 .

Seabird, I 13.

Selecting the right roses, 37-4r.

Semperflorens, 108.
Sempervirens, 108.

Sericea, 109.

Sericeæ, 109.

Setigera, 108.

Shears, Pruning, 35.

Shower of Gold, 60 .

Silver Moon, 60.

Simplicifoliæ, 109.

Sinica, 109.

Sir Thomas Lipton, 6I.

Soap, Whale-oil, 30.

Sodenia, I I 5 .

Soils, 14.

Soleil d'Or, 6r

Solfatare, I 5 .

Sombreuil, I 14 .

South Orange Perfection, I I5.

Souv. de Catherine GuilIot, $\mathrm{I}$ I 4.

Souv. de E. Guillard, I 13.

Souv. de Gustave Prat, 6r, 89.

Souv. de Ia MaImaison, 6r.

Souv. de Pierre Leperdrieux, I I 4.

Souv. de P. Notting, 6r.

Souv. du President Carnot, 61.

Souv. de S. A. Prince, Io6.

Souv. of Wootton, I 13.

Souv. of Wootton, Climbing, I 15.

Species, 75.

Spectacular, II3.

Spinosissima, I 09

Spinosissimæ, r 09 .

Spray, When to, 6, 7 .

Standard roses, 13, 73.

Staking, 22.

Stiegel, Baron H. W., 100.

Stylosa, ro8.

Stylosæ, 108.

Suckers, 36.

Sulphur arsenate dust mixture, 7,30 .

Sulphurea, I 09, I 14.

Sunburst, 6I.

Sunrise, I I 4 .

Sunset, I 14.

Susanne-Marie Rodocanachi, 83.

Synonymous roses, 106.

Synstylæ, I08.

Sweetbriar, 6r.

Sweetheart, i 06, x 15.

Taft Rose, I I 3 .

Tausendschön, 6r, 83 .

Tea-scented, 108.

Temperature in different latitudes, 18.

Temple of Love, 99.

Test-gardens, 93.

Thalia, I 5 .

Thomas, Capt. George C., Yellow Soupert, I I4. Jr., 25.

Thousand Beauties, ro6.

Tip-Top, 6r.
Tomentosa, 109.

Tom Wood, 79, I II.

Totote Gelos, 79.

Tree roots, Danger from, 9.

Tree roses, 13, 73 .

Trier, I I 5 .

Triomphe Orleanais, 8o, I 44 .

Ulrich Brunner, 62 .

Universal Favorite, I 15 .

Van Fleet, Dr. W., 83.

Varieties, Number of, 37 .

Veluwezoom, I 13 .

Vick's Caprice, I I I.

Victor Verdier, I I I.

Villosa, rog.

Violas, 25.

Virginia R. Coxe, I06, I 13

Viridiflora, 62 .

Viscountess Enfield, I 13.

Viscountess Folkestone, 89 .

WaIter Speed, I 13.

Waltham's Scarlet, I 13.

Ward, Admiral Aaron, 8I.

War of the Roses, 63.

Wartburg, I I 5 .

W. C. Egan, i is.

Weeds, How to keep down, 25.

W. E. Lippiatt, I 13.

WeIlesley, I 13 .

West Grove, I 13.

White American Beauty, (Frau KarI Druschki), I 06.

White Killarney, 62.

White Killarney, Climbing, 115 .

White Maman Cochet, ${ }_{5} 6$, 80 .

White Maman Cochet, Climbing, i is.

White Soupert, 80, I I 4.

Wichmoss, ixs.

Wichuraiana, 62, 108 .

Wichuraiana variegata, I 5 .

Wm. Allen Richardson, 62.

Wm. Cooper, I 13.

Wm. R. Smith, 62, 83 .

William Shean, 62 .

Willowmere, 62, 79, 89 .

Winnie Davis, I 13 .

Winter Gem, I 4 .

Winter-protection, 27-20.

Winter-protection, When to remove, 27.

Wirth, Theodore, 29, 79.

Xanthina, rog.

York and Lancaster, 62, I 08 .

Yvonne Rabier, I 14 . 



\section{LIBRARY OF CONGRESS}

||||||||||||||||||||||||||||||||||||||||||||||||||

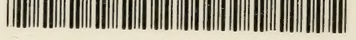

\section{4}

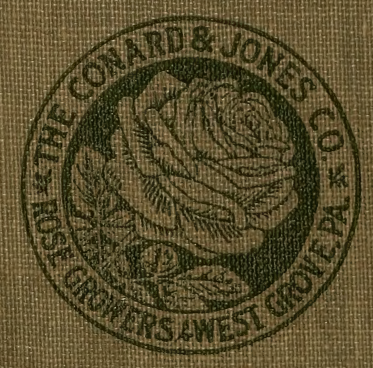

